University of Tulsa College of Law

TU Law Digital Commons

Articles, Chapters in Books and Other Contributions to Scholarly Works

1999

\title{
The Constitutionalization of Human Rights in Argentina: Problem or Promise?
}

Janet K. Levit

Follow this and additional works at: http://digitalcommons.law.utulsa.edu/fac_pub

Part of the International Law Commons

\section{Recommended Citation}

37 Colum. J. Transnat'l. L. 281 (1999).

This Article is brought to you for free and open access by TU Law Digital Commons. It has been accepted for inclusion in Articles, Chapters in Books and Other Contributions to Scholarly Works by an authorized administrator of TU Law Digital Commons. For more information, please contact daniel-bell@utulsa.edu. 


\title{
Articles
}

\section{The Constitutionalization of Human Rights in Argentina: Problem or Promise?}

\author{
JANET KOVEN LEVIT*
}

\begin{abstract}
Argentina incorporated several international human rights treaties into its Constitution in 1994, uniquely importing international law into its domestic legal system. While recent scholarship links internalization of international law to obedience, the Argentine experiment highlights that naked constitutionalization willnotnecessarily enhance compliance with international law. After analyzing the Constitutional Assembly's debates and the ensuing fate of the freshly constitutionalized human rights treaties in domestic courts, this Article concludes that the problems and the incipient promises of Argentina's constitutionalization experiment may be traced to the identity, enthusiasm, and cohesiveness of the transnational actors that coalesced to drive the internalization strategy. Furthermore, in countries like Argentina, where the rule of law is not firmly anchored, an internalization strategy that centers on law, and law alone, is unlikely to succeed. A successful internalization strategy must be a dynamic, multifaceted process that engages a myriad of transnational actors from social, political, as well as legal, spheres.
\end{abstract}

* Assistant Professor of Law, University of Tulsa College of Law (on leave 1998-1999). Attorney Advisor, Export-Import Bank of the United States. A.B., Princeton University, 1990; M.A., Yale Graduate School, 1994; J.D., Yale Law School, 1994. The Author wishes to thank the University of Tulsa College of Law for its financial support of this project. The Author is grateful to Martín Abregú, Martin Böhmer, Carlos Rosenkrantz, and Roberto Saba for helping in the collection of Argentine sources. The Author sends thanks to Professor Harold Koh and Professor Michael Reisman for sparking my interest in human rights. The Author sends special thanks to Professor Robert Burt and Professor Owen Fiss for inspiring this piece and fueling my interest in Argentina. Finally, to my husband, Kenny Levit, thank you for pushing me to finish this piece; and to my son, Nathan, thank you for filling my days and nights with smiles. 
I. INTRODUCTION . . . . . . . . . . . . . . . . . . . 282

II. COMPLIANCE, OBEDIENCE AND TRANSNATIONAL LEGAL Process . . . . . . . . . . . . . . . . . . 283

III. Constitutionalization OF HUMAN Rights in ARgentina: THE CONTEXT . . . . . . . . . . . . . . . . . 287

A. Argentina's Constitutional Reform ........... 287

B. Human Rights and South American Constitutions ... 292

1. Substantive Incorporation of Human Rights Norms .. 293

2. Constitutional Status of Human Rights Norms ..... 301

C. Argentina's Constitution in Context: Pre-1994 .... 306

1. Constitutional Status of Human Rights . . . . . . . 306

2. Substantive Treatment of Human Rights ...... 309

D. Argentina's 1994 Constitution .............. 310

IV. ASSESSING THE INTERNALIZATION STRATEGY:

A SCOREBOARD ..................... 313

A. The Problems ....................... 314

1. The Constitutional Assembly: Where are the Transnational Actors? . . . . . . . . . . . . . . . 314

a. The Constitutional Assembly: the Prologue ... 315

b. The Constitutional Assembly Proceedings ...... 316

2. The Domestic Courts in the Wake of the

Constitutional Assembly: Passive Transnational Actors 324

a. The Supreme Court ................ 324

b. Lower Court Decisions ............... 327

3. Transnational Actors in Potential Conflict: Argentina's

Legal System v. Inter-American Human Rights System 329

B. The Promises .................... 334

1. Unlikely Bedfellows: Potential Transnational Actors . 335

2. Mobilization of Key Transnational Actors: The NGOs . . . . . . . . . . . . . . . . . 337

3. Empowering Transnational Actors: The Individual .. 341

V. IMPLICATIONS FOR TRANSNATIONAL LEGAL PROCESS:

THE LIMTTS OF THE LAW . . . . . . . . . . . . . . 343

\section{INTRODUCTION}

International law is as potent as nations' proclivities to obey. For hundreds of years, international relations and legal scholars have asked why nations follow international norms. Recent scholarship recognizes 
that internalization, or domestication, of international norms enhances compliance. While the internalization of international law is international legal scholars' vogue mantra, these scholars have not delved sufficiently into the process by which international law is drawn into domestic systems. This Article will use a recent experiment in internalization of international law as a window into its process and limits.

Unlike many Latin American constitutions, the core of Argentina's Constitution had not been significantly altered since 1853. As part of the democratization process following the military dictatorship, Argentina engaged in a major constitutional reform effort, incorporating, by reference, nine prominent human rights treaties into its Constitution. Thus, Argentina presents scholars with an ostensibly prototypical example of legal internalization-internalization of international law via constitutionalization.

Argentina's Constitution provides a glimpse at the dynamic process by which nations internalize international norms. Argentina's experiment, while young, has thus far produced rather limited results in terms of compliance because it failed to empower, mobilize, and create synergistic relationships among a diverse panoply of transnational actors -individuals, politicians, non-governmental organizations ("NGOs"), governmental entities and supranational bodies-that straddle Argentina's legal, political and social spheres. Thus, the problems and the promise of Argentina's constitutionalization experiment may be traced to the identity, enthusiasm, and cohesiveness of the transnational actors that coalesced to drive Argentina's internalization strategy.

\section{COMPLIANCE, Obedience AND TRANSNATIONAL LEgAL PROCESS}

Internationalists in the legal community as well as the political science community have long searched for answers to the "compliance question"- - why do nations comply with international law?- and its derivatives: if we understand why nations comply with international law, can we predict when they will comply and when they will disregard international law? Or, can we structure rules and/or political relationships that maximize compliance?

While the international law theoretical landscape evolved significantly during the postwar years, the search for an answer to the "compliance question" remained a constant thread. Classic rationalists believe that nations comply with international law when the perceived 
benefits outweigh the perceived costs. ${ }^{1}$ Rationalists have refined their approaches, creating sophisticated game theory-inspired models rearticulating their time-worn proposition: states abide by international law when it is in their self-interest to do so. ${ }^{2}$ The New Haven School links compliance to a communicative process of authoritative decisionmaking on a domestic level which strives to maintain a world public order of "human dignity."3 Regime theorists link compliance to dispute-settlement mechanisms, information gathering mechanisms, and concomitant retaliatory actions. ${ }^{4}$ Liberal theorists link compliance to "liberal" political and economic structures. ${ }^{5}$ Liberal states and

1. Rationalists, sometimes referred to as interest theorists, believe that states comply with international law when it suits their interests, primarily defined in terms of wealth and power. The theory is systemic, resting on nation-states as the primary actors, and has been used extensively in the arms control and trade contexts. For the classic rationalist approach, see generally LOUIS HENKIN, HOW NATIONS BEHAVE (2d ed. 1979).

2. For modern examples of the rationalist approach, see generally John K. Setear, $A n$ Iterative Perspective on Treaties: A Synthesis of International Relations Theory and International Law, 37 HARV. INT'L L.J. 139, 142-47 (1996); Kenneth W. Abbott, 'Trust but Verify': The Production of Information in Arms Control Treaties and Other International Agreements, 26 CORNELL INT'L L.J. 1 (1993); Kenneth W. Abbott, Modern International Relations Theory: A Prospectus for International Lawyers, 14 YALE J. INT'L L. 335 (1989); Kenneth W. Abbott, The Trading Nation's Dilemma: The Functions of the Law of International Trade, 26 HARV. INT'L L.J. 501 (1985); Duncan Snidal, Coordination Versus Prisoner's Dilemma: Implications for International Cooperation and Regimes, 79 AM. POL SCI. REV. 923 (1985); Duncan Snidal, The Game Theory of International Politics, 38 WORLDPOL. 226(1985).

3. See Myres S. MCDougal, International Law, Power, and Policy: A CONTEMPORARY CONCEPTION 8 (1954); W. Michael Reisman, International Lawmaking: A Process of Communication, 75 AM. SOC'Y INT'L L. PROC. 101, 107, 113 (1981) (describing the New Haven School as a "communications model" which sees the legal process as comprising three communicative streams - "policy content, authority signal and control intention"-which thereby "liberates the inquirer from the ... distorting model of positivism, which holds that law is made by the legislature," in favor of the notion that "any communication between elites and politically relevant groups which shapes wide expectations about appropriate future behavior must be considered as functional lawmaking."). See generally Richard A. Falk, Casting the Spell: The New Haven School of International Law, 104 YALE L.J. 1991 (1995); Symposium, McDougal's Jurisprudence: Utility, Influence, Controversy, 79 AM. SOC'Y INT'L L. PROC. 266 (1985) (remarks of Oscar Schacter); Myres S. McDougal \& W. Michael Reisman, The World Constitutive Process of Authoritative Decision, 19 J.LEGALEDUC. 253 (1967). For an excellent description of the New Haven School, see Anne-Marie Slaughter Burley, International Law and International Relations Theory: A Dual Agenda, 87 AM. J. INT'L L. 205, 209-11 (1993) [hereinafter A Dual Agenda].

4. See generally ORAN R. YOUNG, INTERNATIONAL COOPERATION: BUILDING REgIMES FOR NATURALRESOURCES ANDTHEENVIRONMENT (1989); Robert M. Axelrod, An Evolutionary Approach to Norms, 80 AM. POL. SCI. REV. 1095 (1986); ROBERT O. KEOHANE, JR., AFTER HEGEMONY: COOPERATION AND DISCORD IN THE WORLD POLITICALECONOMY (1984); ROBERT M. AXELROD, THE EVOLUTION OF COOPERATION (1984); ORAN R. YOUNG, COMPLIANCE AND PUBLIC AUTHORITY: A THEORY WITH INTERNATIONAL APPLICATIONS (1979).

5. See Anne-Marie Slaughter, International Law in a World of Liberal States, 6 EUR. J. INT'LL. 503, 511 (1995) [hereinafter International Law: Liberal States]. See generally A Dual Agenda, supra note 3; Anne-Marie Burley, Law Among Liberal States: Liberal Internationalism and the Act of State Doctrine, 92 CoLUM.L. REv. 1907 (1992). Liberal theorists are sometimes referred to as "identity" theorists. 
transnational actors therein comply with international agreements with other liberal states because of a mutual perception that liberal legal structures, primarily an independent judiciary, will foster compliance and constrain deviation from an international norm. ${ }^{6}$ International society theorists believe that the "norms, values, and social structure of international society"7 condition compliance, particularly because transnational actors have a "longer-term interest in the maintenance of law-impregnated international community."8

Professor Harold Koh, in a recent series of articles, ${ }^{9}$ asks a slightly more nuanced and robust question - why do nations obey (rather than comply with) international law ${ }^{10}$ The difference between compliance and obedience is rather subtle. Compliance is norm-conforming behavior conditioned by exogenous forces, that is, the desire to reap certain benefits or avoid punishment; ${ }^{11}$ while obedience is endogenous, the voluntary accession to a norm incorporated into internal value systems. Compliance is contingent, dependent on the consequences of non-compliance (I will comply because I want X or do not want $\mathrm{Y}$ ), while obedience is a non-contingent embodiment of a rule or a norm. While compliance may be begrudging, obedience is habitual, almost instinctual. Through obedience, international norms become an embedded part of a nation's legal fabric. ${ }^{12}$

Then, how do nations come to obey, rather than merely comply with, international law? Koh's answer: transnational legal process. ${ }^{13}$

6. See International Law: Liberal States, supra note 5, at 532-33. See generally A Dual Agenda, supra note 3.

7. Harold Hongju Koh, Why Do Nations Obey International Law?, 106 YALE L.J. 2599, 2634 (1997) (reviewing ABRAM CHAYES \& ANTONIA HANDLER CHAYES, THE NEW SOVEREIGNTY:COMPLIANCE WITHINTERNATIONALREGULATORY AGREEMENTS (1995); THOMAS M. FRANCK, FAIRNESS IN INTERNATIONAL LAW (1995)).

8. Id. (quoting Andrew Hurrell, International Society and the Study of Regimes: A Reflective Approach, in REGIME THEORY AND INTERNATIONAL RELATIONS 49, 59 (Volker Rittberger ed., 1993)).

9. See generally Koh, supra note 7; Harold Hongju Koh, Transnational Legal Process, 75 NEB. L. REV. 18 (1996).

10. See Koh, supra note 7, at 2603 \& n.13; see generally SECURING COMPLIANCE: SEVEN CASE STUdies (Martin L. Friedland ed., 1990).

11. See, e.g., Charles O'Reilly III \& Jennifer Chatman, Organizational Commitment and Psychological Attachment: The Effects of Compliance, Identification, and Internalization on Prosocial Behavior, 71 J. APPL'D PSYCHOL. 492, 493 (1986) (noting that compliance is "instrumental involvement for specific, extrinsic rewards").

12. See Koh, supra note 7, at 2654.

13. Koh admits that transnational legal process presents little that is new. See id. at 2659 ("This Review Essay has demonstrated that, far from being novel, domestic obedience to internalized global law has venerable historical roots and sound theoretical footing."). Koh recognizes that transnational legal process is the descendant of the International Legal Process movement. See id. at 2620-24 (discussing the International Legal Process School and the New Haven School as predecessors to transnational legal process). Koh also recognizes that Henry 
Transnational legal process links obedience to a complex, multidimensional process of interaction, interpretation and internalization. ${ }^{14}$ Like many modern international legal theorists, Koh recognizes that states do not constitute the universe of transnational actors-individuals, corporations, non-governmental entities, publicinterest organizations, sub-governmental entities, regional organizations, and international bodies play decisive roles in transnational legal processes. ${ }^{15}$ These transnational actors are the engines of compliance, and later, obedience. According to Koh, transnational legal process involves three integrally-intertwined sub-processes: 1) interaction among transnational actors generates international norms; 2) further interaction in national and supranational fora leads to interpretation of norms; and 3) concomitant internalization of international norms into domestic legal systems results in compliance and, if the internalization strategy is effective, ultimate obedience. ${ }^{16}$ Transnational actors' repeated norm-producing interaction and norm-illuminating interpretations foster entrenchment of international law into domestic legal systems, causing international norms to become "sticky" and ultimately breeding not mere compliance, but rather, habitual

Steiner and Detlev Vagts pioneered the study of transnational legal process. See id. at 2626 (discussing HENRY STEINER \& DETLEV VAGTS, TRANSNATIONAL LEGALPROBLEMS (1968) (now HENRY STEINER, DETLEV VAGTS \& HAROLD HONGJU KOH, TRANSNATIONAL LEGAL PROBLEMS (4th ed. 1994)). He further admits that transnational legal process is an amalgamation of several strands of international legal theory: (1) interest [see supra notes 1-2 and accompanying text]; (2) identity [see supra notes 5-6 and accompanying text]; (3) constructivist [(constructivists believe that international norms play a significant constitutive role in defining national interests and identities) (see Ngaire Woods, The Uses of Theory in the Study of International Relations, in EXPLAINING INTERNATIONAL RELATIONS SINCE 1945, at 26 (Ngaire Woods ed., 1996); Alexander Wendt, Constructing International Politics, 20 INT'L SECURITY 71 (1995); Alexander Wendt, Collective Identity Formation and the International State, 88 AM. POL. SCI. REV. 384 (1994))]; and (4) international society [see supra notes 7-8 and accompanying text]. Yet, for Koh, these roots strengthen, rather than diminish, the theoretical value of transnational legal process. See Koh, supra note 7, at 2634.

14. See Koh, supra note 7, at 2645-58.

15. See id. at 2626 (transnational actors include "nation-states, international organizations, multinational enterprises, nongovernmental organizations, and private individuals ...").

16. See id. at 2602-03, 2646 ("[Transnational legal process] can be viewed as having three phases. One or more transnational actors provokes an interaction (or series of interactions) with another, which forces an interpretation or enunciation of the global norm applicable to the situation. By so doing, the moving party seeks not simply to coerce the other party, but to internalize the new interpretation of the international norm into the other party's internal normative system. The aim is to 'bind' that other party to obey the interpretation as part of its internal value set .... The transaction generates a legal rule which will guide future transnational interactions between the parties; future transactions will further internalize those norms; and eventually, repeated participation in the process will help to reconstitute the interests and even the identities of the participants in the process.").

Koh explores isolated examples of "transnational legal process" in action. For Koh's discussion of the Anti-Ballistic Missile Treaty Reinterpretation Debate, see id. at 2646-48. For his discussion of the Middle East peace process, see id. at 2651-54. For his discussion of the Haitian refugee interdiction policy, see Koh, supra note 9, at 196-99. 
obedience. ${ }^{17}$ Thus, transnational legal process is a robust theory that emanates descriptive, prescriptive, and predictive energy.

While the ultimate bridge to obedience is internalization of international law, transnational legal process envisions internalization processes that are necessarily fluid, loosely defined by transnational actors' interests, which may respond to and be reconstituted as a result of transnational processes. In his work, Koh suggests that internalization strategies may involve social,,${ }^{18}$ political, ${ }^{19}$ and/or legal ${ }^{20}$ mechanisms; he also offers several illustrative glimpses of these internalization processes at work. ${ }^{21}$ Yet for all of its energy and all of its dynamism, transnational legal process theory's treatment of its crucial and defining link -international law's penetration into domestic systems-is rather thin. Transnational legal process thus beckons scholars to take a deep, exploratory dive into the dynamics of internalization processes or, as Koh phrases it, the nature of the "transmission belt." 22 Koh implicitly admits this, concluding his piece with a plea to the international legal and scholarly communities to develop strategies for internalization. ${ }^{23}$ This Article, which explores one particular internalization strategy-internalization via constitutionalization-is a response to his plea.

\section{Constitutionalization of Human Rights in Argentina: The CONTEXT}

\section{A. Argentina's Constitutional Reform}

Unlike many Latin American constitutions, Argentina's Constitution was a portrait of longevity, dating from $1853 .{ }^{24}$

17. See Koh, supra note 7 , at $2646,2649,2651,2655$.

18. See id. at 2656 ("Social internalization occurs when a norm acquires so much public legitimacy that there is widespread general obedience to it.").

19. See id. at 2656-57 ("Political internalization occurs when political elites accept an international norm, and adopt it as a matter of government policy.").

20. See id. at 2657 ("Legal internalization occurs when an international norm is incorporated into the domestic legal system through executive action, judicial interpretation, legislative action, or some combination of the three.").

21. See supra note 16 and accompanying text.

22. Koh, supra note 7, at 2651.

23. See id. at 2656-59.

24. See CONST. ARG. (1853) 9-49 (Editorial Universidad, 1990) (translations of the 1853 Argentine Constitution are by the Author). Although the core of Argentina's Constitution has remained constant since 1853, there have been several amendments since 1853. For example, in 1860 the Convención Nacional bolstered the powers of the federal government vis-à-vis the provinces, abolished slavery, and limited the government's power to restrict individual liberties, including freedom of the press; in 1866 the Convención Nacional constitutionalized several federal taxes; in 1898 the Convención Nacional changed the representation in the Cámara de 
Argentina's Constitution largely echoed the U. S. Constitution, especially regarding separation of powers and federalism. ${ }^{25}$ The 1853 Constitution did not explicitly address human rights treaties, or even international law in general. Like the U.S. Constitution, the 1853 Constitution divided power over international treaties among the three independent branches: "The Congress shall approve or disapprove of treaties concluded with other nations"; ${ }^{26}$ the Executive shall conclude and sign treaties with foreign powers and receive their ministers $;{ }^{27}$ and the federal courts shall have jurisdiction over matters pertaining to international treaties. ${ }^{28}$

From 1976 through 1983, Argentina suffered a brutal military dictatorship, during which thousands "disappeared."29 These severe

Diputados (House of Representatives); and in 1957 the Convención Nacional added a provision that enhanced the rights of workers. See id. at 55-67. See also Larry Rohter, In Latin America, 'The Constitution is What I Say It Is,' N.Y. TMES, Aug. 30, 1998, at 1 (noting the tendency of many Latin American countries to edit their constitutions frequently).

25. See CONST. ARG. (1853) at 22-49 (Second Part: National Authority). In fact, the Argentine Supreme Court frequently cites U.S. Supreme Court decisions as authoritative. See generally Jonathan M. Miller, Judicial Review and Constitutional Stability: A Sociology of the U.S. Model and its Collapse in Argentina, 21 HASTINGS INT'L \& COMP. L. REV. 77 (1997); Jonathan M. Miller, The Authority of a Foreign Talisman: A Study of U.S. Constitutional Practice as Authority in Nineteenth Century Argentina and the Argentine Elite's Leap of Faith, 46 AM. U. L. REv. 1483 (1997).

26. CONST. ARG. (1853) art. 67(19).

27. See CONST. ARG. (1853) art. 86(14) (the President shall have the power to "conclude and sign treaties regarding peace, commerce, navigation, alliance, neutrality, accords, and other negotiations required for the maintenance of good relations with foreign powers, as well as receive their ministers and admit their consuls.").

28. See CONST. ARG. (1853) art. 100 ("The Supreme Court and the inferior federal tribunals shall have jurisdiction over all causes of action regarding ... treaties with foreign nations.").

29. Following violence and political polarization that occurred during the mid-1970's, a junta of military dictators-General Videla, Admiral Massera, and Brigadier Agosti-took control of Argentina's government. Engaged in a war against "subversion" and in the name of "national security," the junta suspended civil liberties and imposed a state of siege. See CARLOS SANTIAGONINO, RADICALEVILONTRIAL 53-54 (1996). National security forces abducted those who were engaged in "subversive" activities, brought them to clandestine detention centers, tortured and interrogated them, and frequently killed them. See id. at 54. Recent confessions on the part of ex-military officials reveal that the military threw many prisoners from airplanes over the Atlantic Ocean. See Laurie Goering, Argentine 'Dirty War' Informer Vilified: Ex-Navy Officer Details Killings in '70s Oppression, CHI. TRIB., Dec. 7, 1997, at 6. For a haunting discussion of the modus operandi of the military, including a description of torture techniques and detention centers, see COMISIÓN NACIONAL SOBRE LA DESAPARACIÓN DE PERSONAS (CONADEP), NUNCA MAS (1985) (truth commission's accounting of dirty war atrocities). While the official estimates are that 10,000 "disappeared," most human rights groups believe that the number is closer to 30,000. See Argentina to Release List of 'Disappeared,' Human Rights Groups Call for More Details from 1970s 'Dirty War,' CHI. TRIB., Mar. 26, 1995, at 10; David Chrieberg, 'I Can't Erase This,' NEwSWEEK, Mar. 27, 1995, at 38.

The military dictatorship remained strong from 1976 to 1980 , but began to falter thereafter for several reasons. First, the Inter-American Commission on Human Rights, coupled with the pro-human rights stance of President Jimmy Carter, turned international opinion against the military dictatorship. See NINO, supra, at 60. Second, Britain defeated Argentina's 
human rights abuses were the backdrop to subsequent democratization efforts and, ultimately, the 1994 constitutional reform. When President Raúl Alfonsín, a member of the Radical Party, ushered in democracy in the wake of the military dictatorship, he promised to fight human rights abuses prospectively, principally through prophylactic legislative action. ${ }^{30}$ Toward this end, he convoked El Consejo para la Consolidación de la Democracia (the Advisory Commission for the Consolidation of Democracy, or Advisory Commission) ${ }^{31}$ and included in the group's charge a study of a major constitutional reform initiative. ${ }^{32}$ After extensive consideration, the Advisory Commission recommended that the President convene a Constitutional Assembly to undertake the first comprehensive constitutional reform since 1853 and highlighted several substantive issues for reform. ${ }^{33}$ With regard to human rights, the Advisory Commission implored any constitutional assembly to "amplify and strengthen" individual rights and, under no circumstances, diminish or limit such rights. ${ }^{34}$ The Advisory

military with great speed and ease during the Falklands War, thus discrediting Argentina's military. See id. at 60-61. Third, non-governmental organizations, most prominently the Madres de Plaza de Mayo, began to publicize the disappearances. See id. at 59. Fourth, the economy declined. See id. at 60 .

There is a vast literature on Argentina's military dictatorship, referred to as the "dirty war." For a representative sample, see NINO, supra, at 41-104 (describing Argentina's history, from the dirty war through democratization); ALISON BRYSK, THE POLITICS OF HUMAN RIGHTS IN ARgentina: Protest, Change, and DEMOCRATIZation (1994); MARTIN E. ANDERSON, DOSSIER SECRETO: ARGENTINA'S DESAPARECIDOS ANDTHE MYTHOFTHE“DIRTYWAR"(1993); IAIN GUEST, BEHIND THEDISAPPEARANCES: ARGENTINA'S DIRTY WAR AGAINST HUMANRIGHTS ANDTHE UNITED NATIONS (1990); Alejandro M. Garro, Nine Years of Transition to Democracy in Argentina: Partial Failure or Qualified Success?, 31 COLUM. J. TRANSNAT'L L. 1 (1993); Carlos S. Nino, The Duty to Punish Past Abuses of Human Rights Put Into Context: The Case of Argentina, 100 YALE L. J. 2619 (1991); LAWRENCE WESCHLER, A MIRACLE, A UNIVERSE: SETTLING ACCOUNTS WITH TORTURERS (1990).

30. See NINO, supra note 29, at 67-73. President Alfonsín also attempted to impose "retroactive justice" through domestic criminal trials of the military junta. For a description and assessment of these trials, see generally $i d$. President Menem ultimately pardoned all those who were convicted in these trials. See id. at 103-04.

31. See EdToRial Universitaria de Buenos Aires, Reforma Constitucional: DICTAMEN PRELIMINAR DEL CONSEJO PARA LA CONSOLIDACIÓN DE LA DEMOCRACIA 7 (1986).

32. See id. at 8, 13-14.

33. The Advisory Commission believed such reform was necessary for the following reasons: 1 ) the executive had neutralized or nullified the effects of prior reform (amendment) efforts; 2) structural and substantive constitutional defects had limited the previous Constitution's force and effectiveness; 3 ) the political philosophies upon which the original Constitution rested had shifted; 4 ) while there was robust political debate on many issues, there was broad social consensus regarding the need for structural reform in the wake of the dictatorship; and 5) while some argued that the constitutional reform effort should await a period of calm, the Advisory Commission believed that some of the most profound constitutional moments followed a period of significant unrest and upheaval. See id. at 23-30.

34. Id. at 39 (noting in particular that the following articles of the 1853 Argentine Constitution should not be limited or circumscribed: Article 14 (rights of labor); Article 15 (abolition of slavery and the prohibition thereof); Article 16 (abolishing nobility); Article 19 (right to privacy); and Article 20 (equal rights of foreigners)). 
Commission made several suggestions regarding the constitutional status of international law: 1) grant Congress the power to delegate certain functions to supranational entities; 2) make all international treaties self-executing ${ }^{35}$ upon congressional ratification; and 3) establish the superiority of international treaties over domestic law. ${ }^{36}$

Despite the meticulous and painstaking work of the Advisory Commission, the constitutional reform project languished with the Alfonsín government. ${ }^{37}$ The reform project was not to be revived until 1993, when, following extreme animosity and partisanship between President Menem (the Peronist Party) and the discredited Radical Party, the two camps agreed to proceed with the constitutional reform. ${ }^{38}$ The public viewed the agreement, known as the "Pacto de Olivos," as shrouded in a cloak of partisan suspicion, seeing it as a mere opportunity for the Peronists to consolidate and extend their power and for the Radical Party to create an institutional and programmatic space for themselves in the wake of its discredited government. ${ }^{39}$ The ensuing law divided the substantive reform effort into two components: a nucleus of mandatory reforms ${ }^{40}$ and a peripheral group of themes for possible consideration. ${ }^{41}$ Congress did not include human rights per se

35. A self-executing treaty is one that is enforceable law without enabling legislation. Likewise, a non-self-executing treaty is unenforceable absent legislative action. See RESTATEMENT (THIRD) OFTHE FOREIGN RELATIONS LAW OFTHE UNITED STATES § 111 (1986) [hereinafter RESTATEMENT].

36. See EDITORIAL UNIVERSITARIA DE BUENOS AIRES, supra note 31, at 82-83.

37. President Alfonsín's constitutional reform efforts were impeded by an economic crisis due to such factors as an inflated public sector and massive foreign debt. See Lita Olbrich, Only Economic Restructuring Can Save Argentina, DALLAS MORNING NEWS, July 16, 1989, at 31A. Nevertheless, Alfonsin remained tireless in his efforts to consolidate democracy. See generally NINO, supra note 29, at 99-104. In addition to the severe military crisis, President Alfonsín faced threats of military coup and political unrest. See id. at 90-104; Jill Smolowe, Caught in a Revolving Door: Alfonsin's State of Siege is Hobbled by the Courts, TME, Nov. 11, 1995, at 53.

38. President Menem hoped to amend the Constitution to enable him to remain in office beyond the constitutionally circumscribed term. In exchange for Radical Party (Alfonsín) support for this amendment, President Menem agreed to comprehensive constitutional reform. See Christopher M. Nelson, An Opportunity for Constitutional Reform in Argentina: ReElection 1995, 25 U. MiAMI INTER-AM L. Rev.283, 294 (1994); Juan C. Vega, Contexto Social y Político de la Reforma Constitucional de 1994 in JERARQUía CONSTITUCIONAL DE LOS TRATADOS INTERNACIONALES 1, 2-3 (Juan Carlos Vega \& Marisa Adriana Graham eds., 1996) (translations by the Author). The text of the agreement became Law No. 24,309 (on file with Author). See also infra notes $165-70$ and accompanying text.

39. See VEGA, supra note 38 , at $2-5$.

40. This nucleus included the following issues: Presidential reelection; reduction of the Presidential term to four years; lengthening of the annual legislative session; direct election of the Mayor of Buenos Aires; limitation on the President's power to act via executive decree; and auditing of the federal coffers. See id. at 9-10.

41. The list of peripheral themes included: strengthening of the federal government; municipal autonomy; popular initiatives and consultations; updating of Congressional and Executive functions; investigative and enforcement powers of Congress; institutions dealing 
in either group, although it included issues concerning international treaties in the latter and created a committee within the Constitutional Assembly, the Comisión de Integración y Tratados Internacionales (Commission on Integration and International Treaties, or Treaty Commission), to study the status of international treaties and create mechanisms to further regional integration efforts. ${ }^{42}$

While post-1994 provisions regarding executive and judicial power vis-à-vis international treaties remained highly reminiscent of the 1853 Constitution, ${ }^{43}$ Article $75(22)$ of the 1994 Constitution, ostensibly concerning legislative powers, dramatically altered the Argentine Constitution's substantive treatment of human rights, as well as the legal status of international human rights treaties. The new provision specifies the following: 1) Congress will approve or reject treaties concluded with other nations, with international organizations, and with the Holy See; 2) all international treaties (currently ratified, as well as those that Argentina may ratify in the future) are superior to domestic laws; 3) several human rights treaties enjoy constitutional status; ${ }^{44} 4$ ) none of these treaties may limit any of the rights granted in the first part of the Constitution; ${ }^{45}$ ) human rights treaties may be renounced by the

with integration and international treaties; the defense of democracy; the preservation of the environment; an executive commission to investigate economic/social issues; indigenous communities; consumer rights; and habeas corpus/direct constitutional appeals. See id. at 10.

42. See id. at 11-12.

43. See supra notes 26-28 and accompanying text. See also CoNST. ARG. (1994). Article 99(11) regarding executive power over international treaties in the 1994 Constitution is similar to Article 86(14) in the 1853 Constitution. Article 116 regarding judicial power over international treaties in the 1994 Constitution is identical to Article 100 in the 1853 version.

44. The following treaties have constitutional standing: American Declaration of the Rights and Duties of Man, signed May 2, 1948, OEA/Ser.L./N./I.4, rev. 6 (1965); American Convention on Human Rights, Nov. 22, 1969, 9 I.L.M. 673 (1970) [hereinafter American Convention]; Universal Declaration of Human Rights, adopted Dec. 10, 1948, G.A. Res. 217(III)A, U.N. Doc. A/810, at 71 [hereinafter Universal Declaration]; International Covenant on Economic, Social, and Political Rights, concluded Dec. 16, 1996, 993 U.N.T.S. 4 (entered into force Jan. 3, 1976); International Covenant on Civil and Political Rights, concluded Dec. 16, 1966, 999 U.N.T.S. 171 (entered into force Mar. 3, 1976) [hereinafter International Covenant]; Optional Protocol to the International Covenant on Civil and Political Rights, concluded Dec. 16, 1966, 999 U.N.T.S. 171, 302 (entered into force Mar. 23, 1976); Convention on the Prevention and Punishment of the Crime of Genocide, concluded Dec. 9, 1948, 78 U.N.T.S. 227 (entered into force Jan. 12, 1951); International Convention on the Elimination of All Forms of Racial Discrimination, concluded Dec. 21, 1965, 660 U.N.T.S. 195 (entered into force Jan. 4, 1969); Convention on the Elimination of All Forms of Discrimination Against Women, concluded Dec. 18, 1979, 1249 U.N.T.S. 13 (entered into force Jan. 4, 1969); Convention Against Torture and Other Cruel, Inhuman, Degrading Treatment or Punishment, G.A. Res. 39/46, Annex, U.N. GAOR, 39th Sess., Supp. No. 15, at 197, U.N. Doc. A/39/51 (1985); Convention on the Rights of the Child, G.A. Res. 44/25, Annex, U.N. GAOR, 44th Sess., Supp. No. 49, at 166, U.N. Doc. A/44/49 (1990).

All other international treaties are superior to domestic statutes but inferior to the Constitution. See infra notes 181-84 and accompanying text.

45. See CONST. ARG.(1994) arts. 1-42 (Declarations, Rights, and Guarantees; New Rights and Guarantees). 
executive, with the prior approval of two-thirds of both houses of the legislature, a procedure similar to that required for constitutional amendments; ${ }^{46}$ and 6 ) other human rights treaties and conventions, approved by Congress, require a two-thirds vote of both houses of the legislature in order to endow them with constitutional standing. ${ }^{47}$ The Constitutional Assembly also included a new provision promoting regional integration. ${ }^{48}$

\section{B. Human Rights and South American Constitutions}

As the following perusal of South American constitutions ${ }^{49}$ demonstrates, Argentina's constitutionalization of human rights was a unique development in the region. Substantively, while international human rights norms infiltrate national constitutions to greater or lesser degrees, Argentina's Constitution is a unique, verbatim replica of these treaties. In terms of status, Argentina is the only country that grants human rights treaties constitutional standing. The following section groups South American constitutions along these two comparative axes - substance and status-illustrating that Argentina's Constitution is a lone outlier. This section merely attempts to classify constitutions vis-àvis their treatment of international human rights norms and/or treaties; it does not assess the relative effectiveness of different constitutional approaches in the protection of human rights.

46. See id. art. 30. (setting forth the procedures for amending the Constitution: "The Constitution may be amended entirely or in any of its parts. The necessity of amendment must be declared by the Congress by a vote of at least two-thirds of the members; but it shall not be effected except by a convention called for the purpose.").

47. For the full text of Article 75(22), see CONST. ARG. (1994).

48. See CONST. ARG. (1994) art. 75(24) (Congress shall have the power to "approve integration treaties which delegate competences and jurisdiction to interstate organizations concerned with reciprocal and equal conditions and which respect the democratic order and human rights. Any standards dictated pursuant thereto supersede the laws."). See also infra note 243 and accompanying text.

49. This Author chooses to limit her comparison to South American constitutions for the following reasons: 1) most, if not all, have been rewritten, or significantly revised in the postWorld War II period; 2) the region has shared a recent history of human rights abuses and thus shares a desire to combat future human rights abuses; and 3) the geographical and cultural proximity to Argentina. 


\section{Substantive Incorporation of Human Rights Norms}

Many modern constitutions ${ }^{50}$ incorporate human rights norms, borrowing from international and regional human rights treaties. While many human rights treaties could serve as comparative reference points, this Article selects the International Covenant on Civil and Political Rights (the "International Covenant") ${ }^{51}$ and the American Convention on Human Rights (the "American Convention") ${ }^{52}$ because they comprehensively attempt to address and redress the most heinous of the civil and political rights abuses that became commonplace in South America during the military dictatorships. ${ }^{53}$

50. For human rights purposes, a modern constitution is one that post-dates World War II; for prior to World War II, international law did not recognize the human being-the individual - as an international actor who bears international rights. See LOUIS HENKIN, THE RIGHTS OFMAN TODAY 18 (1978); IAN BROWNLIE, PRINCIPLES OFPUBLIC INTERNATIONAL LAW 323-45 (4th ed. 1990); Steven R. Ratner, The Schizophrenias of International Criminal Law, 33 TEX. INT'LL.J. 237, 242 (1998); Tom Farer, Introduction to INTER-AMERICAN COMMISSION ON HUMAN RIGHTS: TEN YEARS OF ACTIVITIES 1971-1981 v-vi (1982). See also The London Charter, Charter of the International Military Tribunal (IMT), Agreement for the Prosecution and Punishment of the Major War Criminals of the European Axis, Aug. 8, 1945, 58 Stat. 1544, 82 U.N.T.S. 280. The London Charter is the document that constituted the Nuremberg Tribunal, christened the modem human rights era, and delineated the causes of action for which the allies intended to try the Nazi defendants, including crimes against humanity-"murder, extermination, enslavement, or any other inhumane act committed against any civilian population before or during the war, as well as persecution based on political, religious, or racial grounds ... regardless of whether the accused had violated the domestic law of the countries where the deeds had been committed." Id. art. 6. Through its definition of crimes against humanity, the London Charter recognized and legitimized the two salient features of modern international human rights law: 1) the individual is the beneficiary of the rights; and 2) certain rights are universal, superior to the dictates of national law.

Also following World War II, the international community joined to create an international body, the United Nations, that would presumably forestall the type of international "meltdown" that had ripened into such a devastating war. The United Nations Charter lists promotion of and respect for "human rights and for fundamental freedoms" among its primary animating purposes. U.N. CHARTER art. 1, para. 1. Beyond flagging human rights as a preeminent concern, the Charter did not specifically contemplate any substantive rights. Instead, the United Nations General Assembly adopted the Universal Declaration, providing all individuals with the rights to equality; life; liberty; travel; privacy; participation in government through election or otherwise; protections during criminal trials; and freedom of thought, religion, and assembly. In addition, the Universal Declaration sets forth several economic- and social-oriented rights, including the rights to work; social security; rest and leisure; a "standard of living adequate for the health and well-being of himself and of his family"; education; and participation in cultural life. See generally Universal Declaration, supra note 44 . While the Universal Declaration is not a treaty, nor is it legally binding on states, many of its provisions have become embedded in customary and/or conventional international law, and thus, have arguably become binding on states.

51. See International Covenant, supra note 44.

52. See American Convention, supra note 44.

53. In choosing to focus on the International Covenant and the American Convention, this Author by no means implies that the rights contained in other human rights treaties (most notably those delineated supra note 44) are any less significant. However, the political and civil rights contained in the International Covenant and the American Convention contain the building blocks of international human rights law and hence are often called the "first 
The survey revealed that South American constitutions fall into one of two broad groups. ${ }^{54}$ The first group includes constitutions that incorporate the "spirit" of human rights treaties. ${ }^{55}$ In general, these constitutions are skeletal reflections of international human rights treaties, incorporating many core rights-core ideas-but lacking the flesh to make these rights as robust as their treaty-based counterparts. The second group, on the other hand, incorporates the texture and nuances of international treaty-based rights.

Constitutions in the first group frequently are "missing" several rights found in the international treaties, leaving conspicuous gaps in the constitutional treatment of human rights. None of the constitutions in this group contain the following rights: the right to self-determination; ${ }^{56}$ an explicit gender equality provision; ${ }^{57}$ a provision for the minimum due process rights for aliens facing expulsion; ${ }^{58}$ a prohibition on traffic in women; ${ }^{59}$ or the right to recognition as a person before the law. ${ }^{60}$ Most constitutions in this group lack a provision promising prisoners "humane" treatment, including segregation of convicted criminals from those criminal defendants awaiting trial and segregation of juveniles from adults; ${ }^{61}$ granting ethnic or religious minorities the right to enjoy their culture and group identity; ${ }^{62}$ prohibiting war propaganda and advocacy of racial, national or religious hate; ${ }^{63}$ and prohibiting imprisonment for contractual debt. ${ }^{64} \mathrm{~A}$ few of the constitutions have some dramatic omissions. The Venezuelan and Uruguayan

generation" of human rights. See generally Louis B. Sohn, The New International Law: Protection of the Rights of the Individual Rather than States, 32 AM. U. L. REV. 1, 17-32 (1982).

54. For a comprehensive comparison of South American constitutions, please refer to Table 3: Constitutional Treatment of Human Rights in South America, which is appended to this Article.

55. See Const. Bol.(1967, amended 1995); CONST. CHILE(1980, amended 1989); ConsT. PERU (1993); CONST. URU. (1967, reinstated 1985); CONST. VENEZ. (1961, amended 1983).

56. See International Covenant, supra note 44 , art. 1.

57. See id. art. 3.

58. See id. art. 13; American Convention, supra note 44, art. 22(6).

59. See American Convention, supra note 44, art. 6.

60. See International Covenant, supra note 44, art. 16; American Convention, supra note 44 , art. 3.

61. See International Covenant, supra note 44, art. 10; American Convention, supra note 44, art. 5. Chile's Constitution provides for segregation of convicted and arrested prisoners but does not provide for segregation of juveniles from adults. See CONST. CHILE art. 19(7)(d). Thus, this constitutional provision is narrower than the international counterparts.

62. See International Covenant, supra note 44, art. 27. But see CONST. PERU art. 2(19).

63. See International Covenant, supra note 44, art. 20; American Convention, supra note 44, art. 13(5). But see CONST. VENEZ. art. 66.

64. See International Covenant, supra note 44, art. 11; American Convention, supra note 44, art. 7(7). But see CONST. PERU art. 2(24)(c); CONST. URU. art. 52. 
Constitutions contain no clause prohibiting slavery and slave trade. ${ }^{65}$ Chile's Constitution contains no prohibition on torture or other cruel, inhumane or degrading treatment. ${ }^{66}$ Uruguay's Constitution does not proscribe the use of ex post facto laws ${ }^{67}$ and does not grant citizens freedom of thought, conscience or religion. ${ }^{68}$ While the American Convention also excludes some of these rights, ${ }^{69}$ the aforementioned constitutions are striking in their omission of several rights in addition to those that the American Convention chose not to codify.

Those rights that the constitutions include tend to be skeletal replicas of the rather developed rights found in the International Covenant and the American Convention. ${ }^{70}$ Other rights are significantly less expansive in scope. For example, criminal defense rights are

65. See International Covenant, supra note 44, art. 8; American Convention, supra note 44 , art. 6.

66. See International Covenant, supra note 44, art. 7; American Convention, supra note 44 , art. 5(2).

67. See International Covenant, supra note 44, art. 15; American Convention, supra note 44 , art. 9.

68. See International Covenant, supra note 44, art. 18; American Convention, supra note 44 , art. 12.

69. The American Convention does not include the following: the right to selfdetermination [see International Covenant, supra note 44, art. 1]; an explicit gender equality provision [although the American Convention has a generic equal protection clause, (see American Convention, supra note 44, art. 24), it does not explicitly provide for gender equality (see International Covenant, supra note 44, art. 3)]; and the right of ethnic and religious minorities to enjoy their culture and group identity [see International Covenant, supra note 44, art. 27]. See also Table 2 in the Appendix for a comparison of the International Covenant and the American Convention.

70. For example, the International Covenant states in Article 21: "The right of peaceful assembly shall be recognized. No restrictions may be placed on the exercise of this right other than those imposed in conformity with the law and which are necessary in a democratic society in the interests of national security or public safety, public order, the protection of public health or morals or the protection of the rights and freedoms of others." International Covenant, supra note 44, art. 21. Likewise, Article 22 states: " 1 . Everyone shall have the right to freedom of association with others, including the right to form and join trade unions for the protection of interests. 2. No restrictions may be placed on the exercise of this right other than those which are prescribed by law and which are necessary in a democratic society in the interests of national security or public safety, public order, the protection of public health or morals or the protection of the rights and freedoms of others. This article shall not prevent the imposition of lawful restrictions on members of the armed forces and of the police in their exercise of this right." International Covenant, supra note 44, art. 22 . The American Convention provides for similar rights. See American Convention, supra note 44 , arts. 15,16 . In contrast, Bolivia merely grants each person the right "[to] assemble and to associate for lawful purpose." CONST. BOL. art. 7(c). Venezuela merely grants each person the "right of association for lawful ends" and the "right to meet with others, publicly or privately without previous permission, for lawful ends and without arms." CONST. VENEZ. arts. 70, 71. In addition, the international instruments' family rights provisions (see International Covenant, supra note 44, art. 23; American Convention, supra note 44 , art. 17), which not only highlight the preeminence of the family but which further grant the right to consensual marriage and equality of spouses during marriage and upon dissolution, give way to simplistic proclamations that "[t]he family is the basis of our society," (CONST.URU. art. 40), and that "[t] 
generally sparse, granting many fewer protections than those granted in the International Covenant and American Convention. ${ }^{71}$ The freedom of conscience and religion clauses in some constitutions are rather narrow. ${ }^{72}$ As opposed to the approach in the international treaties, many constitutions" "right to life" provisions do not evince discomfort with

71. See International Covenant, supra note 44, art 14; American Convention, supra note 44, art. 8. See also Table 2 in the Appendix for a delineation of the rights of criminal defendants in the International Covenant and the American Convention, and Table 3 in the Appendix for a comparison of South American constitutions vis-à-vis these rights.

The Constitution of Bolivia merely includes protection from self-incrimination, a presumption of innocence, a general right to a defense, and the right to be assisted by a defense attorney. See CONST. Bol arts. 14, 16.

The Constitution of Pers only provides for a few criminal defense protections, namely the presumption of innocence and a prohibition on the admissibility of coerced statements (which is not explicitly set forth in the International Covenant or American Convention), and lacks most of the other rights found in the International Covenant and American Convention. See CONST. PERU arts. 2(24)(e), 2(24)(h).

The Constitution of Venezuela provides for some criminal defense rights, but it does not provide for a right to defense counsel, a right to an interpreter, a right to prepare a defense, or a right to appeal. See CONST. VENEZ. art. 60.

The Constitution of Chile, in its delineation of criminal defense rights, includes provisions regarding the following: adequate time for the preparation of defenses, a prohibition on double jeopardy, the right to an interpreter, and the right to be informed of the charges pending against the criminal defendant. See CONST. CHILE arts. 19(3), 7.

Uruguay's criminal rights provisions lack the right to be informed of charges; the right to a defense lawyer; the right to an interpreter; a prohibition on placing a criminal defendant in double jeopardy; and the right to an appeal. See CONST. URU arts. 12, 20-22.

72. For example, the Constitution of Bolivia contains a rather narrow freedom of thought and freedom of religion clause. The International Covenant provides that "Everyone shall have the right to freedom of thought, conscience and religion. This right shall include freedom to have or to adopt a religion or belief of his choice, and freedom, either individually or in community with others and in public or private, to manifest his religion or believe in worship, observance, practice and teaching." International Covenant, supra note 44, art. 18(1). The American Convention provides, "Everyone has the right to freedom of conscience and of religion. This right includes freedom to maintain or to change one's religion or beliefs, and freedom to profess or disseminate one's religion or beliefs either individually or together with others, in public or in private." American Convention, supra note 44, art. 12(1). The Constitution of Boliviastates, "The State recognizes and upholds the Roman Catholic Apostolic Religion. It guarantees the public exercise of any other worship." CONST. BOL. art. 3. Bolivia merely guarantees the public, not the private, exercise of worship, and does not explicitly protect freedom of thought or conscience; nor does Bolivia's Constitution fully develop the right in terms of choices and dissemination of ideas. 
the death penalty. ${ }^{73}$ Constitutional clauses regarding torture appear thin when juxtaposed with international analogs. ${ }^{74}$

Some constitutional provisions in this group ostensibly mimic international treaties but carve elastic exceptions that envelop the substantive right. Some constitutions exclude entire groups of people from constitutional protections. ${ }^{75}$ Frequently, "state of emergency" provisions, which allow the executive (usually with some type of nodding acquiescence from the legislature) to suspend certain rights in the face of an extreme crisis, are artfully drafted to create gaping loopholes that detract from the potency of many rights. Sometimes the triggering event-the emergency-is defined in such broad, catch-all terms that the executive could "legitimately" invoke the "state of emergency" clause in a wide range of situations. ${ }^{76}$ The International

73. The International Covenant and the American Convention strongly disfavor the death penalty's use in their "right to life" provisions. See International Covenant, supra note 44 , art. 6; American Convention, supra note 44, art. 4. These instruments support the abolition of the death penalty [see International Covenant, supra note 44, art. 6(6); American Convention, supra note 44, art. 4(3)], and, at a minimum, proscribe countries from imposing the death penalty for anything but the most serious crimes [see International Covenant, supra note 44, art. 6(2); American Convention, supra note 44, art. 4(2)], and from extending the death penalty "to crimes to which it does not presently apply" [American Convention, supra note 44, art. 4(2)]. Peru's "right to life" provision does not bar or curtail the death penalty's use but merely states that "Every person has the right to life, to his identity, to his moral, spiritual, and physical integrity." CONST. PERU art. 2(1). Chile's "right to life" provision does not disapprove of or strongly disfavor the death penalty, stating, "The Constitution guarantees to all persons the right to life and to the physical and psychological integrity of the individual .... The death penalty may only be instituted for a crime considered in law approved by a qualified quorum." CONST. CHLE art. 19(1).

74. The International Covenant and the American Convention respectively state that no one "shall be subjected to torture or to cruel, inhumane, or degrading punishment or treatment." International Covenant, supra note 44, art. 7; American Convention, supra note 44, art. 5(2). The Constitution of Venezuela states that "No one may be ... subjected to torture or to other proceedings which cause physical or moral suffering." CONST. VENEZ. art. 60(3). This phrasing is conspicuously distinct and appears to be narrower than the International Covenant or the American Convention. The Constitution of Uruguay prohibits brutal treatment in prisons but does not prohibit such treatment outside of prisons, nor is it clear that brutal treatment encompasses all instances when the proscription on "torture or other cruel, inhuman or degrading treatment" may apply. CONST. URU. art. 26.

75. For instance, Peru's constitutional provision regarding "personal freedom and security" contains many of the same protections found in Article 9 of the International Covenant and in Article 7 of the American Convention-no arbitrary arrest, right to be informed about the reasons for the arrest, prompt recourse to judicial scrutiny of legality of custody-but suspends these very protections when suspected drug traffickers, terrorists, or spies are under scrutiny. See CONST. PERU art. 2(24)(f).

76. Certain rights may only be suspended under the International Covenant "[i]n time of public emergency which threatens the life of the nation." International Covenant, supra note 44, art. 4(1). The American Convention's "state of emergency" provisions may only be invoked "[i]n time of war, public danger, or other emergency that threatens the independence or security of a State Party." American Convention, supra note 44, art. 27(1).

Peru's Constitution sanctions usage of the "state of emergency" clause "in case of a disturbance of the peace or of the internal order, catastrophe, or grave circumstances affecting 
Covenant and American Convention do not allow derogation of certain rights, even when a "state of emergency" is in effect. ${ }^{77}$ Most constitutions, like the International Covenant and the American Convention, limit the number of rights/prohibitions that the executive and/or legislature may curtail. This list, however, is frequently shorter than the International Covenant and the American Convention, meaning that the number of suspendable rights is somewhat greater. ${ }^{78}$ In providing for basic core rights, these constitutions are true to the "spirit" of the international human rights treaties but do not mirror their nuances, depth, or texture.

The second group of constitutions ${ }^{79}$ integrates not merely the spirit, but also the letter, of international human rights treaties. These constitutions emulate, or even surpass, international treaties in scope and breadth. In this group, international treaties conspicuously infiltrate national constitutions, serving as models for the content and scope of constitutional rights.

In general, the constitutions in the second group contain most of the rights enumerated in the International Covenant and the American Convention..$^{80}$ Constitutional provisions tend to mirror international

the life of the nation." CONST. PERU art. 137(1). Venezuela's "state of emergency" clause covers internal or external conflicts, "disorder that may disturb the peace," or "grave circumstances that affect economic or social life." CONST. VENEZ. arts. 240-41. Under Chile's state of emergency provision, enumerated rights may be suspended during "foreign or internal war, internal disturbances, emergency, and public calamity." CONST. CHILE art. 39.

77. The International Covenant and the American Convention do not permit suspension of the following rights/prohibitions: right to life [see International Covenant, supra note 44, art. 6; American Convention, supra note 44, art. 4]; freedom of thought [see International Covenant, supra note 44, art. 18; American Convention, supra note 44, art. 13]; torture [see International Covenant, supra note 44, art. 7; American Convention, supra note 44, art. 5(2)], slavery [see International Covenant, supra note 44, art. 8; American Convention, supra note 44, art. 6], imprisonment for contractual liability [see International Covenant, supra note 44, art. 11; American Convention, supra note 44, art. 7(7)]; expost facto laws [see International Covenant, supra note 44, art. 15; American Convention, supra note 44, art. 9]; and recognition as a person before the law [see International Convention, supra note 44, art. 16]. In addition, the American Convention does not allow derogation from the following rights: right to judicial personality [See American Convention, supra note 44, art. 3]; right to family [see id. art. 17]; children's rights [see id. arts. 17(5), 18, 19, 20]; and the right to participate in government [see id. art. 23].

78. For example, Venezuela apparently permits the suspension of most rights. See CoNsT. VENEZ. arts. $240-42,244$. Similarly, Unuguay allows the derogation of all rights related to individual security in order to apprehend "guilty parties," presumably including the right to life, the prohibition on torture, and the prohibition on punishment for contractual liability. See CONST. URU. art. 31.

79. See CONST. BRAZ. (1988); CONST. COlOM. (1991); CONST.ECuAdOR(1979, amended 1992); CONST. PARA. (1992).

80. The Constitution of Brazil is the most stunning, at least touching upon all of the rights except for one: the right to recognition as a person. The Constitution of Colombia is only missing three rights: the right to self-determination (which is not included in the American Convention); an explicit provision regarding segregation of different types of prisoners; and a prohibition on war propaganda and advocacy of racial, national or religious hate. The 
rights $;{ }^{81}$ other provisions, most notably constitutional protection of criminal defendants, ${ }^{82}$ are significantly more robust than those developed in the international instruments. ${ }^{83}$ Some constitutions expand the scope of various rights. ${ }^{84}$ Other constitutional rights are more potent

Constitution of Ecuador lacks four rights: an explicit provision regarding segregation of different types of prisoners; a provision regarding due process rights for aliens facing expulsion; the right to recognition as a person; and a prohibition on war propaganda and advocacy of racial, national or religious hate. The Constitution of Paraguay is missing the right to selfdetermination, the right to recognition as a person, prohibition of war propaganda, and basic children's rights.

81. For example, the International Covenant and the American Convention mandate State Parties to segregate certain classes of prisoners from other classes: juveniles must be segregated from adults, and those accused should be segregated from those convicted. See International Covenant, supra note 44, art. 10; American Convention, supra note 44, arts. 5(3), 5(4). Most of the constitutions in the first group omit this right all together. See supra note 61 and accompanying text. Paraguay's Constitution not only includes this right but echoes the international instruments - also demanding that juveniles and adults, as well as the accused and the convicted, should be separated. See ConST. PARA. art. 21.

The American Convention provides generically that no one shall be imprisoned for failure to pay a debt, yet further specifies that this provision does not apply for orders issued for "nonfulfillment of duties of support." See American Convention, supra note 44, art. 7(7). Brazil similarly draws an exception to the general rule for "defaults on an alimony obligation." CONST. BRAZ. art. 5(LXVII).

82. See supra note 71 and Table 2 in the Appendix for the international instruments' treatment of criminal defense rights. In Paraguay's Constitution, the "personal liberty and security" provision, covering arrest procedures, provides for all the rights granted in international treaties but also explicitly grants criminal defendants the right to have family members or other designated individuals informed of the arrest; the right to engage an interpreter as soon as the detention begins; and the right to remain silent. See CONST. PARA. arts. 12(2), 12(4), 12(1). Paraguay's criminal defense rights, covering the trial itself, are also significantly enhanced, including the right to have copies of all relevant documents; the right "to offer, produce, check, and reject evidence"; and the right "to have the court dismiss any evidence produced or proceedings carried out in violations of legal provisions." CONST. PARA. arts. 17(7), 17(8), 17(9). Brazil's Constitution also expands criminal defense rights: the arrest and place of detention shall be communicated to the detainee's family; the accused has the right to remain silent; the right to a jury; and illegal evidence will not be used in trial. See Const. BRAZ. arts. 5(LXII), 5(LXIII), 5(XXXVIII), 5(LVI). Colombia's Constitution explicitly forbids use of illegally obtained evidence. See CONST. COLOM. art. 29.

83. The International Covenant and the American Convention set forth a basic right to freedom of association, including the right to join trade unions; but carve exceptions to this right in the name of "national security or public safety, public order, the protection of public health or morals or the protection of the rights and freedom of others"; and state that governments may lawfully restrict members of the armed forces and police in their exercise of this right. International Covenant, supra note 44, art. 22; American Convention, supra note 44, art. 16. The Brazilian Constitution provides for the following: "freedom of association for lawful purposes is complete, but any paramilitary association is prohibited"; "creation of associations and, as set forth in law, of cooperatives, requires no authorization, prohibiting state interference in their operations"; "associations may be compulsorily dissolved or have their activities suspended only by court decision; in the former case a final and unappealable decision is required"; and "no one can be compelled to join an association or to remain in one." CONST. BRAZ. arts. 5(XVII), 5(XVIII), 5(XIX), 5(XX). See also ConsT. ColOM. arts. 38-39.

84. The international instruments provide for humane treatment of prisoners by mandating segregation of different groups of prisoners. See International Covenant, supra note 44, art. 10; American Convention, supra note 44, arts. 5(3), 5(4). The Brazilian Constitution enhances this right by providing for segregation with regard to age, sex, and criminal offense and further 
because they are affirmative, creating state obligations. ${ }^{85}$ Some constitutional rights are stronger because they eliminate encroaching exceptions. $^{86}$

When substantive treatment of human rights norms is a comparative axis, constitutions split into two groups. However, these groups share two traits. First, international human rights treaties clearly provided a foundation-some type of model-for constitutional

providing that "female prisoners shall be assured conditions that allow them to remain with their children during the period of breast-feeding." CONST. BRAZ. arts. 5(XLVIII), 5(L).

Colombia's equal protection clause extends protection beyond the delineated categories to "those individuals who on account of their economic, physical, or mental condition are in obviously vulnerable circumstances." CONST. COLOM. art. 13.

85. For example, Paraguay's Constitution not only assures equality to "all residents as far as dignity and rights are concerned" (CONST. PARA. art. 46) and makes explicit equality assurances to men and women (see id. art. 48), but also creates potent, affirmative state duties: "The State will remove all obstacles and prevent those factors that support or promote discrimination," (id. art. 46); "The State will create conditions conducive to, and will create adequate mechanisms for, making this equality true and effective by removing those obstacles that could prevent or curtail this equality as well as by promoting women's participation in every sector of national life." (id. art. 48). While the International Covenant and the American Convention also impose obligations upon States Parties to assure that all persons have "free and full exercise" of rights in a non-discriminatory manner, the obligations imposed by Paraguay's Constitution are much more robust, requiring not only removal of obstacles impeding equality but also prevention of those factors that support or promote discrimination. See International Covenant, supra note 44, art. 2; American Convention, supra note 44, art. 1.

86. See supra notes 78-81 and accompanying text. The Constitution of Colombia does not allow suspension of any "human rights" or "fundamental freedoms" and provides that " $[\mathrm{i}] \mathrm{n}$ all cases, the rules of international humanitarian law will be observed." CONST.COLOM. art. 214.

The international instruments' freedom of speech, religion, and association/assembly rights contain a strong exception: they may be restricted in the name of national security, public safety, public order, the protection of public health or morals, and in respect of the rights or reputations of others. See International Covenant, supra note 44, art. 18 (religion and conscience, excluding national security), art. 19 (expression and opinions), art. 21 (assembly); art. 22 (association). See also American Convention, supra note 44, art. 12 (conscience and religion, excluding reputation and national security), art. 13 (thought and expression), arts. 15, 16 (assembly and association, excluding reputation). However, the Constitution of Paraguay does not carve such exceptions for some of these rights, and for others it narrows the scope of the exception, thereby enhancing the breadth of the right. Article 26, concerning "freedom of expression and the press," does not carve any exceptions. ConST. PARA. art. 26. The right to assembly, Article 32, only carves exceptions in "areas of public traffic control, at certain hours, to preserve public order and the rights of others." Id. art. 32. Similarly, the Constitution of Brazil merely excepts meetings which "interfere with another meeting previously called for the same place" from its general freedom of assembly clause. "[P]rior notice to the proper authority" is an additional prerequisite to freedom of assembly. CONST. BRAZ. art. 5(XVI). Similarly, Brazil's freedom of association provisions do not carve out the same type of expansive exceptions, merely prohibiting "paramilitary association." Id. arts. 5(XVII-XX). The Colombian Constitution does not load its freedom of conscience, religion, and association provisions with restrictive exceptions. See Const. COLOM. arts. 18, 19, 38-39. The Constitution of Ecuador does not place restrictions on the freedom of assembly or the freedom of association and limits exceptions for the freedom of opinion and expression provision by providing "[a]ny person who was affected by inaccurate statements or whose honor injured by the press or other means of social communication will have the right to have the corresponding rectification made by them free of charge." CONST. ECUADOR arts. 19(13), 31(h), 19(4). 
development of individual rights. ${ }^{87}$ Second, no constitution, not even those in the second group, contains all of the rights delineated in the international treaties. Those constitutions that incorporated most rights did not consistently emulate the scope and breadth of such rights, opting to curtail some rights while enhancing others. One can only speculate regarding the constitutional drafters' frame of mind at the inception of these constitutions. It is reasonable, however, to imagine a deliberative process that resulted in the inclusion of some rights, at the expense of others, as well as an attenuation of the scope of certain rights.

\section{Constitutional Status of Human Rights Norms}

Many modern constitutions address the status of international human rights norms or, more generally, international law. ${ }^{88}$ As in the previous section, this Article will focus on South American constitutions, and suggests the following broad groupings: 1) constitutions which place international treaties on a par with domestic law; 2) constitutions that deem international treaties superior to domestic law but inferior to the constitution; and 3) constitutions that do not explicitly (or implicitly) address the status of international law.

87. See, e.g., A.E. Dick Howard, The Indeterminacy of Constitutions, 31 WAKE FOREST L. REV. 383, 387 (1996).

88. For a comprehensive survey of the constitutional treatment of international treaties, see Hurst Hannum, The Status of the Universal Declaration of Human Rights in National and International Law, 25 GA. J. INT'L \& COMP. L. 287, 355 (1996) (Annex I: Constitutional Provisions Referring to the Status of International Law, Including References to the Universal Declaration of Human Rights).

While beyond the scope of this Article, the constitutional status of human rights treaties, principally the European Convention on Human Rights, has been a significant aspect of constitutional reform efforts in Central and Eastern Europe. See European Convention for the Protection of Human Rights and Fundamental Freedoms, opened for signature Nov. 4, 1950, Europ. T.S. No. 5, 213 U.N.T.S. 222 (entered into force Sept. 5, 1953). See also Howard, supra note 87, at 387-88; Eric Stein, International Law in Internal Law: Toward Internationalization of Central-Eastern European Constitutions?, 88 AM.J.INT'LL. 427 (1994); Wiktor Osiatynski, Rights in New Constitutions of East Central Europe, 26 COLUM. HuM. RTS. L. REv. 111, 161 (1994); Dalibor Jilek, Human Rights Treaties and the New Constitutions, 8 CONN. J. INT'L L. 407 (1993). 
The following table sets forth the relevant constitutional provisions.

Table 1: South American Constitutions and the Status of International Law

\begin{tabular}{|c|c|}
\hline Country & Constitutional Provisions \\
\hline $\begin{array}{l}\text { Bolivia } \\
\text { (1967; } \\
1995 \text { amend.) }\end{array}$ & $\begin{array}{l}\text { Art. 228: The Constitution of the State is the supreme law of the } \\
\text { national juridical system. The courts, judges, and authorities shall } \\
\text { apply it with preference over the laws, and the laws with preference } \\
\text { over any other resolutions. } \\
\text { Art. } 96(2) \text { : The powers and duties of the President of the Republic } \\
\text { are... to negotiate and conclude treaties with foreign nations; and to } \\
\text { exchange them when ratified by Congress. } \\
\text { Art. } 59 \text { (12): The following are the functions of the legislative power . } \\
\text {. to approve international treaties, concordats and conventions. }\end{array}$ \\
\hline $\begin{array}{l}\text { Brazil } \\
(1988)\end{array}$ & $\begin{array}{l}\text { Art. } 4 \text { : The international relations of the Federative Republic of } \\
\text { Brazil are governed by the following principles:... prevalence of } \\
\text { human rights. } \\
\text { Art. } 49 \text { (I): The National Congress shall have exclusive powers to } \\
\text { decide definitively on international treaties, accords or acts that } \\
\text { involve serious changes or commitments on the national patrimony. } \\
\text { Art. } 84 \text { (VIII): The President of Brazil has the exclusive power to... } \\
\text { enter into international treaties, conventions and acts, subject to the } \\
\text { approval of Congress. }\end{array}$ \\
\hline $\begin{array}{l}\text { Chile } \\
\text { (1980; } \\
1989 \text { amend.) }\end{array}$ & $\begin{array}{l}\text { Art. } 5: \text { It is the duty of state agencies to respect and promote the } \\
\text { rights guaranteed by this Constitution and by international treaties } \\
\text { ratified by Chile and in force. } \\
\text { Art. } 32(17): \text { [ The President has the power to sign and ratify treaties, } \\
\text { but they] must be submitted to the approval of Congress as } \\
\text { prescribed for in Article } 50 \text {, No. } 1 \text {. } \\
\text { Art. } 50(1) \text { : The exclusive powers of Congress are: to approve or } \\
\text { reject international treaties submitted by the President of the } \\
\text { Republic prior to ratification thereof. The approval of a treaty shall } \\
\text { be subject to the procedures prescribed by a law. The measures } \\
\text { which the President of the Republic adopts or the agreements } \\
\text { concluded by him or the fulfilment of a treaty in force shall not } \\
\text { require new approval by the Congress, except in cases which } \\
\text { constitute a matter of law. }\end{array}$ \\
\hline $\begin{array}{l}\text { Colombia } \\
\text { (1991) }\end{array}$ & $\begin{array}{l}\text { Art. 93: International treaties and agreements ratified by the } \\
\text { Congress that recognize human rights and that prohibit their } \\
\text { limitation in states of emergency have priority domestically. The } \\
\text { rights and duties mentioned in this Charter will be interpreted in } \\
\text { accordance with international treaties on human rights ratified by } \\
\text { Colombia. }\end{array}$ \\
\hline
\end{tabular}




\begin{tabular}{|c|c|}
\hline $\begin{array}{l}\text { Ecuador } \\
\text { (1979; } \\
1992 \text { amend.) }\end{array}$ & $\begin{array}{l}\text { Art. 2: The primary function of the State is to strengthen national } \\
\text { unity, ensure the effectiveness of fundamental human rights. } \\
\text { Art. 44: The State guarantees to all individuals, male and female, } \\
\text { who are subject to its jurisdiction, free and effective exercise and } \\
\text { enjoyment of the civil, political, economic, social and cultural rights } \\
\text { enunciated in declarations, pacts, agreements and other international } \\
\text { instruments in force. } \\
\text { Art. 137: The Constitution is the supreme law of the land .... } \\
\text { Secondary norms and others of lesser importance must maintain } \\
\text { conformity with constitutional precepts. Laws, decrees, ordinances, } \\
\text { provincial, and international treaties or agreements that oppose the } \\
\text { Constitution or modify its precepts in any way shall be void. }\end{array}$ \\
\hline $\begin{array}{l}\text { Paraguay } \\
\text { (1992) }\end{array}$ & $\begin{array}{l}\text { Art. 137: The Constitution is the supreme law of the Republic. The } \\
\text { Constitution, the international treaties, conventions, and agreements } \\
\text { that have been approved and ratified by Congress, the laws dictated } \\
\text { by Congress, and other related legal provisions of lesser rank make } \\
\text { up the national legal system. This listing reflects the descending } \\
\text { order of preeminence. } \\
\text { Article } 141 \text { : International treaties that were properly concluded and } \\
\text { approved by a law of Congress and the instruments of ratification } \\
\text { which have been exchanged or deposited are part of the domestic } \\
\text { legal system in keeping with the order of preeminence established } \\
\text { under Article } 137 \text {. } \\
\text { Article 142: International treaties concerning human rights cannot be } \\
\text { renounced, but must follow the procedure established herein for the } \\
\text { amendment of this Constitution. } \\
\text { Article 143: In its international relations, the Republic of Paraguay } \\
\text { accepts international law and endorses the following principles:... } \\
\text { 5) International human rights. }\end{array}$ \\
\hline $\begin{array}{l}\text { Peru } \\
\text { (1993) }\end{array}$ & $\begin{array}{l}\text { Art. 55: Treaties signed by the State and in force are part of national } \\
\text { law. } \\
\text { Art. } 56 \text { : Treaties must be approved by the Congress before their } \\
\text { ratification by the President of the Republic if they involve the } \\
\text { following matters: } 1 \text { ) human rights; } 2 \text { ) sovereignty, dominion, or } \\
\text { integrity of the State.... } \\
\text { Art. } 57 \text { : The President of the Republic may accept or ratify treaties } \\
\text { without need for the prior approval of the Congress in matters not } \\
\text { covered in the previous article. In all these cases, he must render an } \\
\text { accounting to the Congress. When the treaty affects constitutional } \\
\text { provisions, it must be approved by the same procedure that applies to } \\
\text { amending the Constitution before being ratified by the President of } \\
\text { the Republic. The denunciation of treaties falls under the authority } \\
\text { of the President of the Republic who is responsible for rendering } \\
\text { account to the Congress. In the case of treaties subject to the } \\
\text { approval of the Congress, their denunciation requires its prior } \\
\text { approval. }\end{array}$ \\
\hline
\end{tabular}




\begin{tabular}{|l|l|}
\hline $\begin{array}{l}\text { Uruguay } \\
\text { reinstated 1995) }\end{array}$ & $\begin{array}{l}\text { Art. 85(7): The General Assembly is competent ... to declare war } \\
\text { and to approve or disapprove, by an absolute majority of the full } \\
\text { membership of both chambers, the treaties of peace, alliance, } \\
\text { commerce and conventions or contracts of any nature which the } \\
\text { Executive Power may make with foreign powers. } \\
\text { Art. 85(20): The Executive shall ... conclude and sign treaties, the } \\
\text { approval of the Legislative Power being necessary to their } \\
\text { ratification. }\end{array}$ \\
\hline $\begin{array}{l}\text { Venezuela } \\
(1961)\end{array}$ & $\begin{array}{l}\text { Art. 128: International treaties or conventions conducted by the } \\
\text { National Executive must be approved bya special law in order to be } \\
\text { valid, unless they concern the execution or completion of pre- } \\
\text { existing obligations of the Republic, the application of principles } \\
\text { expressed by it, the execution of ordinary acts in international } \\
\text { relations, or the exercise of powers which the law expressly bestows } \\
\text { on the National Executive. }\end{array}$ \\
\hline
\end{tabular}

The constitutions which place international law on a par with domestic law expose international norms to subsequent statutory invalidation. ${ }^{89}$ International treaty norms thus become vulnerable and manipulable, depending on the sentiments and mood of transient legislatures. The Peruvian Constitution clearly states that treaties are a part of "national law." The Venezuelan Constitution requires the legislature to pass laws validating all international treaties or conventions, relegating these international norms to the status of a domestic law. ${ }^{91}$ Other constitutions do not explicitly address the status of international law, but divide power over international treaties among the executive, who concludes treaties, and the legislative branch, which ratifies treaties. Domestic constitutional law interpreting these provisions frequently relegates international treaties to the status of a domestic statute. ${ }^{92}$

89. In United States jurisprudence, this is known as the "last-in-time" rule. See RESTATEMENT, supra note 35, \& 115(1), (2).

90. CONST. PERU art. 55. See also Table 1 supra.

91. See CONST. VENEZ. art. 128; Table 1 supra. Venezuela has determined, via its Constitution, that, for the most part, treaties will be non-self-executing, requiring domestic facilitating legislation prior to having legal effect. See RESTATEMENT, supra note 35, §\$ 111(3), 111(4). Most commentators believe that non-self-executing treaties, once executed, are tantamount to domestic statutes. See id. §111, cmts. (h), (i), reporter's notes 5, 6. See also Héctor Gros Espiell, Los Tratados sobre Derechos Humanos y el Derecho Interno in TEMAS DE DERECHO INTERNACIONAL: EN HOMENAJE A FRIDA M. PFIERTER DE ARMAS BAREA 61, 63 (R.E. Vineusa ed., 1989); MÓNICA PINTO, TEMAS DE DERECHOS HUMANOS 66 (1997) (stating that Venezuela's Constitution places international norms on a par with domestic law).

92. See Const. URU. arts. 85(7), 85(20). See also Table 1 supra; Héctor Gros Espiell, La Constitución y los Tratados Internacionales (Ministerio de Relaciones Exteriores, Montevideo, 1997) (discussing Uruguayan constitutional jurisprudence interpreting these provisions and concluding that international law and domestic law share the same legal status); PINTO, supra note 91, at 66 (stating that Uruguay's Constitution places international norms on a par with domestic law). See also CONST. BOL. arts. 59(12); 96(2); 228; PINTO, supra note 91, 
On the other hand, some constitutions explicitly elevate international norms, or a specific group of international norms. Paraguay's Constitution ranks sources of law, with international treaties and conventions falling below its Constitution but above "laws dictated by Congress." ${ }^{93}$ Colombia's Constitution elevates international treaties that "recognize human rights and that prohibit their limitation in states of emergency." "94 Ecuador's Constitution is not explicit in its treatment of international human rights norms; it sanctifies "fundamental human rights" the civil, political, economic, social and cultural rights enunciated in declarations, pacts, agreements and other international instruments in force," status of a "secondary" or non-constitutional norm. ${ }^{97}$ Juxtaposing these constitutional provisions, one can logically conclude that international treaty norms float somewhere between the Constitution and domestic law in Ecuador's domestic legal hierarchy.

Other constitutions leave the status of international norms ambiguous. Chile's Constitution, for example, mimics the constitutional division of power among the executive and the legislative branches found in the Uruguayan and Bolivian Constitutions, ${ }^{98}$ suggesting that international norms would be on a par with domestic norms. Yet, a relatively recent amendment to Chile's Constitution charges state agencies with the duty "to respect and promote the rights guaranteed" in international treaties, ${ }^{99}$ suggesting that such norms are cloaked with special domestic standing. Thus, Chile's Constitution is rather ambiguous regarding the precise status of international norms. ${ }^{100}$

The legal status of international treaties and conventions provides an additional axis for comparison of South American constitutions. Whether constitutions place international norms on a par with domestic law, above domestic law, or leave the issue unresolved, none of these

at 66 (arguing that Bolivia's Constitution places international norms on a par with domestic law).

93. CONST. PARA. art. 137. See also Table 1 supra; PINTO, supra note 91, at 64-65.

94. CONST. COLOM. art. 93. See also Table 1 supra; PINTO, supra note 91, at 69.

95. CONST. ECUADOR art. 2. See also Table 1 supra.

96. CONST. ECUADOR art. 44.

97. See id. art. 137.

98. See Table 1 supra.

99. CONST. CHILE art. 5. See also Table 1 supra.

100. See PINTO, supra note 91, at 69-70 (arguing that Chile's Constitution is ambiguous with regard to the status of international human rights norms).

Brazil's Constitution is similarly ambiguous. On one hand, the Brazilian Constitution lauds its commitment to human rights in its opening articles. See CONST. BRAZ. art. 4 (1988). On the other hand, it mirrors those constitutions which mechanically divide power among the executive and legislative branches. See id. arts. 49(I), 84(VIII); Table 1 supra; Espiell, supra note 91 , at 63 . 
constitutions explicitly or implicitly place international law on par with the constitution itself. ${ }^{101}$

\section{Argentina's Constitution In Context: Pre-1994}

The previous section develops two axes upon which constitutions may be compared vis-à-vis international human rights. In terms of substance, some constitutions incorporate the skeletal spirit of international human rights treaties, while others incorporate their nuances and breadth. In terms of status, some constitutions place international treaties on a par with domestic law, while others anoint international norms with a status superior to domestic law. Argentina's 1994 constitutional reforms dramatically changed where its Constitution falls on these two axes.

\section{Constitutional Status of Human Rights}

Prior to 1994, Argentina's Constitution did not explicitly address the status of international treaties. Similar to the Uruguayan, Brazilian and Bolivian Constitutions, ${ }^{102}$ Argentina's Constitution divided power over international treaties among the three branches. ${ }^{103}$ The Constitution also stated in Article 31 that the Constitution, the laws that are passed by Congress pursuant to the Constitution, and treaties with foreign powers are the supreme law of the land; and that provincial authorities are obliged to conform to this law ${ }^{104}$-suggesting some type of parity between the Constitution and international treaties. On the other hand, the Constitution provided in Article 27 that " $[t]$ he federal government will be charged with relations with foreign powers, through

101. See PINTO, supra note 91, at 66; Espiell, supra note 91, at 64.

While none of the South American constitutions place international norms on par with constitutional norms, some European constitutions arguably elevate international norms to a constitutional status. Id. at 64-65. See also supra notes 93-97 and accompanying text; CoNST. CZECH REP. art. 10 (Dec. 21, 1992)("Ratified and promulgated international treaties on human rights and fundamental freedoms to which the Czech Republic is a party are directly binding and take precedence over the law"); CONST. SLOVK. art. 1 (Sept. 8, 1992) ("International treaties on human rights and basic liberties that were ratified by the Slovakia and promulgated in a manner determined by law take precedence over its own laws, providing that they secure a greater extent of constitutional rights and liberties"); CONST. HUNG. art. 7 (Dec. 31, 1990) ("The legal system of the Republic of Hungary accepts the universally recognized rules and regulations of international law, and harmonizes the internal laws and statutes of the country with the obligations assumed under international law."). Constitutional jurisprudence in some Central American countries, namely Nicaragua, Panama, and Costa Rica, suggests that some international norms may have constitutional standing. See INSTITUTO INTERAMERICANO DE DERECHOS HUMANOS, GUÍA SOBRE APLICACIÓN DEL DERECHO INTERNACIONAL EN LA JURISDICCIÓN INTERNA 42 (1996).

102. See supra notes $92 \& 105$ and accompanying text.

103. See supra notes $26-28$ and accompanying text.

104. See CONST. ARG. (1853) art. 31. 
treaties that are in conformity with the public principles that are set forth in this Constitution," 105 implying that international norms stand inferior to the Constitution. While many commentators interpreted Article 31 through a federalist lens, focusing on what it stated about province/federal government relations rather than what it stated about the status of international treaties vis-à-vis the Constitution, ${ }^{106}$ the juxtaposition of these various provisions created some ambiguity regarding the precise status of international norms. ${ }^{107}$

Argentine constitutional jurisprudence resolved some of this ambiguity prior to the 1994 constitutional reform. The most significant case was Ekmekdjián v. Sofovich. ${ }^{108}$ In this case, the petitioner sought to respond to some religiously "inflammatory" statements that the respondent read on television. ${ }^{109}$ In support, the petitioner relied on the "right to reply" found in the American Convention. ${ }^{110}$ Yet, domestic law also governed the "right to reply." In ultimately relying on the American Convention, the Court decided that an international treaty, properly ratified pursuant to the Constitution, ${ }^{111}$ stands superior to

105. Id. art. 27.

106. See PINTO, supra note 91, at 65 (discussing Article 31 and comparing it to similar language in the U.S. Constitution, which sets forth the preeminence of federal law in the legal hierarchy); Espiell, supra note 91, at 62.

107. See Marisa A. Graham \& Juan P. Cafiero, Tratados sobre Derechos Humanos, in JERARQUÍA CONSTITUCIONALDE LOS TRATADOS INTERNACIONALES, supra note 38, at 27, 28-31.

Many of the members of the Constitutional Assembly discussed this ambiguity. See PRoyectos IngResados No. 3, CONVENCION NACIONAL CONSTITUYENTE [Record of Constitutional Assembly] [hereinafter REC. CONST. ASSEMBLY], June 14, 1994, 10:00 P.M., at 547 (statement of Horacio Rosatti) (discussing the ambiguity that Article 31 creates); REC. CONST. ASSEMBLY No. 19, June 17, 1994, 11:00 A.M., at 786 (statement of Guillermo E. Estevez Boero, Alfredo P. Bravo \& Norberto L. La Porta) (same); REC. CONST. AsSEMBLY No. 22, June 22, 1994, 1:00 P.M., at 888 (statement of Augusto J.M. Alasino) (same); REC. CoNST. ASSEMBLY No. 24, June 22, 1994, 5:00 P.M., at 1013 (statement of Alberto A. Natale, Pablo A. Cardinale \& Carlos A. Caballero Martín) (same); REC. CONST. ASSEMBLY No. 26, June 23, 1994, 1:30 P.M., at 1255 (statement of Juan C. Hitters) (discussing the conflict between Articles 27 and 31); REC. CONST. ASSEMBLY No. 35, June 24, 1994, 5:30 P.M., at 1975 (statement of Alberto E. Balestrini) (discussing the tension between Articles 27 and 31 and the disparate views of the status of international treaties and conventions vis-à-vis the Constitution).

108. "Ekmekdjiån," CSJN (1992), reprinted in JUAN ANTONIO TRAVIESO, JURISPRUDENCIA DE loS TRIBUNALES ARGENTINOS SOBRE DERECHOS HUMANOS Y GARANTIAS 11 (1996) (concerning right to reply and freedom of speech) (translations of the case are by the Author).

109. Id. at 11 .

110. See id. at 11. See also American Convention, supra note 44, art. 14(1) ("Anyone injured by inaccurate or offensive statements or ideas disseminated to the public in general by a legally regulated medium of communication has the right to reply or to make a correction using the same communications outlet, under such conditions as the law may establish.").

111. CONST. ARG. (1853) art. 86(14) (Executive concludes and signs treaties), art. 67(19) (Congress approves treaties). 
domestic law. ${ }^{112}$ Thus, as opposed to the practice in the United States, ${ }^{113}$ a subsequent domestic law could not trump an international treaty provision, and Argentine domestic law could not constrict the scope or efficacy of international treaty provisions. ${ }^{114}$ Furthermore, the Court concluded that an international treaty provision, properly ratified, is presumptively self-executing ${ }^{115}$ as long as it is capable of "immediate operation, without additional institutions." 116 Thus, Ekmekdjián placed international treaties on a supra-statutory level and, by holding that they were presumptively self-executing documents, transformed them into a potent source of law which the Court itself harnessed to decide the case.

However, two subsequent Supreme Court opinions limited the reach of Ekmekdjián. In Fibraca, the Court examined a potential conflict between a treaty with the Holy See and the Constitution. ${ }^{117}$ The Court refused to extend the holding of Ekmekdjian to the Constitution, stating that international treaties' supra-statutory status did not place them on a par with the Constitution..$^{18}$ The Court thereby underscored that the Constitution reigned supreme in the legal hierarchy. In Hagelin, ${ }^{119}$ the lower court relied on the American Convention in granting the plaintiff indemnification for his daughter's illegal detention and subsequent disappearance, rather than a domestic indemnification law designed primarily as a remedy in light of Argentina's economic problems in the late 1980 s. $^{120}$ While the Court reaffirmed the supremacy of international law over domestic law, it held that the former trumps the latter only in the face of a real legal conflict, such that the conflicting laws must be significantly, if not completely, congruent and the underlying purposes behind the laws must be similar. ${ }^{121}$ Thus, if a domestic law is designed to deal with a specific problem, as the indemnification law in question, and an international norm deals more generically with a similar issue, the international norm is not deemed to

112. See Graham \& Cafiero, supra note 107, at 28 (citing several lower court cases that support the legal conclusions in Ekmekdjián).

113. See supra note 89 and accompanying text (discussing the last-in-time rule in the United States).

114. See "Cafés la Virginia S.A.," CSJN [1995-I] J.A. 686 (holding that any administrative action in violation of international treaties violates the supremacy of those treaties over internal law).

115. See supra note 35 (discussing self-executing treaties).

116. "Ekmekdjián," CSJN (1992), at 16.

117. See "Fibraca Constructora, S.C.A.," CSJN 154 E.D. 164, 165 (1993).

118. See id. at 165.

119. "Hagelin, Ragnar," CSJN (1993), reprinted in TRAVIESO, supra note 108, at 37.

120. See id. at 37-38. See also American Convention, supra note 44, art. 5(1) ("Every person has the right to have his physical, mental, and moral integrity respected.").

121. See "Hagelin," CSJN (1993) at 39. 
be in conflict and may not trump the domestic norm. ${ }^{122}$ On the eve of the constitutional reform, Argentina's Constitution could be aligned with those constitutions that place international law somewhere between domestic law and constitutional norms.

\section{Substantive Treatment of Human Rights}

As far as substantive treatment of human rights, Argentina's pre1994 Constitution was similar to those constitutions which are mere skeletal reflections of international human rights norms. ${ }^{123}$ Admittedly, the core of Argentina's Constitution pre-dated the advent of international human rights; however, the last two constitutional amendments (1949 and 1957) ${ }^{124}$ followed the United Nation's embracing of the Universal Declaration of Human Rights ${ }^{125}$ and could have provided an ample and meaningful opportunity for substantive incorporation of human rights norms.

Argentina's pre-1994 Constitution ${ }^{126}$ was "missing" several rights, most notably an equal protection-type clause, ${ }^{127}$ a prohibition on imprisonment for debts ${ }^{128}$ the right to peaceful assembly, ${ }^{129}$ and family/children's rights. ${ }^{130}$ Of the fifteen rights that Argentina shared with the international instruments, twelve were rather minimal, mimicking only the spirit of international norms rather than their scope or depth. ${ }^{131}$ In addition, Argentina's pre-1994 "state of emergency" provisions are classically expansive, providing the executive relatively unconstrained power to suspend constitutional guarantees in the face of an "internal disorder." 132

122. See id.

123. See supra notes $56-81$ and accompanying text.

124. See ConST. ARG. (amended 1949 and 1979).

125. See Universal Declaration, supra note 44.

126. See also Table 2: Argentina's Constitutional Treatment of Human Rights: Past and Present, in the Appendix, which compares Argentina's pre-1994 and post-1994 Constitutions in terms of human rights.

127. See International Covenant, supra note 44, art. 3; American Convention, supra note 44 , art. 24.

128. See International Covenant, supra note 44, art. 11; American Convention, supra note 44 , art. 7(7).

129. See International Covenant, supra note 44, art. 21; American Convention, supra note 44 , art. 15.

130. See International Covenant, supra note 44, arts. 23-24; American Convention, supra note 44, arts. 17(5), 18-20.

131. Table 2 indicates that Argentina shares nineteen rights with the International Covenant and the American Convention. Table 2 also indicates with a "--" sign that eleven of these rights are significantly less robust than their treaty counterparts.

132. CONST. ARG. (1853) arts. 23-29. 


\section{Argentina's 1994 Constitution}

Argentina's 1994 constitutional reform altered the Constitution's standing in terms of status and substance. Article 75(22) endowed nine international human rights treaties with constitutional standing, ${ }^{133}$ and otherwise reaffirmed the Supreme Court's decisions ${ }^{134}$ by providing all other international treaties with supra-statutory standing. ${ }^{135}$ Thus, domestic law cannot trump an international norm, and certain international human rights norms, to be interpreted in harmony with the rest of the 1994 Constitution, ${ }^{136}$ stand on par with the Constitution itself.

In terms of substance, it is important first to examine Argentina's new Constitution independent of Article 75(22), as set forth in the final column of Table 2 in the Appendix. Without Article 75(22), Argentina's Constitution remains highly reminiscent of its predecessor and similar to those constitutions that reflect the spirit, rather than the scope, of human rights treaties. ${ }^{137}$ Significantly, in reforming the Constitution in 1994, Argentina left Chapter 1, "Declaration, Rights, Guarantees," almost untouched. ${ }^{138}$ Chapter 2, "New Rights and Guarantees," a fresh addition to the 1994 Constitution, presented Argentina with the opportunity to "update" many rights, adding nuances to make its constitutional rights as robust as those in the international documents. Chapter 2, however, only nominally improved Argentina's substantive inclusion of human rights as set forth in the American Convention and International Covenant. The Constitution now provides explicitly for "equality of opportunity and treatment and the full exercise of rights recognized in this Constitution",139 "real equality of opportunity between men and women in accessing elected and party

133. See supra note 44 and accompanying text.

134. See supra notes 108-22 and accompanying text (discussing recent Argentine Supreme Court decisions regarding status of international law).

135. See supra note 48 and accompanying text.

136. See supra note 46 and accompanying text. See infra note 242 and accompanying text.

137. See supra notes 55-78 and accompanying text.

138. Chapter 1 of the 1994 Constitution is identical to its 1853 predecessor. With the exception of some relatively minor changes in Article 22 (regarding the nature of representative government) and some mildly limiting language in the "state of emergency" provision ("Congress may not confer on the National Executive, nor the Provincial Legislatures or the Provincial Governors extraordinary powers, nor the whole of the public authority, nor grant them acts of submission or supremacy whereby the lives, honor or the property of Argentineans will be at the mercy of governments or any person whatsoever"), CONST. ARG. (1994) arts. 22, 29 (underlined language indicates 1994 amendments). See also Table 2 in the Appendix which shows that those rights which were "missing" from the pre-1994 Constitution are generally missing from the post-1994 Constitution.

139. CONST. ARG. (1994) art. 75(23). See also International Covenant, supra note 44, art. 2; American Convention, supra note 44 art. 1. 
office"; ${ }^{140}$ habeas corpus; ${ }^{141}$ ethnic and religious minority rights; ${ }^{142}$ and somewhat veiled allusions to children's rights. ${ }^{143}$ In addition, Chapter 2 begins with a reaffirmation of the Constitution and the democratic system. ${ }^{144}$ Otherwise, Chapter 2 differs from the type of fundamental rights included in the International Covenant and the American Convention, addressing instead political corruption, ${ }^{145}$ political parties, ${ }^{146}$ environmental rights, ${ }^{147}$ and consumer protection. ${ }^{148}$ While these aforementioned rights, if implemented, will significantly improve the human rights situation in Argentina, Argentina's Constitution still lacks explicit reference to many rights, most notably, the right to peaceful assembly ${ }^{149}$ and protection from imprisonment for debts. ${ }^{150}$

The Argentine Constitutional Assembly also failed to embrace the constitutional reform process as an opportunity to fortify those barebones rights which the 1853 Constitution listed. Protections for criminal defendants remain scant; ${ }^{151}$ with the exception of the added

140. CONST. ARG. (1994) art. 37 ("This Constitution guarantees full enjoyment of political rights, in accordance with the principle of popular sovereignty and with laws dictated pursuant thereto. Suffrage is universal, equal, secret, and mandatory. Real equality of opportunity between men and women in accessing elected and party office is guaranteed through positive actions in the regulation of political parties and in the electoral system."). See also International Covenant, supra note 44, arts. 3, 25; American Convention, supra note 44 arts. 23-24.

141. See CONST. ARG. (1994) art. 43 ("When the right which has been harmed, restricted, altered, or threatened related to physical liberty or to a case of illegal worsening in the form or conditions of detention, or in the forced disappearance of persons, the writ of habeas corpus may be imposed by the affected person or by someone else to benefit him; the judge is to resolve the issue immediately, even while there is a state of siege."). Article 43 also provides for an amparo, which is a "quick, expedient action to protect himself, as long as no other more appropriate judicial means exist, against any act or omission of public authorities or any individuals, who actually or imminently, harm, restrict, alter or threaten rights and guarantees recognized by this Constitution." Id. See International Covenant, supra note 44, art. 9; American Convention, supra note 44 art. 7(1-6).

142. See ConST. ARG. (1994) art. 75(17) ("Congress shall have the power... [t] recognize the ethnic and cultural pre-existence of indigenous Argentinean peoples."). See also International Covenant, supra note 44, art. 27.

143. See CoNST. ARG. art. 75(23) ("Congress shall have the power... [t]o legislate and promote means of positive action that guarantee . . . the rights of children [and] women.").

144. See id. art. 36 ("This Constitution remains in power even when its observance is interrupted by acts of force against the institutional order and the democratic system. These acts are irredeemably null ....").

145. See id. ("Congress shall pass a law concerning public ethics for the exercise of that function ....").

146. See id. art. 38.

147. See id. art. 41.

148. See id. art. 42.

149. See International Covenant, supra note 44 , art. 21 ; American Convention, supra note 44, art. 15.

150. See International Covenant, supra note 44, art. 11; American Convention, supra note 44, art. 7(7).

151. See CONST. ARG. (1994), art. 18. See also International Covenant, supra note 44, art. 14; American Convention, supra note 44, art. 8. 
habeas corpus rights, the provisions for liberty and security of the person are thin; ${ }^{152}$ and freedom of expression and religion clauses are generally narrower in scope than international counterparts. ${ }^{153}$ In sum, of the nineteen rights that Argentina's Constitution now shares with the international instruments, eleven are significantly less "muscular" than the international norms, without the nuances, subtleties, and refinements included in the international instruments. ${ }^{154}$ The "state of emergency" clause, which, despite being the target of constitutional reform, does not circumscribe the number or types of rights that may be suspended, potentially undermines the potency and scope of all constitutional protections. ${ }^{155}$ Thus, Argentina's Constitution would have remained in first group of constitutions in terms of substance.

Now consider the effect of Article 75(22). The Argentine Constitution is no longer a succinct document containing 110 constitutional provisions but rather a compendium of the constitutional text and the nine human rights treaties which, by virtue of their constitutional status, are effectively incorporated into the constitutional text. Therefore, every right, every privilege, every guarantee, that the anointed human rights treaties grant are part of Argentina's Constitution. Whereas some constitutions merely incorporate the spirit of human rights treaties ${ }^{156}$ and others more accurately reflect their scope and breadth, ${ }^{157}$ Argentina's Constitution takes a further step: wholesale incorporation of the treaties themselves. The Constitution now mirrors these select human rights treaties, identical in scope, form, and substance. In this sense, Argentina's actions are unique in South America and, arguably, the world. The 1994 constitutional reforms thus forced a shift along both comparative axes, substance and status, leaving the Argentine Constitution unparalleled in South America.

152. See ConST. ARG. (1994), arts. 18, 43. See also International Covenant, supra note 44, art. 9; American Convention, supra note 44, art. 7(1-6).

153. See ConST. ARG. (1994), art. 14. See also International Covenant, supra note 44, art. 18; American Convention, supra note 44, art. 12.

154. See Table 2 in the Appendix. A comparison of Columns 1 and 2 with Column 4 shows that the Argentine Constitution shares nineteen rights with the international instruments. Of these nineteen rights, eleven have "-" signs indicating that they are less expansive than their international counterparts.

155. See CONST. ARG. (1994), arts. 23, 29. See also International Covenant, supra note 44, art. 4; American Convention, supra note 44, art. 8.

156. See supra notes 55-78 and accompanying text.

157. See supra notes $79-86$ and accompanying text. 


\section{ASSESSING THE INTERNALIZATION STRATEGY: A SCOREBOARD}

Some human rights advocates laud Argentina's constitutionalization of human rights treaties as a bold step worthy of emulation. ${ }^{158}$ On the "ground," however, Argentina's internalization experiment is nascent and virtually invisible. The Argentine government continues to violate human rights; ${ }^{159}$ most lawyers have yet to unleash their new Constitution's potential; and the average individual is so skeptical of law and the possibility for law to vindicate any individual rights, let alone a new international human rights template, that the potential beneficiaries remain relatively ignorant of the constitutional changes. While Argentina internalized international law on paper, the nation clearly does not yet obey, let alone comply with, international human rights law. ${ }^{160}$

Why has this internalization strategy been largely ineffective? The answer lies, in great part, in transnational legal process theory, more specifically, with the transnational actors that drive transnational legal process. Transnational actors constitute and reconstitute interests, acting as antennae that reach into the depths of society, prodding corporal transformation. It is only logical that the number of transnational actors, or antennae, bears a direct relationship to the effectiveness of internalization strategies. Successful internalization

158. In particular, the Centro de Estudios Legales y Sociales (Center for Legal and Social Studies, or "CELS"), a leading Argentine human rights advocacy group, argues that Article 75(22) is a panacea to Argentina's human rights difficulties. See Interview with Martín Abregú, Director of CELS, in Buenos Aires, Arg. (June 24, 1997). See also infra notes 252-76 and accompanying text. In a series of lectures in June 1997, human rights advocates applauded the constitutionalization of human rights treaties. See Marcela Rodriguez, Woman's Rights Activist, Lecture to Summer Institute in International Law at Universidad de Palermo, Buenos Aires, Arg. (June 24, 1997) (describing Article 75(22) as a "good tool" for human rights activists); Raúl Alfonsín, Former President of Argentina, Lecture to Summer Institute in International Law at Universidad de Palermo, Buenos Aires, Arg. (June 25, 1997) (describing Article 75(22) as an "important" and "big step" and further describing Argentina's 1994 Constitution as the "Human Rights Constitution").

159. See Argentina: Death and Corruption, ECONOMIST, May 30, 1998, at 34 (discussing corruption, police brutality, and politicized judiciary); Calvin Sims, Argentina's Bereft Mothers: And Now, a New Wave, N.Y. TIMES, Nov. 18, 1997, at A4 (discussing the continuation of post"dirty war" police violence and killings, and noting the rise in number of police brutality cases and recent condemnation by the United Nations Human Rights Committee for the continued use of torture in police stations and prisons, despite Argentina's ratification of the U.N. Convention Against Torture); War on the Media in Argentina, N.Y.TIMES, Sept. 16, 1997, at A30; Anthony Faiola, Argentina Still Grappling with Oppressive Past, WASH. Post, Oct. 15, 1997, at A25 (discussing Argentina's restrictions on press freedom, as well as police, governmental, and judicial corruption); Ivan Briscoe, Argentine Murder Inquiry Points Finger at Police, GUARDIAN, Apr. 9, 1997, at 7 (discussing linkage between the police and the Mafia in the murder of a noted photographer); Jonathan Friedland, Police Give a Black Eye to Buenos Aires, WALL ST. J., Apr. 1, 1997, at A15 (discussing police corruption).

160. See supra notes 9-12 and accompanying text for discussion of the distinction between compliance and obedience. 
strategies-internalization strategies that breed a nation's desire to obey the law-are driven by the identity, enthusiasm, and relationships among transnational actors. Synergistic clusters of transnational actors-or epistemic communities ${ }^{161}$-are integral if international law is to permeate a nation effectively. Thus, a strategy that engages numerous transnational actors, from social, political and legal spheres, and that creates mutually reinforcing relationships between actors, is bound to affect a nation's psyche. Both the problems that Argentina's internalization strategy faces, and its incipient promises, may be traced to the extent to which various transnational actors participated in Article 75(22)'s epistemic community.

\section{A. The Problems}

1. The Constitutional Assembly: Where Are the Transnational Actors?

Some commentators argue that robust debate helps embed law in a nation's psyche. ${ }^{162}$ In terms of transnational legal process, select transnational actors may stimulate discussion about an international norm, which in turn may spur debate, thereby animating new transnational actors and, whether intentionally or inadvertently, propagating an international norm. The Constitutional Assembly provided a potential focal point for such discourse, and yet several transnational actors, most notably the human rights community, stood on the sidelines as the Constitutional Assembly codified Argentina's internalization strategy. These transnational actors were relatively disinterested prior to the Constitutional Assembly because the politics surrounding the Pacto de Olivos contaminated its legitimacy. In addition, stifling procedures and dynamics during the Constitutional Assembly effectively excluded these transnational actors, who were

161. See Koh, supra note 7, at 2656; Peter M. Haas, Introduction to Epistemic Communities and International Policy Coordination, 46 INT'LORG. 1, 3-4 (1992) (“An epistemic community is a network of professionals with recognized expertise and competence in a particular domain and an authoritative claim to policy-relevant knowledge within that domain or issue-area ... - Members of transnational epistemic communities can influence state interests either by directly identifying them for decision makers or by illuminating the salient dimensions of an issue from which the decision makers may then deduce their interests. The decision makers in one state may, in turn, influence the interests and behavior of other states, thereby increasing the likelihood of convergent state behavior and international policy coordination, informed by the causal beliefs and policy preferences of the epistemic community."). See also Symposium, International Law and International Relations Theory: Building Bridges, 86 AM. SOC'Y INT'L L. PROC. 167, 171 (1992) (remarks by Kenneth Abbott).

162. See generally Carlos Santiago Nino, The Constitution of Deliberative DEMOCRACY 144-86 (1996) (discussing the legitimating merit of robust debate of legal, particularly constitutional, issues in Argentina and citing numerous political scientists who support his view). 
already skeptical, from engaging in meaningful discourse. As a result, few transnational actors left the actual Constitutional Assembly with much energy or enthusiasm regarding Article 75(22).

\section{a. The Constitutional Assembly: the Prologue}

The Constitutional Assembly arrived with little fanfare or advance billing. ${ }^{163}$ The newspapers tended to bury stories about the Constitutional Assembly. Taxi drivers were unaware that the Constitutional Assembly was occurring. Many lawyers, including those involved in human rights issues, were skeptical and suspicious of the Constitutional Assembly and thus greeted its arrival in a nonchalant fashion.

Because of the fragility of law in Argentina, ${ }^{164}$ legal reform efforts are generally regarded with skepticism and caution. Skepticism of the Constitutional Assembly, however, was justifiably more intense. The Constitutional Assembly grew out of the Pacto de Olivos, ${ }^{165}$ which was little more than a political bargain: the Radical Party ${ }^{166}$ agreed to support amendments to the Constitution which would allow President Menem to run for a second term, and, in exchange, the Peronists ${ }^{167}$ supported broadening the scope of the reform effort. ${ }^{168}$ Thus, the Constitutional Assembly was tainted with political compromise and bargaining, leaving many members of the human rights communities doubting whether the Constitutional Assembly would be a serious forum in which to broker positive legal changes.

Furthermore, the Pacto de Olivos delineated several issues which the Constitutional Assembly would definitely address, as well as several

163. Many of the statements contained herein are impressional. The Constitutional Assembly began on May 25, 1994. I spent August 1994 in Argentina and attended some of the Constitutional Assembly's proceedings.

164. See NINO, supra note 29, at 47-48 (arguing that Argentina's disregard for the law has deep historical roots). For in-depth discussion of reasons for Argentina's lack of respect for the law, see generally CARLOS SANTIAGO NINO, UN PAíS AL MARGEN DE LALEY 53-136(1992). See also Andrew Arato, Forms of Constitution Making and Theories of Democracy, 17 CARDOZO L. REV. 191, 199 (1995) ("[I]n Argentina ... there is little constitutionalism."); Irwin P. Stotzky, The Fragile Bloom of Democracy, 44 U. MIAMI L. REV. 105 (1989).

For general discussion of the weak state of constitutionalism in Latin America, see Keith S. Rosenn, The Success of Constitutionalism in the United States and Its Failure in Latin America: An Explanation, 22 U. MIAMIINTER-AM. L. REV. 1 (1990); Keith Rosenn, Federalism in the Americas in Comparative Perspective, 26 U. MIAMI INTER-AM. L. REV. 1 (1994). See also Rohter, supra note 24, at 1.

165. See supra notes $37-42$ and accompanying text.

166. The Radical Party is the more liberal of the two main parties. At the time, ex-President Alfonsín was at its helm. See supra note $\mathbf{3 0}$ and accompanying text.

167. The Peronist Party is now the more conservative of the two parties. President Menem is a member of the Peronist Party. See supra note 38 and accompanying text.

168. See Vega, supra note 38 , at $2-5$. As evidence of this political compromise, most of the topics included in the mandatory list of reforms concern executive powers and the length of the presidential term. See supra note 40. 
areas which the Constitutional Assembly might address. ${ }^{169}$ Human rights, however, was not on either list. ${ }^{170}$ In the build-up to the Constitutional Assembly, there was little reason for the human rights community to become animated, for human rights were ostensibly outside the purview of constitutional reform.

\section{b. The Constitutional Assembly Proceedings}

During the Constitutional Assembly itself, the absence of human rights is striking. In the record, I expected to find passionate debate in support, fueled by the human rights community and the specter of the military's human rights abuses. ${ }^{171}$ Instead, debate was flat and antiseptic, devoid of substantive discussion of human rights concerns. ${ }^{172}$ I attribute this to the procedures and political dynamics of the Constitutional Assembly which exacerbated the human rights community's indifference by effectively constricting its discursive

169. See supra notes 40-42 and accompanying text.

170. Admittedly, a few of the issues on the "optional" list, supra note 41 , tangentially broached particular human rights norms. For example, one issue on the "optional" list was habeas corpus and direct constitutional appeals, an area that would potentially bolster criminal defendant rights. Other issues for review were "indigenous communities" and "preservation of the environment." The former is a concern of the International Covenant. See International Covenant, supra note 44, art. 27. The latter is the subject of international treaties. See, e.g., International Covenant on Economic, Social and Cultural Rights, supra note 44, art. 12(2)(b). However, there was no "human rights committee," where a full panoply of issues could be discussed, codified, and/or prioritized.

171. See supra note 29 and accompanying text for discussion of human rights abuses during the military dictatorship.

172. The Constitutional Assembly's limited discussion of the military's human rights abuses took place in rather guarded, controlled terms. Given the extent and horrific nature of the human rights abuses, one could imagine impassioned speeches about human rights and the need to take extraordinary measures to protect them. The Record of the Constitutional Assembly reveals that very few members even discussed Argentina's human rights record. Those that did were rather dispassionate in their discussions. See, e.g., REC. CONST. ASSEMBLY No. 19, June 17, 1994, 11:00 A.M., at 784 (statement of Teresita B. Serrat) (veiled reference to the military's human rights abuses, while referencing democratic nation's duty to respect human rights); REC. CONST. ASSEMBLY No. 22, June 22, 1994; 1:00 P.M., at 930 (statement of Mabel G. de Marelli \& Mario Dei Castelli) (proposed amendment to include executive oversight in response to "the historical experience of the Argentine people" that occurs when "the state does not promote as much respect for human rights"); REC. CONST. ASSEMBLY No. 26, June 23, 1994, 1:30 P.M., at 1255 (statement of Juan C. Hitters). Delegates did not delve into the substance of or reasons for human rights. Instead, they merely stated that human rights were "important" and that constitutionalization would showcase their import. See, e.g., REC. CONST. ASSEMBLY No. 16, June 15, 1994, 3:00 P.M., at 611 (statement of Jorge D. Amena, Susana S. de De María, María C. Allenano \& Augusto Acuña); REC. CoNST. ASSEMBLY No. 19, June 17, 1994, 11:00 A.M., at 784 (statement of Teresita B. Serrat); REC. CONST. ASSEMBLY No. 20, June 21, 1994, 11:00 A.M., at 832 (statement of María Bercoff); REC. CONST. ASSEMBLY No. 21, June 21, 1994, 6:00 P.M., at 849 (statement of Rodolfo O. Ponce de León); REC. CoNST. ASSEMBLY No. 21, June 21, 1994, 6:00 P.M., at 861 (statement of Hector J. Carattoli); REC. CONST. ASSEMBLY NO. 31, June 24, 1994, 12:00 P.M., at 1701 (statement of Enrique de Vedia); REC. CONST. ASSEMBLY No.33, June 24, 1994; 2:00 P.M., at 1840 (statement of Emilia Juañuk \& Julio Humada). 
space. Thus, the human rights community remained, for the most part, aloof and disinterested during most of the Constitutional Assembly.

The Constitutional Assembly charged the Treaty Commission with jurisdiction over human rights concerns. ${ }^{173}$ The focus of this Commission was not human rights, but rather, the juridical status of international treaties ${ }^{174}$ and Mercosur. ${ }^{175}$ Human rights treaties gained special constitutional standing, not necessarily because of their substance, but because they were a symbolic break from the past and thus enhanced Argentina's reputation and standing vis-à-vis Mercosur and other economic integration efforts. ${ }^{176}$ Thus, human rights issues arose incidental to these other concerns, woven into the Constitution

173. See supra note 43 and accompanying text. The Constitutional Assembly discussed the treaty issue at length in the following parts of the Constitutional Assembly's record: REC. CONST. ASSEMBLY, Nos. 3, 7, 10, 15, 16, 17, 19-22, 24-26, 28, 31, 33, 35 (1994).

174. As noted above, Argentina's pre-1994 Constitution was somewhat ambiguous with regard to the status of international treaties, particularly concerning the potential conflict between Article 27 and Article 31. See supra notes 102-07 and accompanying text. Many delegates viewed Article 75(22) as a mere opportunity to clarify this hyper-legal ambiguity. See REC.CONST. ASSEMBLY No. 19, June 17, 1994, 11:00 A.M., at 786 (statement of Guillermo E. Estévez Boero, Alfredo P. Bravo \& Norberto L. La Porta); REC. CoNST. AsSEMBLY No. 22, June 22, 1994, 1:00 P.M., at 88 (statement of Augusto J.M. Alasino); REC. CONST. ASSEMBLY No. 24, June 22, 1994, 5:00 P.M., at 1013 (statement of Alberto A. Natale, Pablo A. Cardinale \& Carlos A. Caballero Martín); REC. CONST. AsSEMBLY No.26, June 23, 1994, 1:30 P.M., at 1255 (statement of Juan C. Hitters); REC. CONST. ASSEMBLY No. 35, June 24, 1994; 5:30 P.M., at 1975 (statement of Alberto E. Balestrini).

Other delegates argued that constitutionalization was necessary to comport with obligations assumed under the Vienna Convention on the Law of Treaties. See REC. CONST. ASSEMBLY No. 19, June 17, 1994, 11:00 A.M., at 786 (statement of Guillermo E. Estevez Boero, Alfredo P. Bravo \& Norberto L. La Porta); REC. CONST. ASSEMBLY No. 21, June 21, 1994, 6:00 P.M., at 848 (statement of Rodolfo O. Ponce de León); REC. CONST. ASSEMBLY No. 21, June 21, 1994, 6:00 P.M., at 861 (statement of Hector J. Carattoli); REC. CONST. ASSEMBLY No. 31, June 24, 1994, 12:00 P.M., at 1701 (statement of Enrique de Vedia). See also Vienna Convention on the Law of Treaties, opened for signature May 23, 1969, art. 27, U.N. GAOR, 1st Sess., U.N. Doc. A/CONF.39/27 (1969) ("A party may not invoke the provisions of its internal law as justification for its failure to perform a treaty.").

Others believed that constitutionalization was necessary to comport with Article 2 of the American Convention, which requires that states conform domestic law to international obligations. See REC. CONST. AsSEMBLY No. 21, June 21, 1994, 6:00 P.M., at 849 (statement of Rodolfo O. Ponce de León). See also American Convention, supra note 44, art. 2.

175. Mercosur is a common market among Argentina, Brazil, Paraguay and Uruguay, based on coordinated reductions in customs tariffs, elimination of non-tariff barriers, a common external tariff, and macroeconomic policy coordination. See Treaty Establishing a Common Market (Treaty of Asuncion), Arg.-Braz.-Para.-Uru., Mar. 26, 1991, 30 I.L.M. 1041 (1991); Additional Protocol to the Treaty of Asuncion on the Institutional Structure of Mercosur ("Protocol of Ouro Preto"), Dec. 17, 1994, 34 I.L.M. 1244 (1995) (creation of Mercosur's institutional structure, including Common Market Council, Common Market Group, Mercosur Trade Commission, Joint Parliamentary Commission, Economic and Social Consultative Forum, and Mercosur Administrative Secretariat); Protocol of Brasilia for the Settlement of Disputes, Dec. 17, 1996, 36 I.L.M. 691 (1997) (creation of a Dispute Settlement System). See generally Thomas Andrew O'Keefe, An Analysis of the Mercosur Economic Integration Project from a Legal Perspective, 28 INT'L LAW. 439 (1994).

176. For a thorough discussion of Mercosur's prominent role in the debates regarding Article 75(22), see infra notes 245-51 and accompanying text. 
concomitant to more general consideration of international treaties. In a body charged with finding the proper status for international treaties, in particular integration treaties, human rights were an appendage. The human rights community, therefore, did not have a clear, uncluttered forum in which to debate substantive human rights issues. Whereas the human rights community could have been - should have been-Article $75(22)$ 's most vociferous ally, their spirit remained largely untapped because human rights themselves remained on the periphery of constitutional debate.

The mode of internalization - wholesale constitutionalization of entire human rights treaties-was perhaps the noxious by-product of the relegation of human rights concerns to a relatively disinterested committee. Recall that Argentina, as opposed to many South American countries, ${ }^{177}$ did not borrow clauses from human rights treaties to develop and modernize the individual rights portion of its Constitution. ${ }^{178}$ Instead, Argentina transplanted in toto entire human rights treaties, creating a type of mega-constitutional appendage. With the limited exception of delegates who championed women's rights, ${ }^{179}$ delegates were not engaged in debate regarding particular individual rights, but rather, debated whether to annex entire treaties to the Constitution. The presumption throughout the Argentine Constitutional Assembly was "all or nothing"-either incorporation of all or none of the principles contained in any one, or several, human rights treaties. ${ }^{180}$

177. See supra notes 50-86 and accompanying text.

178. See supra notes $137-55$ and accompanying text.

179. A few of the delegates focused on treaties dealing with women's/children's rights. See REC. CONST. ASSEMBLY No. 3, June 3, 1994, 6:30 P.M., at 163 (concerned with equality, discrimination, and enhancing enforcement of rights found in the Convention on the Elimination of all Forms of Discrimination Against Women); REC. CONST. ASSEMBLY No. 15, June 14, 1994, 10:00 P.M., at 575 (statement of Pedro Perette, Susana Melo, Humberto E. Salum \& Luis M. Aguilar Torres); REC. CONST. AssEMBLY No. 17, June 15, 1994, 9:30 P.M., at 670 (statement of Cecilia Lipsyzc, Juan Schroeder, María Sanchez, Rina Leiva, Daniel García, Adriana Puiggrós \& Ana M. Pizzurno) (proposed constitutionalization only of women's rights treaties); REC. CONST. ASSEMBLY No. 19, June 17, 1994, 11:00 A.M., at 784 (statement of Teresita B. Serrat) (anti-abortion rhetoric veiled in discussion of importance of right to life and women's rights); REC. CONST. ASSEMBLY No. 22, June 22, 1994; 1:00 P.M., at 910 (statement of Maria T. Méndez, Dora Rocha de Feldman, María L Casari de Alarcia \& Elso G. González) (detailed discussion about the Convention on the Elimination of all Forms of Discrimination Against Women and the desire to constitutionalize this treaty).

Women's rights groups had a multi-issue agenda at the Constitutional Assembly, with their priorities being Article 37, which granted women the right to significant representation in political parties, and Article $75(23)$, which potentially could have banned abortions but instead set forth a comprehensive social security regime. Thus, women's groups' advocacy on behalf of Article 75(22) may have been incidental to these other concerns.

180. Of sixteen proposals to constitutionalize human rights treaties, fourteen even failed to differentiate among human rights treaties and recommended constitutionalization of all of them. See REC. CONST. ASSEMBLY No. 16, June 15, 1994, 3:00 P.M., at 34; REC. CONST. AsSEMBLY No. 17, June 15, 1994, 9:30 P.M., at 679-81 (statement of Eduardo S. Barcesat); REC. CONST. ASSEMBLY No. 19, June 17, 1994, 11:00 A.M., at 779 (statement of María N. Meana García, 
While this type of wholesale incorporation may have been the most efficient mode, it was not the most effective. Those few human rights discussions that did occur took place in undifferentiated terms. There was no discussion regarding the death penalty-discussion that could have prompted the support of criminal defendant rights groups; there was no discussion of the freedom of speech-discussion that could have motivated ACLU-like, individual liberties groups; and there was no discussion regarding the rights of indigenous populations-discussion that could have tapped into national and international non-governmental organizations. Different public interest groups may have been engaged if they had perceived an opening in the debate for prioritization, hierarchy, and differentiation among various rights. These groups could have become transformative transnational actors, entrenched in the ultimate success of Article 75(22). Instead, the human rights community, for the most part, remained aloof.

Nevertheless, Article 75(22) ultimately did differentiate among human rights treaties, granting some constitutional status while granting others mere supra-statutory status. ${ }^{181}$ This differentiation, however, was not the result of meaningful prioritization of some human rights and thus did not transform potentially interested parties into engaged

Pablo Verani, Horacio Massaccesi \& Santiago A. Hernandez); REC. CONST. AsSEMBLY No. 20, June 21, 1994, 11:00 A.M., at 832 (statement of Maria Bercoff); REC. CONST. ASSEMBLY No. 20, June 21, 1994, 11:00 A.M., at 835 (statement of Ana M. Dressino); REC. CONST. ASSEMBLY No. 21, June 21, 1994, 6:00 P.M., at 848 (statement of Nilda Romero); REC.CONST. ASSEMBLY No. 21, June 21, 1994, 6:00 P.M., at 876 (statement of Angel Prado); REC. CONST. ASSEMBLY No. 22, June 22, 1994, 1:00 P.M., at 888 (statement of Augusto J.M. Alasino); REC. CONST. ASSEMBLY No. 22, June 22, 1994, 1:00 P.M., at 898 (statement of Juan F. Armagnague); REC. CONST. ASSEMBLY No. 22, June 22, 1994, 1:00 P.M., at 910 (statement of María T. Méndez, Dora Rocha de Feldman, María L Casari de Alarcia \& Elso G. González); REC. CONST. ASSEMBLY No. 24, June 22, 1994, 5:00 P.M., at 1071 (statement of Juan M. Pedersoli, Olga C. Abraham \& Pascual A. Rampi); REC. CONST. ASSEMBLY No. 25, June 22, 1994, 8:30 P.M., at 1120; REC. CONST. ASSEMBLY No. 25, June 22, 1994, 8:30 P.M., at 1138 (statement of Alicia Oliveira \& Eugenio R. Zaffaroni); REC. CONST. ASSEMBLY No. 33, June 24, 1994, 2:00 P.M., at 1822 (statement of Enrique G. Cardosa); REC. CONST. ASSEMBLYNo.33, June 24, 1994; 2:00 P.M., at 1840 (statement of Emilia Juañuk \& Julio Humada).

The following proposals recommended constitutionalization of particular types of human rights treaties: see REC. CONST. ASSEMBLY No. 17, June 15, 1994, 9:30 P.M., at 670 (statement of Cecilia Lipsyzc, Juan Schroeder, María Sanchez, Rina Leiva, Daniel García, Adriana Puiggrós \& Ana M. Pizzurno) (only women's rights treaties); REC. CONST. ASSEMBLY No. 19, June 17, 1994, 11:00 A.M., at 784 (statement of Teresita B. Serrat) (constitutionalization of any treaty including right to life provision and addressing discrimination).

181. See supra notes $44-48$ and accompanying text. While nine human rights treaties are on par with the Constitution, other human rights treaties merely stand superior to domestic statutes but inferior to the Constitution. The constitutional provision granting all human rights treaties, at a minimum, supra-statutory status codifies the Supreme Court's decision in "Ekmekdijàn," CSJN (1992). Those human rights treaties which do not enjoy constitutional standing nonetheless further enforcement of human rights because, in standing superior to domestic law, they are not susceptible to abrogation by a subsequent statute. See supra note 89 and accompanying text for an explanation of the last-in-time rule. However, constitutional provisions could circumscribe and potentially nullify provisions in human rights treaties that do not enjoy constitutional standing. 
transnational actors. After the Commission on Integration and International Treaties received recommendations and comments, it drafted a proposal which, reflecting the sentiments discussed above, ${ }^{182}$ constitutionalized all the human rights treaties which Argentina had ratified. ${ }^{183}$ Yet, Article 75(22) ultimately constitutionalized only nine

182. See supra note 180 and accompanying text for discussion of proposals regarding breadth of constitutionalization.

183. See CONVENCIÓN NACIONAL CONSTITUYENTE, DictaMen DE COMISIÓN DE INTEGRACIÓN Y TRATADOS INTERNACIONALES A LA COMISIÓN DE REDACCIÓN NO. 7 (July 13, 1994) [hereinafter DICTAMEN No. 7] ("International treaties regarding human rights, that are ratified, enjoy constitutional standing, and the rights, liberties and guarantees that they sanctify are considered self-executing") (translations by the Author).

The Commission also listed all human rights treaties that Argentina had ratified, noting that the list was not exclusive and could be amended as Argentina ratified additional treaties. See CONVENCIÓN NaCional CONSTITUYENTE, Dictamen DE COMISIÓN DE INTEGRACIÓN Y TRATADOS INTERNACIONALES A LA COMISIÓN DE REDACCIÓN No. 11 (July 13, 1994). The list, in chronological order of Argentine ratification, includes the following: Universal Declaration, supra note 44; American Convention on the Rights and Duties of Man, supra note 44; Convention on the Prevention and Punishment of the Crime of Genocide, supra note 44; Geneva Convention on International Humanitarian Law, adopted Aug. 12, 1949, 6 U.S.T. 31 14, 3217, 3316, 3516, 75 U.N.T.S. 31, 85, 135, 287 (entered into force Oct. 21, 1950); Convention for the Suppression of the Traffic in Persons and of the Exploitation of the Prostitution of Others, opened for signature Mar. 21, 1950, 96 U.N.T.S. 271; Convention on the Status of Refugees, 189 U.N.T.S. 150 (entered into force Apr. 22, 1954); Convention on the Political Rights of Women, 193 U.N.T.S. 135 (entered into force July 7, 1954); Supplemental Convention on the Abolition of Slavery, the Slave Trade, and Institutions and Practices Similar to Slavery, 226 U.N.T.S. 3 (entered into force Apr. 30, 1957); Convention Against Discrimination in Education, 429 U.N.T.S. 93 (entered into force Dec. 14, 1960); International Convention on the Elimination of All Forms of Racial Discrimination, supra note 44; International Covenant (including Protocol), supra note 44; International Covenant on Economic, Social, and Cultural Rights, supra note 44; American Convention, supra note 44; Abolition of Forced Labor Convention, ILO No. 105, 320 U.N.T.S. 291 (entered into force Jan. 17, 1959); Convention on the Nationality of Married Women, G.A. Res 1040(XI), 11th Sess. (entered into force Jan. 29, 1957); Convention on Consent to Marriage, Minimum Age for Marriage, and Registration of Marriages, 521 U.N.T.S. 231 (entered into force Dec. 9, 1964); Declaration of the Rights of Disabled Persons, G.A. Res. 3447(XXX), U.N. GAOR, 30th Sess., Supp. No. 34, U.N. Doc. A/10034 (1975); Geneva Convention for the Amelioration of the Condition of Wounded, Sick and Shipwrecked Members of the Armed Forces at Sea, 6 U.S.T. 3217, 75 U.N.T.S. 85 (entered into force Oct. 21, 1950); Geneva Convention on the Treatment of Prisoners of War, 6 U.S.T. 3316, 75 U.N.T.S. 135 (entered into force Oct. 21, 1950); Geneva Convention Relative to the Protection of Civilian Persons in Times of War, 6 U.S.T. 3516, T.I.A.S. No. 3365, 75 U.N.T.S. 287 (entered into force Oct. 21, 1950); Protocol Additional to the Geneva Conventions of 12 August 1949 and Relating to the Protection of Victims of International Armed Conflicts, U.N. Doc. A/32/144, Annex I, 16 I.L.M. 1391 (entered into force Dec. 7, 1978); Convention between the American Republics regarding the Status of Aliens in their Respective Territories, signed Feb. 20, 1928, 46 Stat. 2753, T.S. No. 815, 132 L.N.T.S. 301; Convention on the Nationality of Women, signed Dec. 26, 1933, 49 Stat. 2957 (entered into force Aug. 29, 1934); Inter-American Convention on the Granting of Civil Rights to Women, Pan. Am. Union L. \& Treaty Series No. 27; Inter-American Convention on the Granting of Political Rights to Women, opened for signature May 2, 1948, 27 U.S.T. 3301, T.I.A.S. No. 8365 (entered into force Mar. 17, 1949); International Convention on the Suppression and Punishment of the Crime of Apartheid, opened for signature Nov. 30, 1972, G.A. Res. 3068, U.N. GAOR, 28th Sess., Supp. No. 30, U.N. Doc A/9030 (1974) (entered into force July 19, 1976); International Convention on the Elimination of All Forms of Discrimination Against Women, supra note 44; Convention Against Torture and Other Cruel, Inhumane, Degrading Treatment or Punishments, supra note 44; Interamerican Convention for 
human rights treaties. ${ }^{184}$ What transpired to transform the Treaty Commission's inclusive proposal into the relatively restrictive text that became Article 75(22)? Finally, was there debate and discussion regarding prioritization of rights? We will never know and can only speculate. The Constitutional Assembly's Comisión de Redacción (Drafting Committee), comprised primarily of delegates from the "pactista" parties, ${ }^{185}$ made final drafting decisions behind closed doors, imperviously sequestered from the influence or participation of any NGOs, including human rights organizations. In fact, the Drafting Committee itself grew from political compromise, designed to be the "true space for political and ideological control on the part of the 'pactista' parties." 186 While some commentators speculate on the rationale behind the Drafting Committee's substantial paring down of the proposal, ${ }^{187}$ there is no record of its members' discussions and no hard evidence of their reasoning. At the moment when the Constitutional Assembly could have directed the debate on human rights from the generic to the specific, from a monolithic conception to a somewhat differentiated discussion of the merit of some treaties vis-àvis the merit of others, from a sterile, nonengaging discourse to an animating, participation-invoking discussion, the debate became the exclusive realm of the Drafting Committee.

The Drafting Committee's closed door decisions also hindered Article 75(22)'s ability to tap transnational actors interested more generally in international law issues. The question of whether treaties are self-executing or non-self-executing is integrally related to the juridical status of such treaties. ${ }^{188}$ Most countries resolve this issue in the domestic courts, as parties attempt to invoke rights or obligations

the Prevention and Punishment of Torture, supra note 44; and Convention on the Rights of the Child, supra note 44.

The minority proposal coming from the Treaty Commission was the following: "Once ratified and published, international treaties will prevail over the domestic laws of the Nation." DICTAMEN No. 7, supra note 183.

See also Graham \& Cafiero, supra note 107, at 28 (discussing proposal emanating from Treaty Commission).

184. See supra note 44 and accompanying text.

185. "Pactista" references the parties to the Pacto de Olivos. See supra notes 37-39 and 165-67 and accompanying text.

186. See Vega, supra note 38, at 11.

187. See Graham \& Cafiero, supra note 107, at 28 (suggesting that the Drafting Committee chose to constitutionalize those treaties that were universal, that bore particular significance to Argentina's recent history, and that came to the aid of those members of society that had been historically underrepresented).

188. See supra note 35 and accompanying text. 
contained in various treaties. ${ }^{189}$ Is Argentina required to enact enabling legislation, other than the ratification instrument, before international treaties, including those which enjoy constitutional status, are deemed operable law? Many delegates proposed explicit clarification of this issue in the Constitution itself. ${ }^{190}$ Others viewed constitutionalization as tantamount to creating a group of self-executing treaties and thus proposed constitutionalization as a remedy to extant ambiguity. ${ }^{191}$ The Treaty Commission's ultimate proposal explicitly granted self-executing status to the rights contained in the anointed human rights treaties. ${ }^{192}$ The Drafting Committee, however, removed all references to the selfexecuting issue from the Constitution's text, thus leaving the new Constitution as ambiguous as the former. ${ }^{193}$ While most commentators believe that the rights contained in constitutionalized treaties-indeed,

189. In the United States, "[w]hether an agreement is to be given effect without further legislation is an issue that a court must decide when a party seeks to invoke the agreement as law." RESTATEMENT, supra note 35, \$111 cmt. h. In Asakura v. Seattle, 265 U.S. 332 (1924), a Japanese alien challenged a city ordinance allowing only United States citizens to obtain pawnbroking licenses by invoking a provision of a treaty between the United States and Japan. The Court invalidated the ordinance on the grounds that the treaty was self-executing, noting that the treaty "operates of itself without the aid of any legislation ... and it will be applied and given authoritative effect by the courts." Id. at 341. For an example of the Court's finding a treaty to be non-self-executing, see Cameron Septic Tank Co. v. City of Knoxville, 227 U.S. 39 (1913).

190. Many delegates submitted proposals which explicitly stated that human rights treaties bearing constitutional status would be self-executing. See REC. CONST. ASSEMBLY No. 17, June 15, 1994, 9:30 P.M., at 654 (statement of Elisa M.A. Carrio); REC. CONST. ASSEMBLY No. 20, June 21, 1994, 11:00 A.M., at 832 (statement of Maria Bercoff); REC. CONST. ASSEMBLY No. 22, June 22, 1994, 1:00 P.M., at 898 (statement of Juan F. Armagnague); REC. ConsT. ASSEMBLY No. 25, June 22, 1994, 8:30 P.M., at 1120 (statement of María Z.. Lucero); REC. CONST. ASSEMBLY No. 33, June 24, 1994, 2:00 P.M., at 1822 (statement of Enrique G. Cardosa).

Other delegates proposed that all international treaties are self-executing. See REC. CONST. ASSEMBLY No. 19, June 17, 1994, 11:00 A.M., at 786 (statement of Guillermo E. Estevez Boero, Alfredo P. Bravo \& Norberto L. La Porta).

191. See ReC. CONST. ASSEMBLY No. 21, June 21, 1994, 6:00 P.M., at 848 (statement of Rodolfo O. Ponce de León) (after reviewing Argentine, provincial, and international jurisprudence regarding self-executing/non-self-executing issue, concluding that there is a strong presumption that international treaties are self-executing, believes that constitutionalization bolsters this presumption, and further drafts a constitutional amendment that would embody this presumption); REC. CONST. ASSEMBLY No. 31, June 24, 1994, $12: 00$ P.M., at 1701 (statement of Enrique de Vedia) (raising international treaties above domestic law will transform them into self-executing documents); REC. CONST. ASSEMBLY NO. 33, June 24, 1994, 2:00 P.M., at 1840 (statement of Emilia Juañuk \& Julio Humada) (constitutionalization will make treaties self-executing).

192. See DICTAMEN No. 7, supra note 183 ("International treaties regarding human rights, that are ratified, enjoy constitutional standing, and the rights, liberties and guarantees that they sanctify are considered self-executing".).

193. The current constitutional text does not make any reference to the self-executing/nonself-executing issue. See supra notes $44-47$ and accompanying text. See also Graham \& Cafiero, supra note 107, at $42-46$ (noting that the Drafting Committee rejected the Treaty Commission's proposal). 
in all human rights treaties-are self-executing, ${ }^{194}$ the ambiguity remains left to the courts to resolve. ${ }^{195}$

What are the implications in terms of our transnational actor analysis? Numerous transnational actors care deeply about the selfexecuting/non-self-executing dichotomy. Virtually any person or entity with international contacts will have a position-a stake-in the resolution of the self-executing dilemma; any business person who has an interest in international commercial treaties, any exporter who has a stake in immediate enforcement of international trade agreements, and any prosecutor who would like immediate enforcement of Argentina's extradition agreements. The Treaty Commission hoped to entrench a partial solution in Article 75(22). This would have linked many of these generalized international interests to the ultimate fate of Article 75(22). Instead, the Drafting Committee sanitized the ultimate provision and thus left these potential transnational actors to fight their battles elsewhere, maybe in the courts or in the legislature, but definitely outside the epistemic space granted to Article 75(22).

The Constitutional Assembly-through its delegation of human rights issues to a committee dedicated generically to international treaties and integration, the concomitant presumption that human rights would be internalized in a wholesale manner, and the relegation of final decisions to a closed-door, non-participatory Drafting Committeemissed a ripe opportunity to create a loyal cadre of transnational actors from the human rights community, as well as from those with more generalized international law-related interests. Nevertheless, internalization of international law is a dynamic process. The disenfranchisement of the human rights community during the codification of Argentina's internalization strategy does not preclude them from entering Article 75(22)'s epistemic space at some point in the future. In fact, as will be discussed herein, human rights NGOs are currently working to anchor Article 75(22) in Argentina's legal discourse and practice. Nonetheless, Argentina's internalization strategy would have had powerful propagating momentum had the human rights community left the Constitutional Assembly as energized transnational actors.

194. See Graham \& Cafiero, supra note 107, at 42-46 (arguing that the Drafting Committee did not materially alter the proposals of the Treaty Commission and that human rights treaties are self-executing).

195. See, e.g., "Ekmekdjián," CSJN (1992) (stating that an international norm is selfexecuting when it does not require Congress to establish additional institutions to support the norm). See also Advisory Opinion OC-7/86, Inter-Am. C.H.R., ser. A, no. 7 (Aug. 29, 1986) (noting that Articles 1 and 2 of the American Convention, requiring states to recognize and guarantee all rights included therein, create a strong presumption that these rights are selfexecuting). 
2. The Domestic Courts in the Wake of the Constitutional Assembly: Passive Transnational Actors

The Argentine domestic court system is perhaps the essential link between the constitutional text and actual protection of human rightsbetween the domestic and international legal communities. To date, however, the Argentine courts have been relatively passive transnational actors, failing to harness the potency and breadth of international human rights law. The following section will trace the Supreme Court's, as well as some lower courts', use of their new constitutional tools (i.e., human rights treaties) in deciding cases. The survey concludes that courts have not yet mobilized to become potent transnational actors in Article 75(22)'s epistemic community. Without energy, enthusiasm, activism, and creativity, the courts will not effectively absorb international law into Argentina's domestic legal community.

\section{a. The Supreme Court}

In its initial confrontation with Article 75(22), the Court appears as an energetic soldier. In Giroldi, the Court contemplated the constitutionality of appellate procedures in criminal courts. ${ }^{196}$ The Court ultimately concluded that the procedures were unconstitutional pursuant to a provision of the American Convention which mandates that convicted criminal defendants have the right to an appeal. ${ }^{197}$ By framing the case as one of constitutional import, yet relying on the American Convention for ultimate legal support, the Court consecrated the constitutional status of international human rights treaties. More important, in relying on the American Convention as its legal crutch, the Court ruminated on the meaning of Article 75(22) and concluded that international jurisprudence, specifically the opinions of the InterAmerican Court of Human Rights, "should serve as a guide for the interpretation" of the Convention's provisions. ${ }^{198}$ Thus, the Court concluded that the 1994 constitutional reform imported not only the text of several human rights treaties but also attendant interpretive jurisprudence.

While Giroldi suggests an active role for the Court, in its subsequent cases, the Supreme Court recoiled, becoming a rather

196. See "Giroldi, Horacio David," CSJN (1995) (copy on file with Author) (translations of the case are by the Author).

197. See American Convention, supra note 44, art. 8(h) ("During the [criminal] proceedings, every person is entitled, with full equality, to the following minimum guarantees: the right to appeal the judgment to a higher court.").

198. "Giroldi," CSJN (1995), I 11. In reality, the Court had been using international jurisprudence as an interpretive guide long before the Giroldi decision. See, e.g., "Ekmekdjián," CSJN (1992), at 17. Thus, Giroldi is a reaffirmation of past practice in a postconstitutional reform climate. 
passive, detached actor. ${ }^{199}$ In these cases, the Court generally recognized the newly anointed position of human rights treaties. ${ }^{200}$ While the Court cited international conventions, its decisions neither interpreted their meaning, pursuant to Giroldi, nor decisively relied on international law in reaching its conclusions ${ }^{201}$-instead, international law provided a mere cushion for the decision. In each instance, the Court could have animated international human rights treaties, interpreting relevant conventional law and catapulting that law into the forefront of constitutional jurisprudence. The Court, however, conservatively avoided this challenge. As a result, international human rights law lies more or less latent. ${ }^{202}$

199. See "H.C.S.," CSJN (1995) (copy on file with Author) (upholding the legality of forced blood samples to prove paternity); "Viaña, Roberto," CSJN (1995) (copy on file with Author) (granting habeas corpus petition after holding imprisonment of local legislator for defamatory statements to be illegal); "Gabrielli, Mario Carlos," CSJN (1996) (copy on file with Author) (translations of the case are by the Author) (upholding legality of discharge of soldier for failure to inform superiors of marriage pursuant to military law).

200. See "Gabrielli," CSJN (1996), I 5 ("Besides, the 1994 Constitutional Reform has incorporated as part of the constitutional hierarchy ... the rights consecrated in certain human rights treaties"); "H.C.S.," CSJN (1995), I 13 (noting that Article 75(22) grants the Convention on the Rights of the Child constitutional hierarchy).

201. In H.C.S., a case involving forced blood samples to prove paternity, the Court relied on three sources of law related to the right to privacy and the right against self-incrimination: 1) domestic statutes (the Court cites various provisions of the Penal and Civil Codes, especially those that concern intrusions on individual liberty and privacy, as well as those dealing with documenting birth and national identity); 2) relevant constitutional provisions (including Article 18, which protects individuals from forced self-incrimination, and Article 19, which states "The private actions of men that in no way offend public order or morality, nor injure a third party, are reserved only to God and are exempt from the authority of the magistrates"); and 3) Article 7 of the Convention on the Rights of the Child (stating that children have the right to know their parents and to be cared for by them). The Court expends little energy developing the Convention-based law, and the Convention is not a decisive arbiter of the Court's decision. See "H.C.S.," CSJN (1995).

In Viaña, a case dealing with the imprisonment of a local legislator for defamatory statements, the Court examines the law pertaining to freedom of expression. While the Court cites the American Convention (see American Convention supra note 44, art. 13), it relies on domestic statutes and the Constitution in reaching its decision to grant the habeas petition. See "Viaña," CSJN (1995).

In Gabrielli, a soldier was discharged under military law for failure to inform superiors of his marriage. The Court upheld the military code provision. While it lists the international treaties that grant individuals the right to marry (see Universal Declaration of Human Rights, supra note 44, art. 16(1); International Covenant, supra note 44, art. 23; American Convention, supra note 44 , art. 17), the Court relies on limiting domestic case law and statutes that hold that the military law requiring soldiers to inform superiors of marriage is reasonable. See "Gabrielli," CSJN (1996).

202. One may counter that the U.S. Supreme Court explicitly avoids constitutional decisions and that the Argentine Supreme Court, in avoiding decisions based on international treaties (the Constitution), was merely following such practice. Yet, the United States is not haunted by a recent history of deprivation of fundamental rights, as Argentina is. The Argentine Supreme Court, if it had embraced the Constitution and human rights treaties, could have played an important role, not only in Article 75(22)'s epistemic community, but also in the consecration of fundamental rights that is crucial to Argentina's distancing itself from its past. 
Worse, some recent opinions suggest that the Court may become a rogue member of Article 75(22)'s epistemic community. The Court has recently become more aggressive in its use of human rights treaties. In doing so, however, it has twisted international law against individual petitioners, hindering rather than helping compliance efforts. In Bramajo, the Court entertained the legality of a lengthy, pretrial preventative detention. ${ }^{203}$ The American Convention grants individuals the right to "be brought promptly before a judge or other officer authorized by law to exercise judicial power and shall be entitled to a trial within a reasonable time ...."204 Recognizing that the American Convention enjoys constitutional status and that Giroldi authorizes the Court to use international jurisprudence as an interpretational aid, ${ }^{205}$ the Court relied on a 1989 Inter-American Commission on Human Rights opinion pertaining to the length of pretrial detention in Argentina. ${ }^{206}$ According to the Commission, local judges should be the arbiters of the "reasonableness" of a pretrial detention. ${ }^{207}$ Interpreting the Commission's decision as allowing "reasonableness" to be determined solely according to domestic standards, the Court relied on its own case law in upholding the lower court's decision to sanction the constitutionality of a three-year pretrial detention. Consequently, decisions of local judges remain impervious to international law.

In a subsequent case, Chocobar, ${ }^{208}$ the Court contemplated the constitutionality of post hoc changes in Argentina's social security program. While the Court admitted that certain international human rights provisions, now enjoying constitutional status, could potentially undermine the legality of the state's actions, ${ }^{209}$ it eschewed international law and instead rooted its decision in archaic Supreme Court decisions which interpreted the 1853 Constitution as granting the government carte blanche authority over the social security regime. ${ }^{210}$ The Court justified its reasoning -its disregard of international law in the name of domestic law-with Article 75(22) itself: none of the international human rights treaty provisions should "curtail the rights or guarantees

203. See "Bramajo, Hernán Javier," CSJN (1996) (copy on file with Author) (translations of the case are by the Author).

204. American Convention, supra note 44 , art. 7(5).

205. See "Bramajo," CSJN (1996), at 2. See also supra notes 193-95 and accompanying text.

206. See "Bramajo," CSJN (1996), at 2.

207. Id.

208. "Chocobar, Sixto C.," CSJN [1997-B] L.L. 240.

209. See id. at 243 (quoting Article 22 of the Universal Declaration, which guarantees all persons the "right to social security," and Article 26 of the American Convention, through which States parties promise to adopt internal measures that will further its economic obligations).

210. See "Chocobar," CSJN (1997), at 243-44. 
provided for in the Constitution . . . and should be understood as complementing the rights and guarantees provided for therein."211 The Court viewed its antedated decisions based on constitutional law as "rights or guarantees provided for in the Constitution," thus manipulating Article 75(22) to require international law to bow to these opinions. This formula-international human rights must harmonize with other constitutional rights, and the interpretation of those constitutional rights is governed by prior court decisions-creates a formidable and potent obstacle to the Court's exploration, activation, and unleashing of international human rights law. Chocobar's analysis allows the Court to remain a passive, if not an aberrant, transnational actor.

\section{b. Lower Court Decisions}

While a comprehensive review of post-1994 lower court decisions is beyond the scope of this Article, a representative survey from the lower federal courts based in Buenos Aires suggests that these courts are emulating the Supreme Court's passive approach. ${ }^{212}$ In general, judges recognized that the 1994 Constitution incorporates select human rights treaties. ${ }^{213}$ Most judges, however, merely listed international treaty provisions in conjunction with domestic statutes and decisions. ${ }^{214}$ Thus,

211. CONST. ARG. (1994) art. 75(22).

212. See, e.g., "Gonzalez, Juan Jose s/ if. ley 23.737," Buenos Aires, at 358 (Mar. 10, 1995) (myriad of criminal procedure violations, including forced confession outside presence of lawyer, illegal detention, and police brutality); "Astudillo Sanchez, Ramiro," Buenos Aires, at 442 (Mar. 22, 1995) (reasonable duration of imprisonment); "Pilade Fava L.M. s/ sobreseimiento," Buenos Aires (May 30, 1995) (imprisonment for repayment of debts); "Perasco, Luis C. s/ art. 1, ley 24.390," Buenos Aires (Feb. 13, 1996) (reasonable duration of imprisonment); "Blanco, R.A. s/ recusación," Buenos Aires, at 123 (Feb. 22, 1996) (right to impartial tribunal); "Bisbal de Haase, M. s/ cosa juzgada," Buenos Aires (Mar. 4, 1996) (protection from being placed in double jeopardy); "Furguielle, Silvio s/ sobreseimiento," Buenos Aires (Mar. 27, 1996) (reasonable length of pretrial detention); "Lescano, S.B. s/ nulidad," Buenos Aires (Aug. 22, 1996) (right to privacy, dignity of person, illegal search and seizure (vaginal drug searches)); "Paris, Alfredo Oscar s/ excarcelación," Olivos, at Part V (Nov. 1996) (preventative detention for sick detainee; right to health and right to be brought before a judge in reasonable time); "Cornador, Hernan Nicolas s/ internación," Olivos (Nov. 1996) (exploring constitutional rights of HIV-positive prisoners to special medical care); "Moreno Ocampo, L. s/ recusación," Buenos Aires, at 1498 (Nov. 22, 1996) (right to be adjudged before an impartial tribunal); "Cavallo, D.F. s/ excepción falta de acción y jurisdicción," Buenos Aires (Feb. 24, 1997) (right to equal protection before the law).

213. See, e.g., "Pilade Fava," Buenos Aires (May 30, 1995) (stating that the American Convention now has constitutional standing as a result of Article 75(22)); "Perasco," Buenos Aires (Feb. 13,1996) (noting that the International Covenant is incorporated into the Constitution via Article 75(22)); "Furguielle," Buenos Aires (Mar. 27, 1996) (the court must interpret the reasonableness of pretrial detentions pursuant to the Constitution, which now includes international treaties); "Lescano," Buenos Aires (Aug. 22, 1996) (noting that international treaties now have constitutional standing).

214. See, e.g., "Lescano," Buenos Aires (Aug. 22, 1996) (in case contesting the legality of vaginal searches for drugs, the court notes as relevant the right to be free from cruel, unusual and inhuman punishment and the right to personal dignity, listing, but not discussing the 
as with much Supreme Court jurisprudence, international law provides additional, although non-critical, legal support for the judge's conclusions. With rather terse, fleeting treatment of international law, it is no surprise that few judges embrace Giroldi and engage in any interpretative analysis of international human rights law or peruse international jurisprudence. ${ }^{215}$ This type of interpretation and analysis would undoubtedly and beneficially force judges to wrestle with international human rights law and mobilize the courts as fruitful transnational actors.

In merely listing international law along with domestic (constitutional and statutory) law, courts have not yet grappled with what it means for human rights treaties to have constitutional standing. Few judges differentiate human rights treaties' pre-1994 legal status from their post-1994 constitutional status, ${ }^{216}$ and they generally do not harness the elevated constitutional status of human rights treaties. Beyond rotely stating that some human rights treaties have constitutional standing pursuant to Article $75(22),{ }^{217}$ judges have not invoked their special constitutional status in reaching decisions. Thus, the analytical rhythm changes little in post-1994 decisions. The year 1994 did not represent some magically-disjunctive moment in terms of the courts' analytic style, approach, or potency. From a functional-legal perspective, constitutionalization has proved rather redundant in that courts are not using international treaties differently than they did under Ekmekdjián. ${ }^{218}$ The

substance of, select provisions of the American Convention and the International Covenant-ultimately resting its decision on domestic law); "Gonzalez," Buenos Aires (Mar. 10,1995 ) (in case implicating right to counsel of choice, the court cites relevant provisions of the American Convention and the International Covenant; however, the court merely lists international sources of law and uses them to cushion its conclusion, which rests on criminal procedure codes in domestic law).

215. Some cases actually defy Giroldi. For example, in a case concerning the reasonableness of a three-year delay in presenting a case to a judge, the court cites Article 7(5) of the American Convention (which reads "Any person detained shall be ... entitled to trial within a reasonable time or to be released without prejudice to the continuation of the proceedings"), yet the court looks toward domestic decisions for interpretive guidance in the face of compelling international jurisprudence. See "Furguielle," Buenos Aires (Mar. 27, 1996) (citing eight domestic decisions to interpret the meaning of "brought to trial within reasonable time"). Thus, the court flouts Giroldi's instructions to use international jurisprudence in deciphering international law.

216. See supra note 102-22 and accompanying text.

217. See "Bramajo," CSJN (1996), at 2. See also supra note 213 and accompanying text.

218. For example, in a pre-constitutional reform case dealing with the right to a translator, the court relied in part on Article 8(2) of the American Convention in ordering one. See "Khalil H. Dib s/ desig. intérprete," Buenos Aires (July 25, 1994); American Convention, supra note 44 , art. $8(2)$ (a) ("the right of the accused to be assisted without charge by a translator or interpreter, if he does not understand or does not speak the language of the tribunal or the court"). While the American Convention did not yet enjoy constitutional standing, Argentina's legislature had incorporated the American Convention into its statutory scheme, and the Supreme Court had endowed it with the ability to preempt conflicting statutes. See Law No. 23,054, Mar. 19, 1984 (copy on file with Author); "Ekmekdjián," CSJN (1992); supra notes 
lower courts, like the Supreme Court, are latent, if not impotent, transnational actors.

\section{Transnational Actors in Potential Conflict: Argentina's Legal System vs. Inter-American Human Rights System}

As transnational actors form "epistemic communities," their ability to reconstitute domestic interests to embrace an international norm increases exponentially. Argentina's internalization strategy failed to create an effective "epistemic community," not only because it failed to mobilize potential transnational actors, but also because it created competing rather than mutually-reinforcing relationships between two key transnational actors: Argentina's court system and the InterAmerican human rights system.

While the Argentine courts are not currently meeting their potential, ${ }^{219}$ they are the key domestic transnational actors and should serve as the crucial link between written, constitutional guarantees and the vindication of individual rights. They may invigorate human rights treaties and interpret international norms. They are, for all intents and purposes, the domestic "transmission belt,"220 carrying international human rights norms to an individual level and thus transporting international law to the most fundamental unit in domestic society.

The Inter-American human rights system is also an important transnational actor. When Argentina incorporated the American Convention into its Constitution, it imported not only the rights contained therein but also the system which the Convention consecrates. ${ }^{221}$ Argentina thus internalized and constitutionalized the entire regional system, comprised of an investigative/executive prong, the Inter-American Commission on Human Rights, and a judicial prong, the Inter-American Court of Human Rights. ${ }^{222}$ One of these now-

108-16 and accompanying text. Thus, prior to constitutional reform, the Convention also served as a viable source of law that could invalidate official action.

219. See supra notes 199 and accompanying text.

220. Koh, supra note 7, at 2651.

221. The American Convention may essentially be divided into two parts. Part I delineates rights, including civil and political rights (Chapter II, Articles 3-25) and economic, social and cultural rights (Chapter III, Articles 26-31). Part II constitutes the Inter-American institutions, including the Inter-American Commission on Human Rights (Chapter VII, Articles 34-51) and the Inter-American Court of Human Rights (Chapter VIII, Articles 52-73). See American Convention, supra note 44.

222. Once a "person or group of persons, or any non-governmental entity legally recognized in one or more member states," exhausts domestic remedies, meets the six month statute of limitations, and proves that the subject of the petition is not pending in another international proceeding, the Commission shall consider complaints of violations of the Convention by States Parties. American Convention, supra note 44, arts. 44, 46(1). Assuming that the petition is admissible, the Commission then investigates the allegations and issues a confidential report to the States Parties. See id. arts. 48, 50(1). Within three months following the issuance of the 
constitutionalized provisions requires that individuals seeking to vindicate rights before the Commission, and later the Court, exhaust domestic legal remedies, including the domestic court system. ${ }^{223}$ Thus, Argentina's Constitution, albeit through the appendage of the American Convention, contains a provision which requires petitioners to utilize the domestic court system completely before tapping the Inter-American system. Argentina's Constitution recasts the Inter-American Commission and Court as appellate-like tribunals, creating, in the words of one delegate, "a fourth and fifth" level of judicial review. ${ }^{224}$

This arrangement, with the Inter-American system constitutionally superimposed on the Argentine system like Russian stacking dolls, creates a zero-sum, highly-competitive relationship among these two transnational actors, undermining efforts to create a harmonious "epistemic community." Consider the following example. ${ }^{225}$ Argentine non-profit law grants organizations serving the "public good" tax-exempt status. A public interest group, representing the interests of homosexuals and lesbians, asserts that it is an organization serving the "public good"

preliminary report, the Commission must either: 1) decide that the matter has been rectified; 2) submit the case to the Inter-American Court of Human Rights; or 3) issue a final report which includes recommendations and may be published. See id. art. 51. See also Advisory Opinion OC-13/93, Inter-Am. C.H.R., ser. A, no. 13 (July 16, 1993).

If the Commission decides to submit the case to the Inter-American Court of Human Rights, it does so in a type of "solicitor general" capacity. The Court may only hear cases if the States Parties have agreed to its jurisdiction. See American Convention, supra note 44, art. 62. If the Court finds that a State Party violated the Convention, it may rule that "the injured party be ensured the enjoyment of his right" and may also receive "fair compensation." Id. art. 63(1). The Court may also adopt provisional measures, in "cases of extreme gravity and urgency." Id. art. 63(2).

See also Holly Dawn Jarmul, The Effect of Decisions of Regional Human Rights Tribunals on National Courts, 28 N.Y.U. INT'LL. \& POL. 311, 312-28 (1995-1996) (describing the Inter-American system); Thomas Buergenthal, The Inter-American System for the Protection of Human Rights, 1981 INTER-AM. Y.B. HUM. RTS. 80; Mary Caroline Parker, "Other Treaties": The Inter-American Court of Human Rights Defines its Advisory Jurisdiction, 33 AM. U. L. REV. 211(1983).

223. See American Convention, supra note 44, art. 46(1)(a) ("Admission by the Commission of a petition or communication ... shall be subject to the following requirements: a. that the remedies under domestic law have been pursued and exhausted in accordance with generally recognized principles of international law."). An applicant does not have to exhaust his remedies, however, if "(a) domestic legislation of the state concerned does not afford due process of law for the protection of the right or rights that have allegedly been violated; (b) the party alleging violation of his rights has been denied access to the remedies under domestic law or has been prevented from exhausting them; and (c) there has been an unwarranted delay in rendering a final judgment under the aforementioned remedies." Id. art. 46(2)(a).

See also Jarmul, supra note 222, at 315 (exhaustion requirement not strictly enforced where petitioner was not afforded due process, was denied access to domestic remedies, or was subject to an unwarranted delay).

224. See REC. CONST. ASSEMBLY No. 35, June 24, 1994, 5:30 P.M., at 1975 (statement of Alberto E. Balestrini).

225. This example is based on a live case. See "Comunidad Homosexual Argentina," CSJN 146 E.D. 228 (1991); "Comunidad Homosexual Argentina c/ Inspeción General de Justicia," CApel. CC, Buenos Aires (July 12, 1990) (copy on file with Author). 
and that it should be granted tax-exempt status. The District Court disagrees, arguing that an organization serving homosexual interests does not serve the "public good." The Civil Court of Appeals agrees with the District Court, and the Supreme Court upholds the decisions of the lower courts. All Argentine courts interpret the American Convention's guarantee of equal protection of the laws in reaching their decision. ${ }^{226}$ The public interest group then brings its case to the InterAmerican Commission, arguing that Argentina's denial of tax-exempt status discriminates on the basis of sexual orientation, thus violating the American Convention. The claim is admissible because the public interest group has exhausted all domestic remedies. ${ }^{227}$ The Commission issues a report that concludes that Argentina has violated the American Convention and asks Argentina to grant the petitioner-organization taxexempt status. ${ }^{228}$ Argentina does not respond to the Commission's report within the allotted time, ${ }^{229}$ and the Commission then decides to bring the case to the Inter-American Court. ${ }^{230}$ The Court hears the case and ultimately decides that Argentina did, indeed, violate the Convention by discriminating against the public interest group on the basis of sexual orientation.

Now what? If Argentina bends to accommodate the Inter-American Court's ruling, then it risks undermining the budding legitimacy of its own court system. As noted above, the domestic courts are the key transnational actors in Argentina's bid to internalize international law, and yet they have been notoriously weak, corrupt, and ineffective..$^{231}$

226. See American Convention, supra note 44, art. 24 ("All persons are equal before the law. Consequently, they are entitled, without discrimination, to equal protection of the law.").

227. See American Convention, supra note 44, art. 46(1)(a).

228. See id. art. 50(1).

229. See id. art. 51(1).

230. See id.

231. The Argentine court system has been deemed to lack independence and to be relatively corrupt. See Tim Dockery, The Rule of Law Over the Law of Rulers: The Treatment of De Facto Laws in Argentina, 19 FORDHAM INT'L L.J. 1578, 1633 n.538 (1996) (citing public opinion polls demonstrating that Argentine citizens believe that the judiciary is corrupt and lacks independence from the executive); Garro, supra note 29, at 1. See also William C. Banks \& Alejandro D. Carrio, Presidential Systems in Stress: Emergency Powers in Argentina and the United States, 15 MICH. J.INT'LL. 1, 37 (1993) (stating that the Argentine courts and Congress have done little to consolidate the rule of law in Argentina). See also generally Owen M. Fiss, The Limits of Judicial Independence, 25 U. MIAMI INTER-AM. L. REV. 57 (1993).

The 1994 bombing of a Jewish Community Center, killing ninety-nine people, provides a current example of an ineffective judiciary. See Kenneth J. Levit, Terrorism, Democracy and the Jews of Argentina, 22 HUM. RTS. 26, 1995. The investigation has proceeded at an extremely slow pace. See Katherine Ellison, Jewish Center Bombing Probe Fails to Get Results, Houston Chron., Dec. 15, 1995, at 27. Much evidence suggests that the Menem government itself, including the police, played a significant role in the bombing. See Sebastian Rotella, Argentine Police Held in '94 Blast, L.A. TIMES, Aug. 1, 1996, at A1. Despite weekly protests in front of the tribunales (courts), the courts have yet to conduct a meaningful, independent trial. Furthermore, violence against Jewish targets continues. See Calvin Sims, Jewish 
Concomitantly, the rule of law has been problematic. ${ }^{232}$ Most scholars agree that the rule of law and an independent judiciary are crucial to Argentina's attempt to fortify democracy, ${ }^{233}$ perhaps the most important bulwark in the protection of individual rights. How, then, can a country's highest court effectively consolidate the rule of law when another court second-guesses its decisions? How can a court system build legitimacy and fortify its public image when a competing court system says, "almost, but not quite right"? If domestic courts, particularly the Supreme Court, are to be effective "transmission belts," the public must perceive them as strong and legitimate. A contrary InterAmerican Court decision that Argentina grafts onto its domestic system, however, reveals the vulnerability of the courts and the potentially ephemeral nature of their decisions-hardly legitimating and fortifying attributes.

What if Argentina ignores the Inter-American Court decision and the Supreme Court's decision rests? While Argentine courts might earn legitimacy, this move would undermine the legitimacy of the InterAmerican system. It would also clash with efforts to consolidate the rule of law in Argentina itself. By virtue of the American Convention, the Inter-American human rights system is a part of the Constitution and the domestic legal fabric. ${ }^{234}$ Thus, a dismissal of an Inter-American Court decision is tantamount to a dismissal of the Argentine Constitution. As Argentina attempts to consolidate the rule of law-one of the weakest links being adherence to constitutional norms-it must attempt to abide by, rather than deviate from, its own Constitution.

Argentina's internalization strategy has created a classic zero-sum game between two transnational actors, the Argentine courts and the Inter-American human rights system. To legitimize the domestic courts' decisions is to denigrate the legitimacy of the Inter-American system. On the other hand, to enhance the credibility of the Inter-American Commission and Court decisions is to detract from Argentina's efforts to bolster the image of its judiciary, as well as efforts to use the new Constitution as a vehicle to consolidate the rule of law.

This conundrum was not inevitable. If Argentina had internalized the substantive rights contained in human rights treaties rather than the entire treaties, then it would have reserved primacy for Argentine

Cemetery is Desecrated in Argentina, the Third this Year, N.Y. TMmEs, Oct. 22, 1996, at A7.

232. See supra notes 164 and accompanying text.

233. For an in-depth look at the role of an independent judiciary in Argentina's transition to democracy, see the compendium of pieces in TRANSITION TO DEMOCRACY IN LATIN AMERICA: THE ROLE OF THE JUdICIARY (Irwin P. Stotzky ed., 1993). See also Stotzky, supra note 164 and accompanying text; Fiss, The Limits of Judicial Independence, supra note 231 and accompanying text; Carlos Santiago Nino, Transition to Democracy, Corporation, and Constitutional Reform in Latin America, 44 U. MIAMI L. REV. 129 (1989).

234. See supra notes 221-24 and accompanying text. 
courts. ${ }^{235}$ For the Constitutional Assembly, however, human rights treaties were hermetically-sealed, inseparable packages. ${ }^{236}$ Instead, Argentina's Constitution now identifies two supreme arbiters of the law: the Supreme Court, as provided for in Article 116 of the Constitution ${ }^{237}$ and, via the conduit of Article 75(22), the Inter-American Court, whose jurisdiction rests on the exhaustion of domestic remedies ${ }^{238}$ and whose decisions are binding on States Parties. ${ }^{239}$ Wholesale constitutionalization of the Inter-American system, as well as the rights contained in the American Convention, created this tug-of-war between the Argentine judiciary and the Inter-American Court.

In spite of its apparent commitment to the treaty-as-packagewholesale-incorporation process, the Constitutional Assembly could have anticipated the dilemma it was creating and neutralized this competitive, zero-sum relationship through artful drafting. However, only one delegate recognized the potential for competitive conflict between the Argentine judiciary and the Inter-American human rights system; $; 40$ and a few other delegates recognized that by virtue of the constitutional amendments, Argentina was importing a new juridical system into its Constitution. ${ }^{241}$ By stating that human rights treaties may

235. Prior to Argentina's constitutionalization of the American Convention, it was not clear what the domestic juridical effect of Inter-American Court decisions would be. While the American Convention provides that "[t]he States Parties to the Convention undertake to comply with the judgment of the Court in any case to which they are parties," there are no formal InterAmerican mechanisms to ensure that States Parties enforce decisions. American Convention, supra note 44, art. 68(1). See also Jarmul, supra note 222, at 317. Nonetheless, political pressure from the Commission, the Organization of American States, or other countries frequently prods a country into compliance. See id. While States Parties assumed legal obligations vis-à-vis Article 68 of the American Convention, there was no practical enforcement mechanism other than political pressure. Furthermore, domestic courts, as opposed to legislatures or the executive, were not the primary compliance engines.

236. See supra notes $177-80$ and accompanying text. A few delegates made proposals which included the constitutionalization of rights (along the lines of the constitutions discussed supra notes 55-86) rather than the entire treaties themselves. See REC. CONST. ASSEMBLY NO. 10, June 9, 1994, 3:30 P.M., at 394 (statement of Marta N. Martino de Rubeo); REC. CONST. ASSEMBLY No. 26, June 23, 1994, 1:30 P.M., at 1255 (statement of Juan C. Hitters); REC. CONST. ASSEMBLY No. 28, June 23, 1994, 7:00 P.M., at 1438 (statement of María C. Vallejos). However, neither the Treaty Commission nor the Drafting Committee appeared to entertain these proposals seriously.

237. CONST. ARG. (1994) art. 116.

238. See supra note 223 and accompanying text.

239. See American Convention, supra note 44, art. 62.

240. See REC. CONST. ASSEMBLY No. 35, June 24, 1994, 5:30 P.M., at 1975 (statement of Alberto E. Balestrini) (recognizing that the Inter-American Court and Commission decide issues of law that will, by virtue of the constitutionalization of these institutions, stand above domestic constitutional decisions, thereby creating a fourth or fifth level of appeal).

241. See REC. Const. ASSEMBLY No. 19, June 17, 1994, 11:00 A.M., at 779 (statement of María N. Meana García, Pablo Verani, Horacio Massaccesi \& Santiago A. Hernandez) (international and regional courts will make juridical pronouncements); REC.CONST. ASSEMBLY No. 20, June 21, 1994, 1:00 A.M., at 832 (statement of María Bercoff) (individuals have the right to petition international and regional human rights systems to vindicate human rights); 
not curtail or limit enumerated rights, ${ }^{242}$ Article $75(22)$ clearly reveals that the Constitutional Assembly recognized the potential for conflict between substantive rights, as provided for in Titles I and II of the Constitution, and the panoply of substantive rights appended by virtue of constitutional incorporation of human rights treaties. ${ }^{243}$ Just as the Constitutional Assembly resolved substantive conflicts, it could have resolved more procedural conflicts by drafting a provision that addressed the tension. For example, the Constitution could have stated the following: "Supreme Court decisions, granting due regard to extant international juridical pronouncements, are final and non-reviewable by any supranational institution," or, alternatively, "Supreme Court decisions are presumptively final but subject to the ultimate jurisdiction of the Inter-American Court." While the former may not enhance the legitimacy of the Inter-American system and the latter may not enhance the legitimacy of the Supreme Court, either option would have defined their relationship and preempted competitive and potentially destructive vying for power. Either option would have also defined a rule of law: either Supreme Court decisions are final or they are subject to review. Thus, abiding by that rule would have helped consecrate and consolidate the rule of law in a society where lawlessness and anomie have been prevalent. ${ }^{244}$ Instead, we are left with two important transnational actors on a collision course.

\section{B. The Promises}

Percolating below the surface are some nascent reasons for optimism. Prodded by energetic NGOs, some judges are beginning to

REC. CONST. ASSEMBLy No. 20, June 21, 1994, 1:00. P.M., at 835 (statement of Ana M. Dressino) (human rights treaties, and their interpretation, should be subjected to the ultimate jurisdiction of supranational organizations); REC. CONST. ASSEMBLY NO. 22, June 22, 1994, 1:00 P.M., at 898 (statement of Juan F. Armagnague) (supranational organizations generate rules of law that Argentina must follow); REC. CONST. ASSEMBLY NO. 26, June 23, 1994, 1:30 P.M., at 1255 (statement of Juan C. Hitters) (recognizing that the Inter-American system has Commission and Court institutions and not only substantive rights).

242. CONST. ARG. (1994) art. 75(22) ("The rights granted in these treaties do not curtail the rights or guarantees provided for in the first part of the Constitution and should be understood as complementing the rights and guarantees provided for therein.").

243. Several delegates offered proposals regarding the potential conflict between written rights and appended rights. See REC. CONST. ASSEMBLY No. 17, June 15, 1994, 9:30 P.M., at 670 (statement of Cecilia Lipsyzc, Juan Schroeder, María Sanchez, Rina Leiva, Daniel García, Adriana Puiggrós \& Ana M. Pizzurno) (human rights treaties shall guide and condition the interpretation of domestic law); REC. CONST. ASSEMBLY No. 19, June 17, 1994, 11:00 A.M., at 779 (statement of María N. Meana García, Pablo Verani, Horacio Massaccesi \& Santiago A. Hernandez) (same); REC. CoNST. Assembly No. 26, June 23, 1994, 1:30 P.M., at 1255 (statement of Juan C. Hitters) (interpret the Constitution and internal law in conformity with the Universal Declaration and the American Convention); Rec. Const. Assembly No. 35, June 24, 1994; 5:30 P.M., at 1975 (statement of Alberto E. Balestrini) (same).

244. See supra notes 231-33 and accompanying text. 
embrace international human rights law as a primary, if not the primary, source of individual rights. International human rights treaties are also slowly trickling toward untouched segments of society, and Article 75(22) may have some latent allies.

\section{Unlikely Bedfellows: Potential Transnational Actors}

Argentina's human rights internalization strategy may have some unexpected, yet largely untapped allies. Apparently, the impetus for constitutionalization of human rights treaties was not a magnanimous desire to sanctify human rights or a desire to repent for a dark past; it was instead an outgrowth of regional integration and regional trading blocks-namely Mercosur-and Argentina's desire to be a welcome and powerful member of such blocs. ${ }^{245}$ In debate and public statements regarding Article 75(22), delegates incessantly referenced economic integration, and virtually all the delegates that spoke about the provision underscored its importance in terms of Mercosur and/or economic integration. For some delegates, sovereignty was the link: if sovereignty concerns had created resistance to human rights treaties and systems in the past, then Argentina's entrance into Mercosur, and its concomitant abdication of power to a supranational entity, neutralized these concerns. ${ }^{246}$ Other delegates believed that if Argentina was going to make an honest attempt to join the international community, its joining a regional trade bloc was insufficient-Argentina also needed to participate in a multitude of international organizations, including those that promoted human rights. ${ }^{247}$ As proof, many delegates referenced

245. See supra notes $173-76$ and accompanying text.

246. See REC. CONST. ASSEMBLY No. 20, June 21, 1994, 11:00 A.M., at 832 (statement of María Bercoff) (resigned to the fact that countries have ceded authority to supranational trading blocs, thus arguing that Argentina should not hesitate to cede authority in the human rights context); REC. CONST. ASSEMBLY No. 20, June 21, 1994, 11:00 A.M., at 835 (statement of Ana M. Dressino) (regional integration demonstrates that countries can legitimately transfer authority and sovereignty to supranational entities).

247. See REC. CONST. ASSEMBLY No. 16, June 15, 1994, 3:00 P.M., at 611 (statement of Jorge D. Amena, Susana S. de De María, María C. Allenano \& Augusto Acuña; REC. CONST. ASSEMBLY No. 19, June 17, 1994, 11:00 A.M., at 786 (statement of Guillermo E. Estevez Boero, Alfredo P. Bravo \& Norberto L. La Porta) (in order to take advantage and participate in regional integration, it is necessary to participate in international organizations and therefore give more than lip service to international norms, among the most prominent being the Universal Declaration and the subsequent development of regional human rights system); REC. CONST. AsSEMBL.Y No. 22, June 22, 1994, 1:00 P.M., at 898 (statement of Juan F. Armagnague) (discussing the European Union and the importance of creating international communities to nurture not only trade but also human rights); REC. CONST. ASSEMBLY NO. 24, June 22, 1994, 5:00 P.M., at 1013 (statement of Alberto A. Natale, Pablo A. Cardinale \& Carlos A. Caballero Martín) (also discussing European Union)); REC. CONST. ASSEMBLY NO. 26, June 23, 1994, 1:30 P.M., at 1255 (statement of Juan C. Hitters) (international integration treaties, human rights treaties, and in fact all international treaties are integrated components of a new international world order); REC. CONST. ASSEMBLY NO. 28, June 23, 1994, 7:00 P.M., at 1438 (statement of Maria C. Vallejos) (international integration is socio-economic, and thus, 
other countries who had constitutionally elevated the status of international human rights norms as part of a concerted effort to enhance the states' standing and prominence in the international community. ${ }^{248}$

The ultimate structure of Article 75 further illustrates the marriage between human rights and trading interests. Article 75 also provides the following: 1) Congress has the power to approve and disapprove of treaties regarding international/regional integration even if it involves delegating power to supranational entities; 2) these treaties enjoy a status superior to domestic law; and 3) approval of integration treaties with Latin American states only requires an absolute majority vote of both houses of the legislature. ${ }^{249}$ In fact, most members of the Constitutional Assembly that proposed language concerning incorporation of international human rights norms concurrently proposed language concerning the approval and status of treaties regarding integration. 250

Argentina must embrace human rights as well as regional trade); REC. CONST. ASSEMBLY No. 31, June 24, 1994, 12:00 P.M., at 1701(statement of Enrique de Vedia) (building an international community requires rising to certain international standards, namely fundamental human rights standards); REC. CONST. ASSEMBLY No. 33, June 24, 1994, 2:00 P.M., at 1840 (statement of Emilia I. Juañuk, Federico R. Puerta, Julio c. Humada \& José D. Fabio) ("It is absolutely necessary that communities join to create conditions favorable to the utilization of progress, to open markets, to find peaceful solutions to conflicts. All in all, to improve the basic living standard and the quality of life."); REC. CONST. ASSEMBLY No. 35, June 24, 1994, 5:30 P.M., at 1975 (statement of Alberto E. Balestrini) (building an international community requires protection of human rights).

248. See Rec. CONST. Assembly No. 17, June 15, 1994, 9:30 P.M., at 659-60 (statement of Marcelo Bassani) (focusing on regional integration and discussing the Constitutions of Uruguay, Brazil, Colombia, Paraguay; as well as European Union and the Treaty of Rome); REC. CONST. ASSEMBLY No. 19, June 17, 1994, 11:00 A.M., at 786 (statement of Guillermo E. Estevez Boero, Alfredo P. Bravo \& Norberto L. La Porta) (discussing Guatemala, Honduras, El Salvador, Panama, Costa Rica and Peru); REC. CONST. ASSEMBLY No. 21, June 21, 1994, 6:00 P.M., at 848 (statement of Nilda Romero) (discussing Spain, France, Germany, and Brazil); REC. CONST. ASSEMBLY No. 26, June 23, 1994, 1:30 P.M., at 1255 (statement of Juan C. Hitters) (discussing Spain and Portugal, as well as provinces); REC. CONST. ASSEMBLY No. 35, June 24, 1994, 5:30 P.M., at 1975 (statement of Alberto E. Balestrini) (discussing Italy, France, Germany); REC. CONST. ASSEMBLY No. 31, June 24, 1994, 12:00 P.M., at 1701 (statement of Enrique de Vedia) (discussing Germany, Spain, France, Italy and Belgium).

249. See CONST. ARG. (1994) art. 75(24) (Congress shall have the power to "approve or disapprove treaties regarding integration that delegate power and jurisdiction to supranational organizations, under conditions of equality and reciprocity and respecting the democratic order and human rights. These treaties shall have a status superior to domestic law. Approval of these treaties with Latin American countries shall only require an absolute majority of both houses of Congress .... The renouncement of these treaties will require the prior approval of an absolute majority of both houses of Congress.").

250. See the proposed constitutional provisions in REC. CONST. ASSEMBLYNo. 17, June 15, 1994, 9:30 P.M., at 654 (statement of Elisa M.A. Carrio); REC. CONST. ASSEMBLY No. 20, June 21, 1994, 11:00 A.M., at 832 (statement of María Bercoff); REC. CONST. ASSEMBLY No. 20, June 21, 1994, 11:00 A.M., at 835 (statement of Ana M. Dressino); REC. CONST. ASSEMBLYNo. 22, June 22, 1994, 1:00 P.M., at 898 (statement of Juan F. Armagnague); REC. CONST. ASSEMBLY No. 24, June 22, 1994, 5:00 P.M., at 1013 (statement of Alberto A. Natale, Pablo A. Cardinale \& Carlos A. Caballero Martín); REC. ConST. AsseMBLY No. 24, June 22, 1994, 5:00 P.M., at 1071 (statement of Juan M. Pedersoli, Olga C. Abraham \& Pascual A. Rampi); REC. CONST. ASSEMBLY NO. 25, June 22, 1994, 8:30 P.M., at 1138 (statement of Alicia Oliveira 
Human rights, international trade, and regional integration became a tightly knit package, and the Constitution reflects this interwoven relationship.

Those affiliated with trading interests and successful regional integration thus maintain a stake in the effective internalization of human right norms. As several delegates stated, Argentina's human rights record is a potent indicator of its ability to cooperate in regional economic relationships. ${ }^{251}$ Among the Argentine business community, therefore, Article 75(22) may find engaged members of its epistemic community.

\section{Mobilization of Key Transnational Actors: The NGOs}

While the Argentine court system's failure to embrace international human rights norms has stymied compliance efforts, its reaction to the legal changes may be a result of benign ignorance rather than informed malevolence. Courts may not understand how to utilize human rights treaties or how such treaties fit into the legal hierarchy. Fortunately, through briefs and memorials, some NGOs are engaging in an instructive dialogue with courts. ${ }^{252}$ In Argentina, NGOs played a prominent role in the 1970 s in publicizing and, ultimately, curtailing human rights abuses. ${ }^{253}$ Regarding enforcement of Article 75(22), the most active NGO is the Centro de Estudios Legales y Sociales (Center of Legal and Social Studies, or CELS). ${ }^{254}$ With the assistance of a Ford Foundation grant, the CELS is engaged in a campaign to educate judges and

\& Eugenio R. Zaffaroni); REC. CONST. ASSEMBLY No. 26, June 23, 1994, 1:30 P.M., at 1255 (statement of Juan C. Hitters); REC. CONST. AsSEMBLY No. 31, June 24, 1994, 12:00 P.M., at 1701 (statement of Enrique de Vedia); REC. CONST. ASSEMBLY No. 35, June 24, 1994, 5:30 P.M., at 1975 (statement of Alberto E. Balestrini).

A few members did not link human rights and integration in their proposals. See REC. CONST. ASSEMBLYNO. 17, June 15, 1994, 9:30 P.M., at 659-60 (statement of Marcelo Bassani); REC. CONST. ASSEMBLY No. 22, June 22, 1994, 1:00 P.M., at 88 (statement of Augusto J.M. Alasino); REC. CONST. ASSEMBLY No. 26, June 23, 1994, 1:30 P.M., at 1193 (statement of María S. Farías, Federico P. Russo \& Hebe A. Maruco); REC. CONST. ASSEMBLY No. 28, June 23, 1994, 7:00 P.M., at 1438 (statement of María C. Vallejos); REC. CONST. ASSEMBLY No. 33, June 24, 1994, 2:00 P.M., at 1840 (statement of Emilia I. Juañuk, Federico R. Puerta, Julio C. Humada \& José D. Fabio).

251. See supra notes $246-47$ and accompanying text.

252. For an excellent discussion of the importance of NGOs in enforcement of human rights norms, see Kathryn Sikkink, Human Rights, Principled Issue-Networks, and Sovereignty in Latin America, 47 INT'L ORG. 41 1, 415-23 (1993). See also generally NGOs, THE UNITED NATIONS, AND GLOBAL GovernANCE (Thomas G. Weiss \& Leon Gordenker eds., 1996).

253. See Sikkink, supra note 252, at 423-28; Sims, supra note 159, at A4.

254. The CELS is recognized as a leading human rights advocacy group and think tank. See Faiola, supra note 159, at A25; Briscoe, supra note 159, at 7; Friedland, supra note 159, at A15. 
practitioners regarding the post-1994 status of human rights treaties, highlighting their potency and import. ${ }^{255}$

It is one of CELS' self-professed missions to educate courts about "the State's international obligations," seeing as Argentina reaffirmed its commitment to "fulfill these obligations" during the 1994 constitutional reform process. ${ }^{256}$ Through briefs and other pleadings, the CELS describes at length the elevated status of international human rights law and implores courts to respect treaties and to harness their potential. For example, in a case challenging the constitutionality of denying an AIDS patient new "cocktail" drugs that have proven effective in combating the onslaught of the disease, CELS sought to employ international law in support of its case. Instead of merely listing international treaties along with domestic sources of law, however, as many courts do, ${ }^{257}$ the CELS engaged in a written lecture about the new status of international human rights law:

The constitutional status of human rights treaties is not designed only to complement the dogmatic part of the Constitution but rather, and necessarily, to condition the exercise of all public power, including the exercise of judicial power, to respect and guarantee these international instruments. Given the constitutional hierarchy granted to the human rights treaties, their violation constitutes not only an assumption of the State's international responsibilities but also a violation of Argentina's own Constitution. On an internal level, the failure to apply these treaties on the part of domestic tribunals could result in the adoption of arbitrary decisions by ignoring norms with constitutional status.

The domestic tribunals are the entities that can assure that all international obligations regarding human rights assumed by the State ... are entirely respected and guaranteed by other powerful entities within the State. According to one scholar, 'The state has the right to delegate the application and interpretation of treaties to the judicial power. Nonetheless, if the tribunals commit errors in their work or decide not to give

255. The project is referred to as Programa sobre Aplicación del Derecho Internacional de los Derechos Humanos por los Tribunales Locales (Programa DIDH) [Program Regarding the Application of International Human Rights Law by Local Courts].

256. Memorial en Derecho, en Calidad de Amici Curiae, del Centro de Estudios Legales y Sociales (CELS), y el Center for Justice and International Law (CEJIL) s/ Libertad de Expresión y Calumnias e Injurias a Funcionarios Públicos (amicus curiae brief submitted by CELS and CEJIL), "Eduardo G. Kimel," Buenos Aires (Mar. 1996) (translations by the Author).

257. See supra notes 200-01 and 213-18 and accompanying text. 
effect to the treaties, ... then, through their decisions, the

State violates the treaties. ${ }^{258}$

The CELS repeats this "lecture" frequently, reinforcing to courts their responsibilities and the import of breeding Argentine compliance with human rights law. 259

Some courts have internalized this message, regurgitating similar language in many of their opinions. For example, two judges who included in their opinions a discussion on the status of international treaties, chose language highly reminiscent of the CELS "lecture":

The constitutional status of human rights treaties conditions the exercise of all public power, including the exercise of judicial power, to respect and guarantee these instruments. If courts do not apply these treaties, it could signify the adoption of arbitrary decisions by ignoring norms with constitutional status. The courts carry the burden of assuring that all international obligations assumed by Argentina with regard to human rights, are entirely respected and guaranteed; if the tribunals commit errors in the application or interpretation of treaties, their decisions will impose on the State a violation of the same treaties and responsibility before the international community. ${ }^{260}$

Through crafted brief writing, the CELS is successfully educating judges. While these opinions represent only a few isolated examples, they may be cause for cautious optimism regarding the ability of courts, when guided, to harness human rights treaties' invigorated potential.

258. Acción de Amparo Contra Instituto de Servicios Sociales para Jubilados y Pensionados, (Martín Abregú \& Victor E. Cosarin, attorneys) (photocopy on file with Author) (quoting LORD MCNAIR, THE LAW OF TREATIES 346 (1961) (translations by the Author).

259. See Human Rights Watch/Americas \& Centro por la Justicia y el Derecho Internacional, Memorial en Derecho Amicus Curiae, "Mignone, Emilio F. s/ presentación," reprinted in 33 EL DERECHO 8834 (Sept. 14, 1995) (using identical language as that quoted above in explaining the status of international human rights treaties) (photocopy on file with Author); Centro de Estudios Legales y Sociales (CELS), Memorial sobre el Derecho Internacional de Los Derechos Humanos Relativo a las Condiciones de Detencion de Los Enfermos con HIV y a la Restrictividad con que Debe Aplicarse la Prision Preventiva, "Sterla, Silvia s/ Interrupción de la Prisión Preventiva" [hereinafter CELS MEMORIAL] (Sept. 1996) (using identical language as that quoted above in explaining the status of international human rights treaties) (photocopy on file with Author) (translations by the Author); Promueve Amparo, "Mariela Cecilia Viceconte" (Martín Abregú \& Victor Cosarin, attorneys) (same) (photocopy on file with Author); Promueve Demanda de Amparo, "Sofía Tiscornia" \& "Emilio Fermin Mignone" (Gastón Chillier \& Victor Cosarin, attorneys) (same) (photocopy on file with Author).

260. "Paris, Alfredo Oscar s/ excarcelación," Olivos, at V (Nov. 1996) (constitutionality of prison conditions for prisoner who is chronically ill) (translations of the case are by the Author). See also "Cornador, Hernan Nicolas s/ internación," Olivos, at I (Nov. 1996) (constitutionality of prison conditions for HIV positive prisoners) (translations of the case are by the Author). While this passage is a translation, the original Spanish version is a verbatim copy of the Spanish version cited supra note 258 and accompanying text. 
The CELS, however, is not merely conditioning judges by feeding useful language. It is also implicitly teaching judges how to improve the analytic depth of their opinions through the use of Giroldi-approved sources. ${ }^{261}$ For example, in a memorial concerning prison conditions, particularly those for prisoners who tested positive for $\mathrm{HIV},{ }^{262}$ the CELS cited the typical panoply of sources, including the International Covenant on Civil and Political Rights, ${ }^{263}$ the International Covenant on Economic, Social, and Political Rights, ${ }^{264}$ the Universal Declaration, ${ }^{265}$ and the American Convention on Human Rights. ${ }^{266}$ In addition, the CELS cites some "non-traditional," interpretive sources pursuant to Giroldi's admonition to employ international jurisprudence in aid of judicial interpretation: the Committee on Economic, Social and Cultural Rights, in interpreting the state's obligations with regard to the right to health; ${ }^{267}$ the UN Commission on Human Rights reports with regard to state obligations in the face of the AIDS epidemic ${ }^{268}$ and the European Commission on Human Rights and the Inter-American Commission on Human Rights with regard to the meaning of "inhumane treatment."269 These interpretive sources have seeped into the responsive judicial opinions, frequently mirroring the brief's citation and language. ${ }^{270}$ The CELS' mode of analysis, citing human rights treaties with constitutional standing and then exploring international jurisprudence as an interpretive aid, indisputably shaped the courts' analyses, lending variety and depth to the courts' opinions and instructing courts on the power of Giroldi. ${ }^{271}$

261. See supra notes $196-98$ and accompanying text.

262. See supra note 260 and accompanying text and infra note 273 and accompanying text.

263. See International Covenant, supra note 44.

264. See International Covenant on Economic, Social and Political Rights, supra note 44.

265. See Universal Declaration on Human Rights, supra note 44.

266. American Convention, supra note 44

267. See "Cornador," Olivos (Nov. 1996), at 8.

268. See id. at 10.

269. Id. at 17,20 .

270. For example, one judge cites the Committee on Economic, Social and Cultural Rights for the proposition that states' ratification of the Covenant on Economic, Social and Cultural Rights obliges States Parties to guarantee the right to health, in a non-discriminatory manner, to all, including those who are HIV-positive. See "Cornador," Olivos (Nov. 1996), at I. The CELS MEMORIAL states, "The Committee on Economic, Social and Cultural Rights, the organ charged with enforcing the Pact [the International Covenant on Economic, Social and Cultural Rights] ... imposes two obligations with immediate effect: first, states promise to guarantee that the pertinent rights will be exercised without any discrimination (Art. 2.2), logically including those who are HIV-positive. The second obligation having immediate effect is to adopt means to assure [the previous obligation], whether legislative, judicial, administrative, or of any other type." CELS MEMORIAL, supra note 259, at 8-9. See also "Paris," Olivos, (Nov. 1996) at I (in case about preventative detention for those who are ill, quoting the same language).

271. These interpretive sources are slowly finding their way into other opinions. A few judges have cited the U.N. Commission on Human Rights (see "Paris," Olivos (Nov. 1996), at VIII; "Comador," Olivos (Nov. 1996)), as well as the European Court on Human Rights (see "Moreno Ocampo, L." Buenos Aires (Nov. 22, 1996), at 1499. 
With courts enhancing their understanding of the constitutional status of human rights and their ability to employ varied interpretive sources, human rights law appears to be slowly assuming a more prominent role in judicial decisions, thus portending an increased and more efficient use of international human rights treaties. Whereas some courts passively enlisted international law to support conclusions following constitutional reform, ${ }^{272}$ a few courts, with the ostensible prompting of CELS, have begun to use international law as a primary decision-making engine. In two notable cases concerning health issues, one dealing with treatment for prisoners with $\mathrm{AIDS}^{273}$ and another dealing with the legality of preventative detention for those who are ill, ${ }^{274}$ as well as one case concerning recusal of a biased judge, ${ }^{275}$ the courts, while discussing domestic law, mobilized international norms as their primary analytic tool. With the prodding of dedicated and relentless NGOs, Argentine courts, in an isolated and haphazard manner, are becoming more active transnational actors. Time will tell whether the courts will drive Argentina to compliance and ultimate obedience.

\section{Empowering Transnational Actors: The Individual}

The constitutionalization of human rights treaties enhanced public access to international human rights norms. In Argentina, law is notoriously difficult to find. There is no Argentine form of Westlaw; there is no Argentine Lexis; there is no current, computerized access to Supreme Court decisions. The law library at the Universidad de Buenos

272. See supra notes $212-17$ and accompanying text.

273. In Cornador, the court addresses the constitutionality of prison conditions for prisoners with AIDS, ultimately concluding that certain prison conditions implicate several constitutional and statutory rights, including, but not limited to, the right to health (under the Universal Declaration and the International Covenant on Economic, Social and Cultural Rights); the right to personal integrity (under the International Covenant and the American Convention); and the right to humane treatment while detained (under the American Declaration on the Rights and Duties of Man). See "Cornador," Olivos (Nov. 1996), at 8.

274. In "Paris," the court explores the legality of preventative detention for prisoners who are chronically ill. The court concludes that preventative detention for such prisoners is illegal, ultimately resting its decision on two rights-the right to health and the right to be brought before a judge within a reasonable period of time-and concluding that the primary legal sources of these rights are the Universal Declaration, the International Covenant, the International Covenant on Economic, Social and Cultural Rights, and the American Convention. See "Paris," Olivos (Nov. 1996).

275. The court in Moreno Ocampo examined the denial of a request for judicial recusal. The appellant, Luis Moreno Ocampo, is a popular media personality who exposes corruption among politicians and members of the judiciary. In a case in which Moreno Ocampo was a party, he was assigned to a judge who had been a target of one of his exposes. The judge denied the motion to recuse, and Mr. Moreno Ocampo appealed. The court reversed the denial of the motion to recuse, reasoning that the judge denied Moreno Ocampo the right to an impartial tribunal, citing the American Convention, the American Declaration on the Rights and Duties of Man, and the International Covenant on Civil and Political Rights, as primary legal support. See "Moreno Ocampo, L." Buenos Aires (Nov. 22, 1996). 
Aires is little more than a card catalog. The private universities' collections are better, but do not closely approximate U.S. standards. To find the Supreme Court opinions discussed in this Article, the Author engaged in a multi-day, multi-step process that culminated at the Supreme Court itself. Even finding a courtroom in the maze labeled Los Tribunales is a herculean task. In a society where the search for the law is so cryptic, those who are not trained to access the law, or those who cannot afford to hire someone so trained, stand highly disenfranchisedunable to negotiate through the dense web of rights. ${ }^{276}$

The Argentine Constitution is one exception to this rule. Newsstands adorn the streets of Buenos Aires. Along with the papers, tabloids, Harlequin novels, and soap opera digests, many vendors sell a copy of the "Constitución de la Nación Argentina." As a result of Article 75(22), this popular copy of the Constitution now includes the following: the American Declaration on the Rights and Duties of Man; the American Convention on Human Rights; the Universal Declaration; the International Covenant on Economic, Social, and Political Rights; the International Covenant; the Convention on the Prevention and Sanction of the Crime of Genocide; the International Convention on the Elimination of all Forms of Racial Discrimination; the Convention on the Elimination of all Forms of Discrimination against Women; the Convention against Torture and other Forms of Cruel, Inhuman, and Degrading Punishment; and the Convention on the Rights of the Child. While the non-lawyer may not herself be able to vindicate her rights, the popularization and access-granting effect of constitutionalization enhances the non-lawyer's ability to identify and claim ownership of rights. Until a large coterie of public interest lawyers develops in Argentina, ${ }^{277}$ the common person's ability to vindicate human rights violations may be somewhat limited. Supply frequently follows demand, however, and the first step in creating demand for such a coterie is to grant a broader segment of the population access to their panoply of rights. The constitutionalization of human rights treaties, at a minimum, creates such access and thus empowers individuals as the ultimate beneficiaries of such rights.

276. For an enlightening discussion of public interest law in Argentina and the virtual disenfranchisement of individuals, see Martin F. Böhmer, On the Inexistence of Public Interest Law in Argentina, Address at Semiario de Latinoamerica sobre Temas Constitucionales (Aug. $17,1996)$ (copy on file with Author).

277. See id. 
V. IMPLICATIONS FOR TRANSNATIONAL LEGAL PROCESS: THE LIMTTS OF THE LAW

Argentina's experiment is young and dynamic. At the time of the writing of this Article, international human rights treaties continue to seep into the Argentine legal landscape. Just as courts, with the prodding of CELS, became more receptive to international law, other transnational actors may similarly ignite processes that breed compliance and, ultimately, obedience. Thus, any conclusions one may draw from the Argentine experience are necessarily premature. Nonetheless, the first round of lessons from Argentina's internalization of international lawits limits and its latent promises-may help countries craft more potent internalization strategies.

Argentina's experience demonstrates how to build an epistemic community that will effectively propel an internalization strategy.

Transnational actors are the constituents of epistemic communities. The number of transnational actors that support an internalization strategy, as well as their enthusiasm and mutual relationships, will determine the relative success or failure of such strategies.

In the Argentine case, the internalization strategy fell relatively flat because it did not engage, energize and create synergistic relationships among transnational actors. The Constitutional Assembly debated the incorporation of human rights treaties in rather generic, undifferentiated terms; in fact, most debate concerned regional economic integration, with human rights treaties a mere afterthought. Thus, the constitutionalization process failed to enlist numerous members of the human rights community. Constitutionalization ordained the Argentine courts as the transnational actors responsible for the vindication and protection of international human rights; yet, the courts, thus far, have been passive actors. Furthermore, incorporation of entire treaties-treaties which constitute regional human rights systems-created a competitive, zerosum relationship between the Argentine courts and the Inter-American human rights system. Rather than synergistically entering Article 75(22)'s epistemic community, the Argentine courts and the InterAmerican Commission and Court may vie, in a potentially counterproductive manner, to be the final arbiter of international human rights.

The glimmer-the incipient promise-in Argentina's internalization experiment may also be traced to the identity and enthusiasm of various transnational actors. By publicizing international human rights, Article 75(22) may transform the bearers of those rights-individuals-into transnational actors. While linking Article $75(22)$ to the creation of a fertile legal climate for regional economic integration effectively removed human rights from debate and discussion, it also created potential allies among the trade and business 
communities. Finally, the energy and enthusiasm of NGOs, who themselves are members of Article 75(22)'s epistemic community, are helping transform passive transnational actors- the courts-into active, energetic transnational actors. Both the problems and the promises in Argentina's internalization strategy suggest that a large coterie of energetic and cooperative transnational actors create the "transmission belt" necessary to propel nations not only toward compliance, but also toward obedience of international norms.

Furthermore, the nature of the internalization strategy may determine its ultimate effectiveness. In describing transnational legal process, Professor Koh notes that internalization may take place via legal, political or social means. ${ }^{278}$ Argentina's experience suggests that in countries where the rule of law and the judiciary have historically been weak, internalization must be multifaceted, including legal, political, and social strategies. On its face, Article 75(22), a constitutional amendment, is a prototypical example of legal internalization. It strives to harness law to drive internalization of international norms. Law, however, is one of the weaker Argentine institutions and, within law, the Constitution is perhaps the weakest. ${ }^{279}$ While a naked law, especially in a country like Argentina, will not significantly further obedience, it may animate political and social actors who, in turn, may further obedience. In antiseptically removing "human rights" from debate and effectively treating Article 75(22) as an afterthought-an appendage necessary to facilitate economic integration efforts-the members of the Constitutional Assembly missed an opportunity to transform much of the human rights community into effective social and political actors with a stake in successful internalization of human rights law. Legal internalization did not trigger concomitant social and political internalization processes. And law alone is rather hollow in Argentina. Argentina now faces a challenge: it must transform a legal gesture into concrete, programmatic change.

278. See supra notes $18-20$ and accompanying text.

279. See supra notes $164,231-33$ and accompanying text. 
Appendix

Table 2: Argentina's Constitutional Treatment of Human Rights: Past and Present ${ }^{280}$

\begin{tabular}{|c|c|c|c|}
\hline $\begin{array}{l}\text { International } \\
\text { Covenant }\end{array}$ & $\begin{array}{l}\text { American } \\
\text { Convention }\end{array}$ & $\begin{array}{l}\text { Argentina } \\
\text { (1953 \& amend.) }\end{array}$ & Argentina (1994) \\
\hline $\begin{array}{l}\text { Art. 1: Right to } \\
\text { self-determination }\end{array}$ & N/A & & \\
\hline $\begin{array}{l}\text { Art. 2: State } \\
\text { obligation to respect } \\
\text { the rights and } \\
\text { ensure the rights } \\
\text { "without distinction } \\
\text { of any kind, such as } \\
\text { race, colour, sex, } \\
\text { language, religion, } \\
\text { political or other } \\
\text { opinion, national or } \\
\text { social origin, } \\
\text { property, birth or } \\
\text { other status." }\end{array}$ & $\begin{array}{l}\text { Art. 1: Race, } \\
\text { color, sex, } \\
\text { language, religion, } \\
\text { political or other } \\
\text { opinion, national } \\
\text { or social origin, } \\
\text { property, birth or } \\
\text { any other social } \\
\text { distinction. }\end{array}$ & $\begin{array}{l}\text { Art. } 16 \\
\text { (Article } 16 \text { does not } \\
\text { list categories, } \\
\text { rather it merely } \\
\text { states "All its } \\
\text { inhabitants are } \\
\text { equal before the } \\
\text { law.") }\end{array}$ & $\begin{array}{l}\text { Art.16/Art.75(23) } \\
0 \\
\text { Art. 75(23) } \\
\text { (Guarantees equal } \\
\text { opportunity as } \\
\text { provided for in } \\
\text { international } \\
\text { treaties) }\end{array}$ \\
\hline $\begin{array}{l}\text { Art. 3: Equal rights } \\
\text { of men and women }\end{array}$ & $\begin{array}{l}\text { Art. 24: General } \\
\text { equal protection } \\
\text { clause with no } \\
\text { explicit reference } \\
\text { to sex } \\
\text { discrimination }\end{array}$ & & $\begin{array}{l}\text { Art. } 37 \\
\text { (Equal rights for } \\
\text { men and women to } \\
\text { hold political } \\
\text { office) }\end{array}$ \\
\hline
\end{tabular}

280. Table 2 compares Argentina's 1853 and 1994 Constitutions, and then compares both to the International Covenant and the American Convention. Column 1 delineates the rights in the International Covenant. Column 2 lists the analogous rights in the American Convention, noting, where appropriate, the differences between the two international instruments. Columns 3 and 4 compare the Argentine Constitutions to these instruments. If a constitutional provision is analogous to a provision in one of the international documents, the Table notes the article's number. Furthermore, the Table indicates whether the constitutional provision is similar to (0), less expansive in scope than $(-)$, or more expansive in scope than $(+)$, the international instruments. The Table indicates, in bold, those places where the 1994 Constitution enhances the rights provided for in the 1853 Constitution. 


\begin{tabular}{|c|c|c|c|}
\hline $\begin{array}{l}\text { International } \\
\text { Covenant }\end{array}$ & $\begin{array}{l}\text { American } \\
\text { Convention }\end{array}$ & $\begin{array}{l}\text { Argentina } \\
\text { (1953 \& amend.) }\end{array}$ & Argentina (1994) \\
\hline $\begin{array}{l}\text { Art. } 4^{281} \text { : Public } \\
\text { emergency allows } \\
\text { suspension of rights; } \\
\text { however no } \\
\text { derogation from } \\
\text { rights to life, } \\
\text { prohibition on } \\
\text { torture, slavery, } \\
\text { punishment for } \\
\text { contractual liability, } \\
\text { ex post facto laws, } \\
\text { recognition as a } \\
\text { person, and freedom } \\
\text { of thought \& } \\
\text { conscience }\end{array}$ & $\begin{array}{l}\text { Art. 27: Allows } \\
\text { derogation from } \\
\text { rights during times } \\
\text { of war, public } \\
\text { danger, or other } \\
\text { emergency. No } \\
\text { derogation from } \\
\text { the following: } \\
\text { right to juridical } \\
\text { personality; right } \\
\text { to life; rights to } \\
\text { human treatment; } \\
\text { prohibition on } \\
\text { slavery, ex post } \\
\text { facto laws; } \\
\text { freedom of } \\
\text { conscience; right } \\
\text { to family; right to } \\
\text { name; rights of } \\
\text { child; right to } \\
\text { nationality; right } \\
\text { to participate in } \\
\text { government }\end{array}$ & $\begin{array}{l}\text { Art. } 23 \\
\text { Art. } 29 \\
\text { (In event of internal } \\
\text { disorder, unlimited } \\
\text { power to suspend } \\
\text { Constitution to } \\
\text { arrest, but not } \\
\text { punish, individuals, } \\
\text { or transfer } \\
\text { individuals to } \\
\text { different part of } \\
\text { nation) }\end{array}$ & $\begin{array}{l}\text { Art. } 23 \\
\text { Art. } 29 \\
-/ 0 \\
\text { (Same, except } \\
\text { Congress cannot } \\
\text { confer upon } \\
\text { Executive } \\
\text { "extraordinary } \\
\text { powers" or "the } \\
\text { whole of public } \\
\text { authority" whereby } \\
\text { "lives, the honor, or } \\
\text { the property" of } \\
\text { Argentines shall be } \\
\text { affected) }\end{array}$ \\
\hline $\begin{array}{l}\text { Art. 6: Right to life; } \\
\text { death penalty only } \\
\text { for the most serious } \\
\text { crimes, right to } \\
\text { amnesty or pardon }\end{array}$ & Art. 4 & $\begin{array}{l}\text { Art. } 18 \\
\text { (No death penalty } \\
\text { for political crimes; } \\
\text { no explicit right to } \\
\text { life) }\end{array}$ & $\frac{\text { Art. } 18}{\text { (Same) }}$ \\
\hline $\begin{array}{l}\text { Art. 7: No one } \\
\text { subject to torture or } \\
\text { other cruel, } \\
\text { inhuman or } \\
\text { degrading treatment }\end{array}$ & Art. 5(2) & $\begin{array}{l}\text { Art. } 18 \\
\text { (No torture or } \\
\text { whipping) }\end{array}$ & $\begin{array}{l}\text { Art. } 18 \\
\text { (Same) }\end{array}$ \\
\hline $\begin{array}{l}\text { Art. 8: No slavery } \\
\text { or slave trade }\end{array}$ & $\begin{array}{l}\text { Art. 6: Includes } \\
\text { trafficking in } \\
\text { women }\end{array}$ & $\begin{array}{l}\text { Art. } 15 \\
0\end{array}$ & $\begin{array}{l}\text { Art. } 15 \\
0\end{array}$ \\
\hline
\end{tabular}

281. The state of emergency provisions are exceptions to the rights granted in international instruments and constitutions. Thus, a state of emergency provision that permits curtailment of many rights under many circumstances circumscribes fundamental rights. The more expansive the state of emergency provision, the less expansive other rights. Thus, a broad state of emergency provision that allows many derogations receives a " - ," while a narrower state of emergency provision that allows few derogations receives a " + ." 


\begin{tabular}{|c|c|c|c|}
\hline $\begin{array}{l}\text { International } \\
\text { Covenant }\end{array}$ & $\begin{array}{l}\text { American } \\
\text { Convention }\end{array}$ & $\begin{array}{l}\text { Argentina } \\
\text { (1953 \& amend.) }\end{array}$ & Argentina (1994) \\
\hline $\begin{array}{l}\text { Art. 9: Liberty and } \\
\text { security of the } \\
\text { person; no arbitrary } \\
\text { arrest; informed of } \\
\text { the charges and the } \\
\text { reason for the arrest; } \\
\text { prompt recourse to } \\
\text { judicial process; } \\
\text { right to go to court } \\
\text { to determine } \\
\text { lawfuness of } \\
\text { detention }\end{array}$ & Art. $7(1-6)$ & $\begin{array}{l}\text { Art. } 18 \\
\overline{\text { (Warrant) }}\end{array}$ & $\begin{array}{l}\text { Art. } 18 \text { (Warrant) } \\
\text { Art. } 43 \\
\text { (Habeas corpus) } \\
-\end{array}$ \\
\hline $\begin{array}{l}\text { Art. 10: All those } \\
\text { detained shall be } \\
\text { treated with } \\
\text { humanity; accused } \\
\text { shall be segregated } \\
\text { from convicted and } \\
\text { juveniles segregated } \\
\text { from adults; focus } \\
\text { will be on } \\
\text { rehabilitation and } \\
\text { reformation }\end{array}$ & Art. 5 & $\begin{array}{l}\text { Art. } 18 \\
\text { (Provides for clean } \\
\text { and safe prisons } \\
\text { designed for } \\
\text { security and not } \\
\text { punishment.) }\end{array}$ & $\begin{array}{l}\text { Art. } 18 \\
\text { (Same) }\end{array}$ \\
\hline $\begin{array}{l}\text { Art. 11: No one } \\
\text { imprisoned merely } \\
\text { because they cannot } \\
\text { pay debts }\end{array}$ & Art. $7(7)$ & & \\
\hline $\begin{array}{l}\text { Art. 12: Liberty to } \\
\text { move within a } \\
\text { country and to leave } \\
\text { the country, except } \\
\text { for restrictions } \\
\text { provided by law in } \\
\text { order to protect } \\
\text { national security, } \\
\text { public order, public } \\
\text { health, morals or the } \\
\text { rights and freedoms } \\
\text { of others; no one } \\
\text { arbitrarily denied } \\
\text { the right of entry to } \\
\text { own country }\end{array}$ & $\begin{array}{l}\text { Art. 22: Includes } \\
\text { right to asylum; } \\
\text { may restrict these } \\
\text { rights "to the } \\
\text { extent necessary in } \\
\text { a democratic } \\
\text { society to prevent } \\
\text { crime or to protect } \\
\text { national security, } \\
\text { public safety, } \\
\text { public order, } \\
\text { public morals, } \\
\text { public health, or } \\
\text { the rights or } \\
\text { freedoms of } \\
\text { others." }\end{array}$ & $\begin{array}{l}\text { Art. } 14 \\
\text { ("Entering, } \\
\text { remaining in, } \\
\text { traveling through } \\
\text { and leaving } \\
\text { Argentine } \\
\text { territory") }\end{array}$ & $\begin{array}{l}\text { Art. } 14 \\
\text { (Same) }\end{array}$ \\
\hline $\begin{array}{l}\text { Art. 13: Can only } \\
\text { expel an alien in } \\
\text { accordance with law } \\
\text { and alien shall be } \\
\text { able to express } \\
\text { reasons against } \\
\text { expulsion }\end{array}$ & Art. 22(6) & & \\
\hline
\end{tabular}




\begin{tabular}{|c|c|c|c|}
\hline $\begin{array}{l}\text { International } \\
\text { Covenant }\end{array}$ & $\begin{array}{l}\text { American } \\
\text { Convention }\end{array}$ & $\begin{array}{l}\text { Argentina } \\
\text { (1953 \& amend.) }\end{array}$ & Argentina (1994) \\
\hline $\begin{array}{l}\text { Art. 14: Core } \\
\text { criminal defendant } \\
\text { rights: equal before } \\
\text { the courts, } \\
\text { presumption of } \\
\text { innocence, } \\
\text { informed of the } \\
\text { nature of the charge, } \\
\text { adequate time to } \\
\text { prepare defense, } \\
\text { no undue delay, } \\
\text { tried in presence, } \\
\text { right to defense } \\
\text { lawyer and right to } \\
\text { have one appointed } \\
\text { by the court if } \\
\text { "interests of justice } \\
\text { so require," } \\
\text { cross examination, } \\
\text { free assistance of } \\
\text { interpreter, } \\
\text { protection from self- } \\
\text { incrimination, } \\
\text { prohibition against } \\
\text { double jeopardy, } \\
\text { right to appeal, } \\
\text { right to be } \\
\text { compensated if } \\
\text { illegally detained }\end{array}$ & $\begin{array}{l}\text { Art. 8: In } \\
\text { addition, } \\
\text { confession is only } \\
\text { valid if made } \\
\text { without coercion }\end{array}$ & $\begin{array}{l}\text { Art. } 18 \\
\text { (Right to trial } \\
\text { protection against } \\
\text { self-incrimination } \\
\text { right to defense) }\end{array}$ & $\frac{\text { Art. }}{{ }_{\text {(Same) }}}$ \\
\hline $\begin{array}{l}\text { Art. 15: } \\
\text { Prohibition on ex } \\
\text { post facto laws, } \\
\text { except if benefits } \\
\text { the defendant }\end{array}$ & Art. 9 & $\begin{array}{l}\text { Art. } 18 \\
\overline{\text { (Defendant does not }} \\
\text { receive benefit of } \\
\text { subsequent } \\
\text { favorable law) }\end{array}$ & $\begin{array}{l}\text { Art. } 18 \\
\text { (Same) }\end{array}$ \\
\hline $\begin{array}{l}\text { Art. 16: Everyone } \\
\text { has the right to } \\
\text { recognition as a } \\
\text { person }\end{array}$ & Art. 3 & & \\
\hline $\begin{array}{l}\text { Art. 17: No one } \\
\text { subjected to } \\
\text { arbitrary or } \\
\text { unlawful } \\
\text { interference with } \\
\text { privacy, family or } \\
\text { home }\end{array}$ & $\begin{array}{l}\text { Art. 11: Also } \\
\text { includes } \\
\text { correspondence } \\
\text { and unlawful } \\
\text { attacks on "honor } \\
\text { and reputation" }\end{array}$ & $\begin{array}{l}\text { Art. } 18 \\
0 \\
\text { (Home and personal } \\
\text { correspondence is } \\
\text { inviolable) }\end{array}$ & $\begin{array}{l}\text { Art. } 18 \\
0 \\
\text { (Same) }\end{array}$ \\
\hline
\end{tabular}




\begin{tabular}{|c|c|c|c|}
\hline $\begin{array}{l}\text { International } \\
\text { Covenant }\end{array}$ & $\begin{array}{l}\text { American } \\
\text { Convention }\end{array}$ & $\begin{array}{l}\text { Argentina } \\
\text { (1953 \& amend.) }\end{array}$ & Argentina (1994) \\
\hline $\begin{array}{l}\text { Art. 18: Freedom of } \\
\text { thought, conscience } \\
\text { and religion. Can } \\
\text { restrict right to } \\
\text { manifest religious } \\
\text { beliefs only as } \\
\text { necessary to protect } \\
\text { public safety, order, } \\
\text { health and morals or } \\
\text { fundamental rights }\end{array}$ & $\begin{array}{l}\text { Art. 12: } \\
\text { Conscience and } \\
\text { religion }\end{array}$ & $\begin{array}{l}\text { Art. } 14 \\
\overline{\text { (Right "to freely }} \\
\text { profess one's } \\
\text { creed") }\end{array}$ & $\frac{\text { Art. } 14}{\text { (Same) }}$ \\
\hline $\begin{array}{l}\text { Art. 19: Freedom of } \\
\text { expression \& right } \\
\text { to hold opinions. } \\
\text { Right to expression } \\
\text { may be restricted in } \\
\text { respect of the rights } \\
\text { or reputations of } \\
\text { others or for } \\
\text { protection of } \\
\text { national security or } \\
\text { public order or } \\
\text { public health or } \\
\text { morals }\end{array}$ & $\begin{array}{l}\text { Art. 13: Thought } \\
\text { and expression. } \\
\text { Also prohibits } \\
\text { prior censorship, } \\
\text { excluding } \\
\text { censorship aimed } \\
\text { at children; and } \\
\text { prohibits } \\
\text { government } \\
\text { manipulation of } \\
\text { radio waves }\end{array}$ & $\begin{array}{l}\text { Arts. } 14 \text { \& } 32 \\
\text { ("[T]o publish ideas } \\
\text { in the press without } \\
\text { prior censorship" \& } \\
\text { "Federal Congress } \\
\text { shall not enact laws } \\
\text { that restrict freedom } \\
\text { of the press or that } \\
\text { establish federal } \\
\text { jurisdiction over } \\
\text { it") }\end{array}$ & $\begin{array}{l}\text { Arts. } 14 \& 32 \\
\text { (Same) }\end{array}$ \\
\hline $\begin{array}{l}\text { Art. 20: } \\
\text { Prohibition on war } \\
\text { propaganda and } \\
\text { advocacy of racial, } \\
\text { national or religious } \\
\text { hate }\end{array}$ & Art. 13(5) & & \\
\hline $\begin{array}{l}\text { Art. 21: Right to } \\
\text { peaceful assembly, } \\
\text { restrictions in the } \\
\text { name of national } \\
\text { security, public } \\
\text { safety, public order } \\
\text { and the protection } \\
\text { of public health or } \\
\text { morals }\end{array}$ & Art. 15 & & \\
\hline $\begin{array}{l}\text { Art. 22: Freedom of } \\
\text { association and to } \\
\text { join trade/labor } \\
\text { unions; restrictions } \\
\text { in the name of } \\
\text { national security, } \\
\text { public safety, public } \\
\text { order and the } \\
\text { protection of public } \\
\text { health or morals }\end{array}$ & $\begin{array}{l}\text { Art. 16: Includes } \\
\text { restrictions on } \\
\text { police and armed } \\
\text { forces ability to } \\
\text { form associations }\end{array}$ & $\begin{array}{l}\text { Art. } 14 \text { (1957 } \\
\text { amend) } \\
-/ 0 \\
\text { ("[T]o associate for } \\
\text { useful ends" and } \\
\text { labor union rights) }\end{array}$ & $\begin{array}{l}\text { Art. } 14(1957 \\
\text { amend) } \\
\vec{C} / 0 \\
\text { (Same) }\end{array}$ \\
\hline
\end{tabular}




\begin{tabular}{|c|c|c|c|}
\hline $\begin{array}{l}\text { International } \\
\text { Covenant }\end{array}$ & $\begin{array}{l}\text { American } \\
\text { Convention }\end{array}$ & $\begin{array}{l}\text { Argentina } \\
\text { (1953 \& amend.) }\end{array}$ & Argentina (1994) \\
\hline $\begin{array}{l}\text { Art. 23: } \\
\text { Preeminence of the } \\
\text { family;,right to } \\
\text { marry; need consent } \\
\text { of spouses }\end{array}$ & Art. 17 & & \\
\hline $\begin{array}{l}\text { Art. 24: Basic } \\
\text { children's rights to } \\
\text { equal protection; } \\
\text { nationality; and } \\
\text { registration }\end{array}$ & $\begin{array}{l}\text { Art. 18: Right to a } \\
\text { name } \\
\text { Art. 19: Right to } \\
\text { legal protection } \\
\text { Art. 20: Right to } \\
\text { nationality } \\
\text { Art. 17(5): Equal } \\
\text { protection for } \\
\text { those born in and } \\
\text { out of wedlock }\end{array}$ & & $\begin{array}{l}\text { Art. } 75(23) \\
0 \\
\text { (Women \& children } \\
\text { rights) }\end{array}$ \\
\hline $\begin{array}{l}\text { Art. 25: Equal } \\
\text { opportunity to } \\
\text { partake in public } \\
\text { affairs and engage } \\
\text { in public service; } \\
\text { right to vote }\end{array}$ & $\begin{array}{l}\text { Art. 23: Specifies } \\
\text { that the law can } \\
\text { regulate rights } \\
\text { only in the name } \\
\text { of age, nationality, } \\
\text { residence, } \\
\text { education, civil \& } \\
\text { mental capacity }\end{array}$ & & $\begin{array}{l}\text { Art. } 37 \\
0\end{array}$ \\
\hline $\begin{array}{l}\text { Art. 26: Standard } \\
\text { equal protection } \\
\text { clause, including } \\
\text { same protected } \\
\text { classes as those } \\
\text { listed in Article } 2\end{array}$ & $\begin{array}{l}\text { Art. 24: Does not } \\
\text { list the protected } \\
\text { classes }\end{array}$ & Art. 16 & Art. 16 \\
\hline $\begin{array}{l}\text { Art. 27: Right of } \\
\text { ethnic or religious } \\
\text { minorities to enjoy } \\
\text { their culture and } \\
\text { group identity. }\end{array}$ & N/A & & $\begin{array}{l}\text { Art. 75(17) } \\
0\end{array}$ \\
\hline
\end{tabular}




\begin{tabular}{|c|c|c|c|c|}
\hline 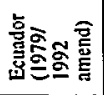 & $\stackrel{+}{\dot{\Sigma}}$ & $\frac{\widehat{a}}{\frac{\hat{n}}{\Sigma}}$ & $\frac{5}{50}$ & $\stackrel{\infty}{\stackrel{1}{*} !}$ \\
\hline 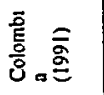 & & $\begin{array}{l}\frac{3}{\dot{\varepsilon}} \\
\frac{\dot{x}}{4}\end{array}$ & $\stackrel{F}{\stackrel{F}{*}+}$ & 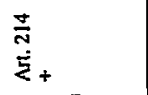 \\
\hline 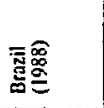 & $\begin{array}{l}\text { 言 } \\
\text { 产。 } \\
\text { to }\end{array}$ & $\overbrace{\bar{\Sigma}}^{\infty}$ & $\begin{array}{l}\text { 离 } \\
\text { 京。 }\end{array}$ & 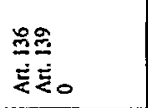 \\
\hline 弘 & & 胥 & & $\begin{array}{l}\bar{g} \\
\dot{\underline{x}}\end{array}$ \\
\hline 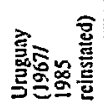 & & 趸 & & 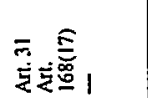 \\
\hline 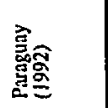 & & 妾 & $\stackrel{\infty}{\stackrel{\infty}{\dot{\Sigma}}+}$ & 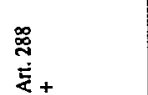 \\
\hline 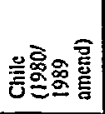 & & 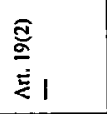 & & 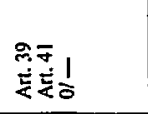 \\
\hline 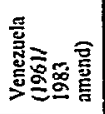 & & $\begin{array}{l}\vec{b} \\
\dot{\vec{E}}\end{array}$ & & 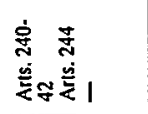 \\
\hline 量客。 & & $\begin{array}{l}8 \\
\stackrel{\dot{\Sigma}}{<0}\end{array}$ & & $\stackrel{\cong}{\underline{\dot{E}}}$ \\
\hline 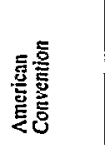 & $\underline{\mathbf{z}}$ & 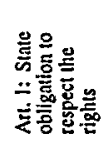 & 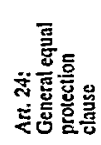 & 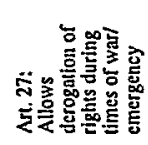 \\
\hline 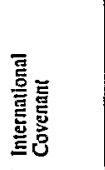 & 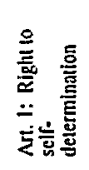 & 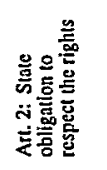 & 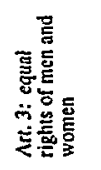 & 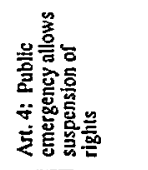 \\
\hline
\end{tabular}

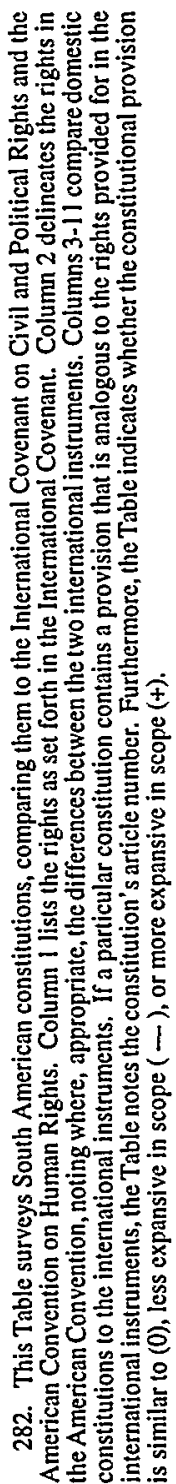




\begin{tabular}{|c|c|c|c|c|c|c|c|}
\hline 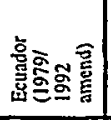 & 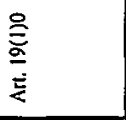 & 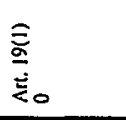 & 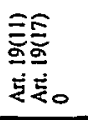 & 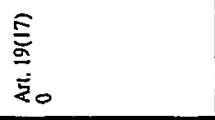 & & 完。 & 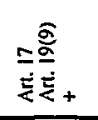 \\
\hline 产 & $=$ & E。 & 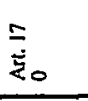 & 舟是! & & \begin{tabular}{l}
$\infty$ \\
\multirow{\Sigma}{*}{0} \\
\end{tabular} & 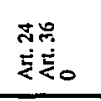 \\
\hline 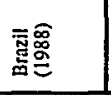 & 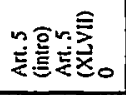 & 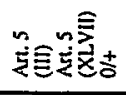 & 紋 & 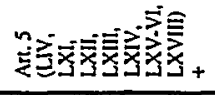 & 谙 & 䜌 & 站。 \\
\hline 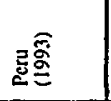 & 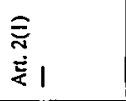 & 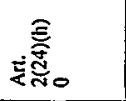 & 㺼 & 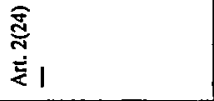 & & 䒺离 & 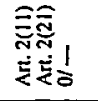 \\
\hline 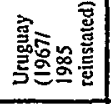 & 站芒。 & 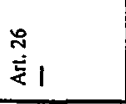 & & 家。 & 定 & ڤ̃ & F \\
\hline 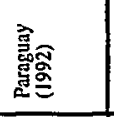 & 莣。 & n & 号 & 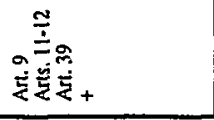 & $\begin{array}{l}\bar{N} \\
\stackrel{ \pm}{*}\end{array}$ & $\begin{array}{l}3 \\
\dot{\dot{x}_{0}}\end{array}$ & 焉安。 \\
\hline 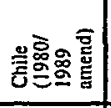 & 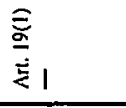 & & 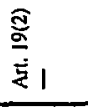 & 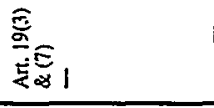 & 高 & & 高 \\
\hline 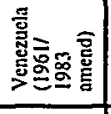 & 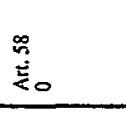 & 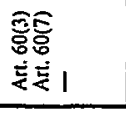 & & $\begin{array}{l}8 \\
\text { 芳1 } \\
\end{array}$ & & & 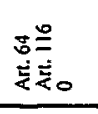 \\
\hline 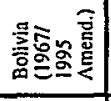 & 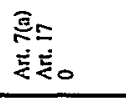 & $\begin{array}{l}\text { Na } \\
\text { to }\end{array}$ & 吕。 & 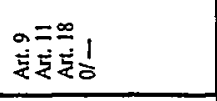 & & & 焉 \\
\hline 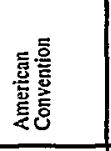 & $\stackrel{\overrightarrow{\dot{E}}}{\dot{\Sigma}}$ & 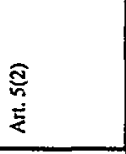 & 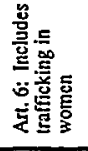 & 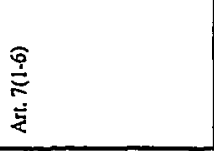 & n & 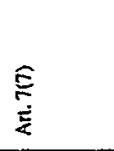 & 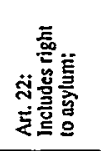 \\
\hline 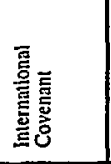 & 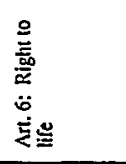 & 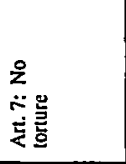 & 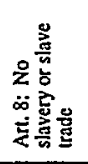 & 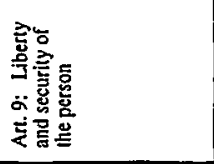 & 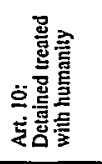 & 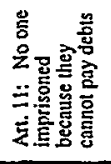 & 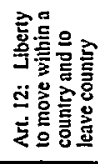 \\
\hline
\end{tabular}




\begin{tabular}{|c|c|c|c|c|c|c|}
\hline 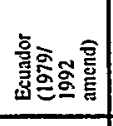 & & 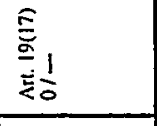 & 章 & & 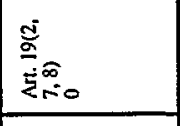 & 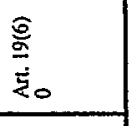 \\
\hline 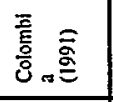 & 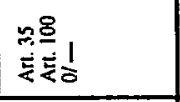 & 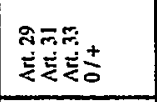 & $\begin{array}{l}\text { 荋 } \\
\end{array}$ & \begin{tabular}{|l} 
\pm \\
席。 \\
\end{tabular} & 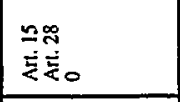 & 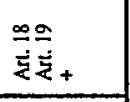 \\
\hline 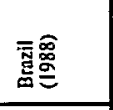 & 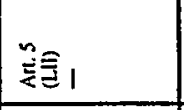 & 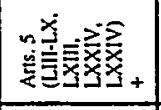 & 安新。 & & 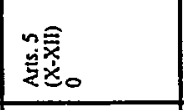 & 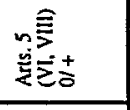 \\
\hline 롱영 & & 吾 & 䊿。 & & 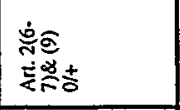 & 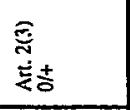 \\
\hline 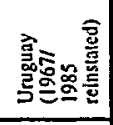 & & 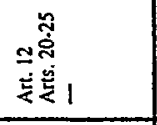 & & & 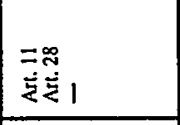 & \\
\hline 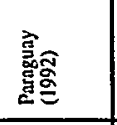 & 高立 & 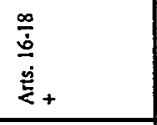 & 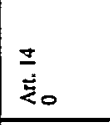 & & 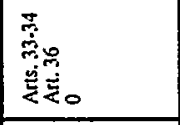 & 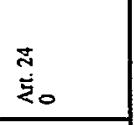 \\
\hline 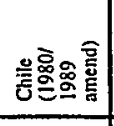 & & 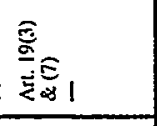 & \begin{tabular}{|l}
$\bar{E}$ \\
$\bar{\Phi}$ \\
$\overline{\bar{\Sigma}_{0}}$ \\
\end{tabular} & & 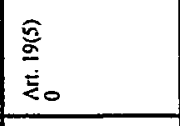 & $\begin{array}{l}\frac{6}{9} \\
\frac{5}{50} \\
\end{array}$ \\
\hline 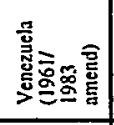 & & 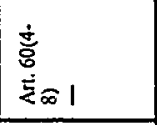 & 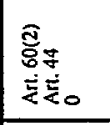 & & 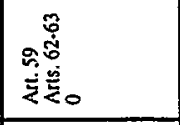 & 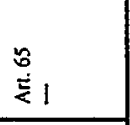 \\
\hline 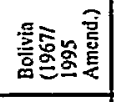 & & 送 & \begin{tabular}{|l|}
02 \\
安。 \\
\end{tabular} & & 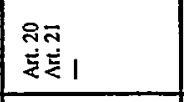 & 安 \\
\hline 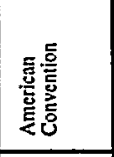 & 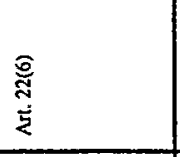 & 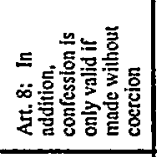 & $\begin{array}{l}\stackrel{0}{\dot{\Sigma}} \\
\end{array}$ & $\overline{\dot{z}}$ & 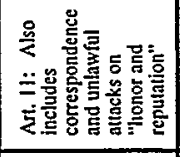 & 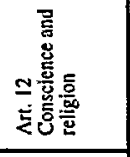 \\
\hline 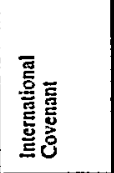 & 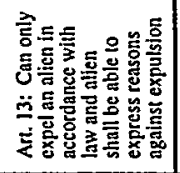 & 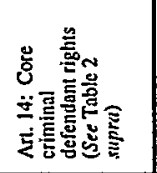 & 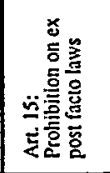 & 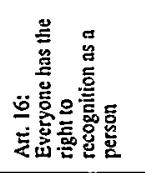 & 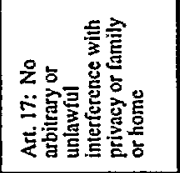 & 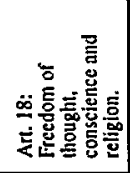 \\
\hline
\end{tabular}




\begin{tabular}{|c|c|c|c|c|c|c|}
\hline 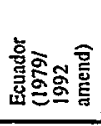 & 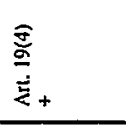 & & 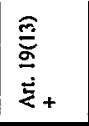 & 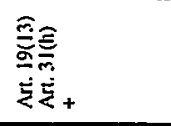 & 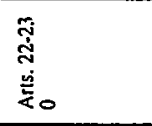 & 竎 \\
\hline 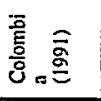 & 站. & & 芒走 & 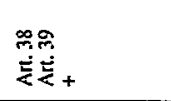 & $\stackrel{F}{\dot{\Sigma}}$ & $\frac{7}{7}$ \\
\hline 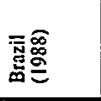 & 的文 & 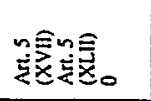 & 紋 & 安妾 & 芒 & $\begin{array}{l}\text { స̃ } \\
\stackrel{\Sigma}{\Sigma}\end{array}$ \\
\hline sa & 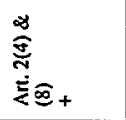 & & 㺼 & 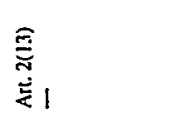 & & \\
\hline 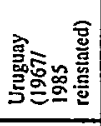 & $\begin{array}{l}\text { సे } \\
\text { हैo }\end{array}$ & & 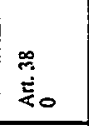 & श & 号 & $\begin{array}{l}1 \\
\frac{1}{3} \\
\frac{1}{2} \\
\frac{2}{2} \\
\end{array}$ \\
\hline 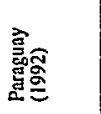 & 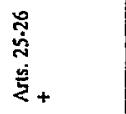 & & $\stackrel{\text { लू }}{\vec{\xi}+}$ & 站。 & 施言 & \\
\hline 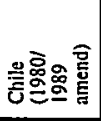 & $\frac{\widehat{\Xi}}{\frac{5}{5}}$ & & $\frac{E}{\underline{E}}$ & $\frac{\sqrt{a}}{\underline{a}}$ & $\overline{\dot{z}}$ & \\
\hline 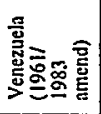 & 范 & 品 & $\underset{\dot{\xi}}{\overrightarrow{5}}$ & $\begin{array}{l}\text { R } \\
\text { 主 }\end{array}$ & 胥 & 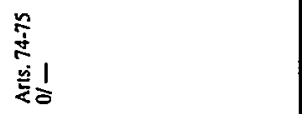 \\
\hline 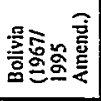 & 率 & & $\begin{array}{l}\bar{g} \\
\dot{\vec{x}} \mid\end{array}$ & 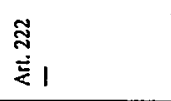 & $\begin{array}{l}\text { 品 } \\
\text { 安 } 1\end{array}$ & 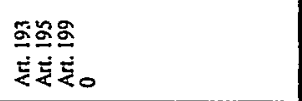 \\
\hline 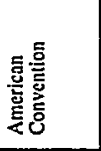 & 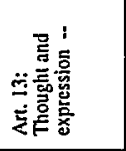 & 产 & $\frac{n}{\dot{z}}$ & 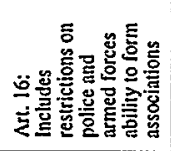 & $\stackrel{\overline{\dot{s}}}{\overline{\dot{z}}}$ & 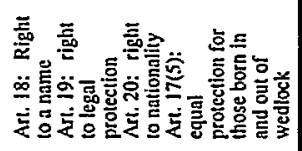 \\
\hline 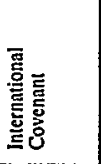 & 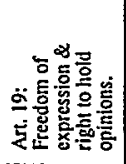 & 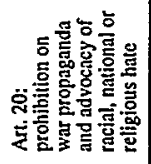 & 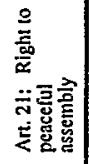 & 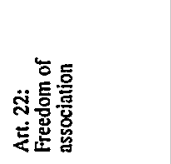 & 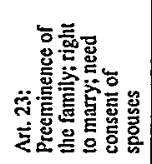 & 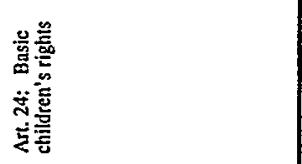 \\
\hline
\end{tabular}




\begin{tabular}{|c|c|c|c|}
\hline 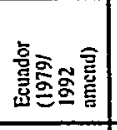 & 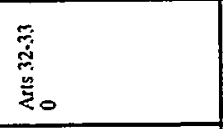 & 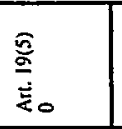 & 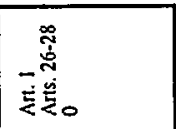 \\
\hline 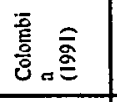 & 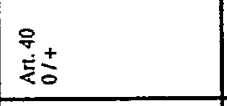 & 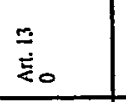 & \begin{tabular}{|l|} 
\\
要1 \\
\end{tabular} \\
\hline 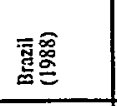 & 产 & 哹。 & 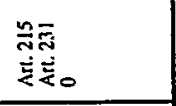 \\
\hline 吾产高 & 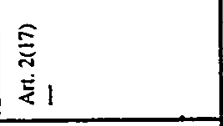 & 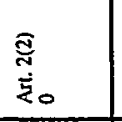 & $\begin{array}{l}\widehat{\widehat{a}} \\
\stackrel{\bar{\Xi}}{\dot{\Sigma}} \\
\end{array}$ \\
\hline 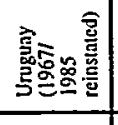 & $\begin{array}{l}\Sigma_{0} \\
\tilde{\Sigma}_{0} \\
\end{array}$ & $\begin{array}{l}\infty \\
\dot{1} \leq 1 \\
0\end{array}$ & \\
\hline 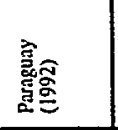 & 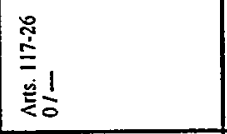 & 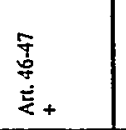 & 产。 \\
\hline 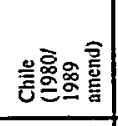 & 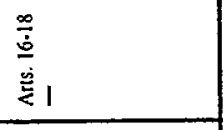 & $\begin{array}{l}\overline{\frac{5}{5}} \\
\frac{1}{5} \frac{1}{0} \\
\end{array}$ & \\
\hline 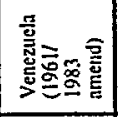 & 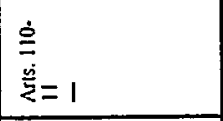 & 㐫 & \\
\hline 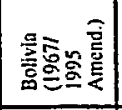 & 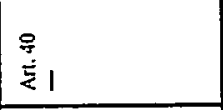 & 宰 & \\
\hline 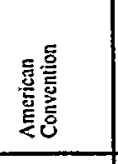 & 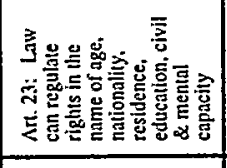 & 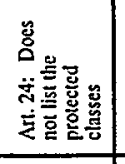 & $\frac{\underline{z}}{\mathbf{z}}$ \\
\hline 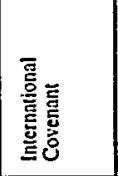 & 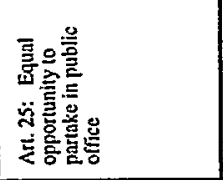 & 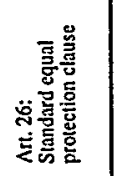 & 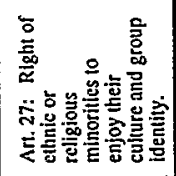 \\
\hline
\end{tabular}


<smiles>C1CCC1</smiles> 